

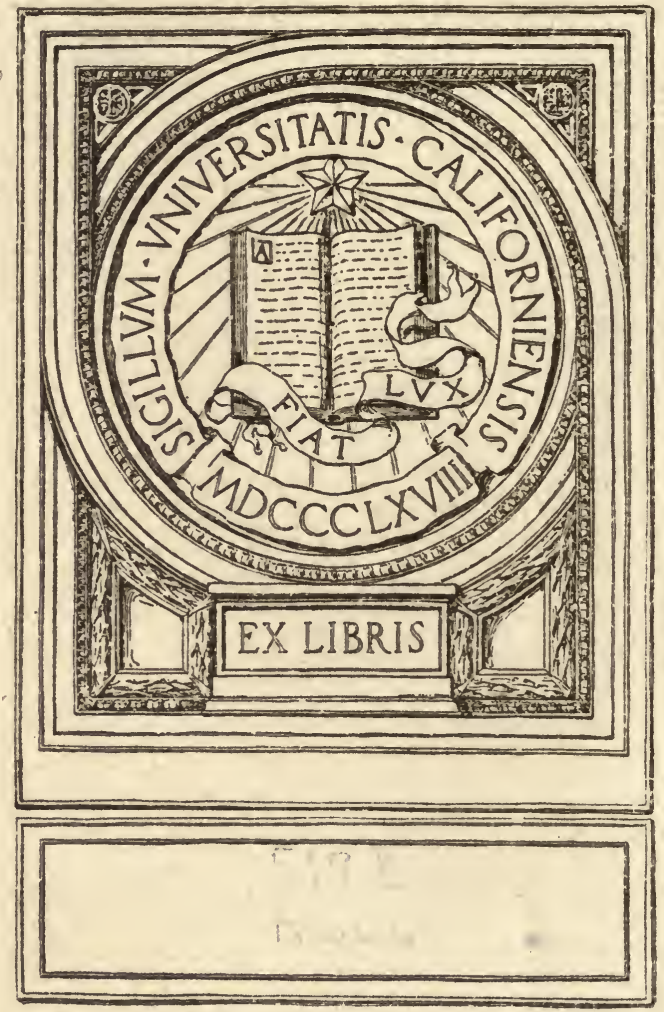


-

$-$

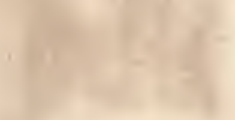
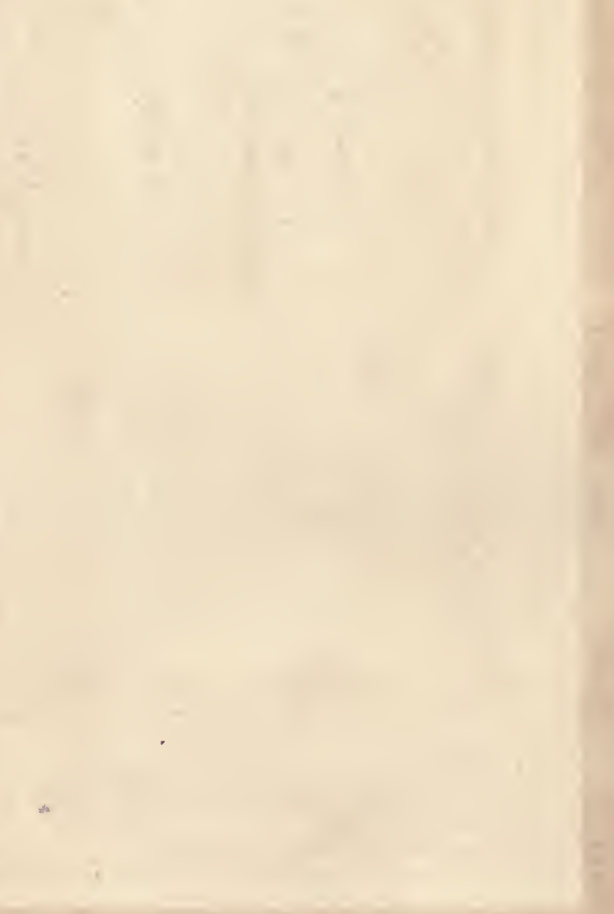

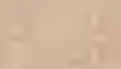

1

(x)

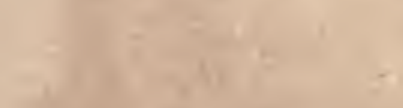
$=1$.

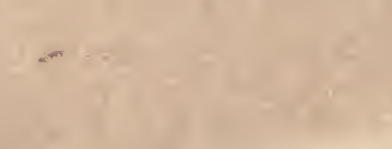





\section{THE GARDEN BEAUTIFUL}

\section{HOME WOODS AND HOME LANDSCAPE}


Principio arboribus varia est natura creandis:

Namque aliae, nullis hominum cogentibus, ipsae

Sponte sua veniunt, camposque et flumina late

Gurva tenent: ut molle siler, lentaeque genistae, Populus, et glauca canentia fronde salicta.

Pars autem posito surgunt de semine : ut altae

Castaneae, nemorumque Iovi quae maxima frondet

Aesculus, atque habitae Graiis oracula quercus.

Pullulat ab radice aliis densissima silva :

Ut cerasis ulmisque; etiam Parnasia laurus

Parva sub ingenti matris se subiicit umbra.

Hos natura modos primum dedit; his genus omne

Silvarum fruticumque viret nemorumque sacrorum.

VIRGIL, Georgicon, Liber Secundus.

Some trees under no compulsion from men, grow up of themselves, of their own accord, and spread widely over the plains and the winding river banks, like the pliant osier and the limber broom, the poplar, and the willow groves that look so hoary with their grey leaves. Some again spring up from the dropping of seed, like the tall chestnuts, and the forest-monarch which puts forth its royal leaves for Jove, the aesculus, and the oaks-in Greece deemed oracular. With others a forest of suckers shoots up from their roots, as with cherry-trees and elms-nay, the bay of Parnassus rears its infant head under the mighty covert of its mother's shade. These are the modes which Nature first gave to men unasked-to these the whole race of forest-trees and shrubs and sacred groves owe their verdure.-Conington. 


\section{THE}

\section{GARDEN BEAUTIFUL}

\section{HOME WOODS AND HOME LANDSCAPE}

\section{By W. ROBINSON}

AUTHOR OF THE 'WILD GARDEN': 'ENGLISH FLOWER GARDEN', ETC.

ILLUSTRATED WITH ENGRAVINGS ON WOOD

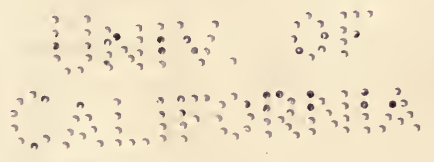

\section{LONDON}

JOHN MURRAY, ALBEMARLE STREET

1907 


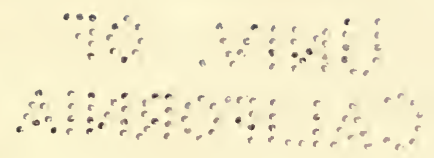

Oxford: Horace Hart
Printer to the University 


\section{PREFACE}

THIS book is for the country house, or any place where there is woodland, or land to plant; its object is to get people, after thought of the needs of a true garden, to think more of their woods from aesthetic and other points of view. Its aim is to teach the best of all lessons for garden-lovers-too often absorbed in the exotic, the curious, and the tender-that our own country's trees are the most beautiful we shall ever have, and our native flowers as fair as any. I do not mean any extension of the pleasure-ground, so often a poor 'sticky' thing, little better than the stereo. typed flower-garden, but the real woodland. Small gardens are often the most beautiful and the best for the happiness of their owners; but we have to think of the many who have greater opportunities, too seldom embraced-woodlands that are not brought into any happy relation with the house and are often not accessible from it. In the district in which I live there are hundreds of acres of. beautiful woods never seen by any but the gamekeeper, woods sheeted with Kingcups, Primroses, and Wood Hyacinths, more beautiful in their effect than any garden.

These woodland gardens rarely depend on the 
weather, and while Carnations and Roses in the garden may fail through weather and other causes, the woodland flowers are always true to their seasons, and no garden effect can equal theirs in breadth and in succession of beauty over the same ground. With their soft background of underwood it is vain for the gardener to attempt to rival them. During our winters no real flower-gardening is possible in these islands, save in favoured spots near the coast, and even the scared little conifers stuck out in the flower. beds (as before the King's palace in St. James's Park last winter) do not help us. Yet our climate is excellent for the hardy evergreen trees of the north, which give us shelter, warmth, and dignity; and no country of Europe is more favourable to such life than ours. It is not the 'pleasure-ground' but the woodland which enables us to grow fine trees, and their place is the wood and not the pleasure-garden. How seldom 'pinetums' or botanic gardens in Eng. land and France contain a well-grown Pine! The whole system of dotting trees on grass is a wrong one; the true way to enjoy their beauty and favour their growth is in woodland planting. Those who have no woods, but have bare lands to plant, can raise woods in ten years if they keep out cows, horses, rabbits, and hares for seven years. 
Other reasons for taking to the woods are, that there we at least get away from the vain though harmful talk about 'styles' with which most books on garden design are filled. We also part with the new and foolish teaching of the forestry books, separating tree-culture into two branches-arboriculture and sylviculture. If we go into a real wood anywhere we may soon see that true beauty is there and vigour too. Much wealth has been wasted in our islands in planting Pines in pinetums and pleasure-grounds where they never show their true character nor even grow well, in spite of often costly and needless preparation of soil.

In the free woodland weeding or routine of any kind need not trouble us; and there we may easily naturalize good native plants not already to be found there, or the finer woodland plants of other countries (Narcissus, Snowdrops, blue Windflower) and native plants not found in our district (Royal Fern, the Snowflake, and Lily of the Valley).

The open, airy, and well-considered ways I plead for are not against our woodland work in any way. The finest trees are often found at the sides of rides, their roots occupying all the ground; and such rides are best for hunting, shooting, riding, walking, and every use or pleasure to which woodland can be put. 
The words 'Home landscape' in the title lead to the idea that all of the work suggested in the book may be done with benefit to the general effect of the landscape. Two chapters from the 'English Flower Garden' are added with the view of making clear the essentials of garden design and planting, as if we endure a lifeless garden within view of the windows we are not likely to get to the fairest of all gardens, the Woodland garden. The hard and ugly lines so often seen about country houses, and which often come from modern ways of fencing and stereotyped plans, have no good reason to be. The artistic eye soon finds them out, and the artist will get out of their way. The only true test of all such things is the artistic one-Do they make for ugliness or for beauty? Breaking into the woods in the way I plead for here gives us many chances of improving the home landscape and opening out views -often airy stretches - into new country, even the rides through a foreground of young woods becoming a fine feature. For the rest, every idea that the book suggests $I$ have proved the good of myself.

$$
W . R \text {. }
$$

Gravetye Manor,

Primrose time, 1907. 


\section{CONTENTS}

CHAPTER I

Garden Design and Recent Writings upon it . . I

\section{CHAPTER II}

Art in relation to Flower Gardening and Garden DESIGN . • . • . • . • • . I6

CHAPTER III

Home Woods • • • • • • . • • 23

\section{CHAPTER IV}

The Greater Evergreen Trees of the Northern FOREST . . . . . . . . . . 36

\section{CHAPTER V}

The Greater Summer-Leafing Trees of the Northern FOREST . . • . . . . . . 50

\section{CHAPTER VI}

Native and European Trees best for our Islands 77

CHAPTER VII

Wood and Covert from Seed $\quad$ • $\quad$ • $\quad$ 82

\section{CHAPTER VIII}

Evergreen Covert ..$\quad \cdot \quad \cdot \quad \cdot \quad \cdot \quad \cdot \quad$. 88 
CHAPTER $\mathrm{X}$

Of MrXed Woods

CHAPTER XI

Forming Woodland Rides

\section{CHAPTER XII}

Water-side Planting

\section{CHAPTER XIII}

Shore-lands Planting

II2

CHAPTER XIV

Mountain and Hili and Down Planting . . . il6

CHAPTER XV

Woodland Fine in Colour . . . . . . . 123

CHAPTER XVI

Avoidable Waste in Planting . . . . . I3I

CHAPTER XVII

The Woodland Garden

CHAPTER XVIII

FENCING FOR WOOdLAND

CHAPTER XIX

THINNING Woods 
Contents

CHAPTER XX

PAGE

Grafting and its Effects on Trees . . . . 149

CHAPTER XXI

English Names for Trees $. \quad . \quad . \quad . \quad . \quad$. 153

CHAPTER XXII

National and Public Parks and Tree Planting • 157

CHAPTER XXIII

Home Landscape • . . . . . . . .

$\operatorname{INDEX} \quad \cdot \quad \cdot \quad \cdot \quad \cdot \quad \cdot \quad \cdot \quad \cdot \quad$ - $\quad$ - 72 


\section{LIST OF ILLUSTRATIONS}

Spruce Wood, Gloucestershire - . To face page 30 Corsican Pines, Rightly grown . . " " 38 The Swiss Pine (P. Cembra) at home . " " 44 A Group of Chestnuts, Bicton, Devon . " , " 66 Native Trees best : Sycamores at Taymouth Castle . . . . " , " 78

Evergreen Waterside Covert, Sussex . " " " 92 Woodland Ride . • • . . . " " " IO4 Waterside Planting, Sussex . . . " " 108 


\section{THE}

\section{GARDEN BEAUTIFUL}

\section{CHAPTER I}

\section{GARDEN DESIGN AND RECENT WRITINGS UPON IT}

OF all things made by man for his pleasure a flower garden has the least cause to be ugly, barren, or stereotyped, because in it we may have the fairest of the earth's children in a living, ever-changeful state, and not, as in other arts, mere representations of them. And yet we find in nearly every country place, pattern plans, conventional design, and the garden robbed of all life and grace by setting out flowers in geometric ways. A recent writer on garden design tells us that the gardener's knowledge is of no account, and that gardens

should never have been allowed to fall into the hands of the gardener or out of those of the architect; that it is an architectural matter, and should have been schemed at the same time and by the same hand as the house itself.

The chief error here is in saying that people, whom he calls 'landscapists', destroyed all the 'formal' gardens in England, and that they had their ruthless way until his coming. An extravagant statement, as must be clear to any one who takes the trouble to look into the thing itself, which many of these writers will not do nor regard the elementary facts of what they write about. Many of the most formal gardens in 
England have been made in Victorian days: the Crystal Palace, the Royal Horticultural Society's garden at Kensington, Shrubland, Witley Court, Castle Howard, Mentmore, Crewe Hall, Alton Towers, and many places in every county. During the whole of that period there was hardly a country seat laid out that was not marred by the idea of a garden as a conventional and patterned thing. So far from formal gardens being abolished, as the Irish peasant said of absentees, 'the country is full of them !' With Castle Howards, Trenthams, and Chatsworths staring at him, it is ludicrous to see a young architect weeping over their loss. Even when there is no money to waste in needless walls and gigantic water-squirts, the idea of the terrace is still carried out-often in plains, and in the shape of green banks piled one above the other, as if they were an artistic treat. There are hundreds of such gardens about the country, and the ugliest and most formally set out and planted gardens ever made in England were formed in Victorian days, when we are told by writers who do not look into the facts that all these things were lost.

It cannot be too clearly seen that 'formal' gardens of the most deplorable type are things of our own time, as it is only in our own time that the common idea that there is only one way of making a garden has been spread. Hence, in all the newer houses we see the stereotyped garden often made in spite of all the needs of the ground, whereas in old times it was not so, because in those days the stereotyped plans were not in every office and people had to think of the ground itself. Berkeley is not the same as Sutton, and Sutton is quite different from Haddon. 
Patterns of flowers and carpet-beds things of our own time. Moreover, on top of all this formality of design of our own day were grafted the most formal and inartistic ways of arranging flowers that ever came into the head of man, ways happily unknown to the Italians or the makers of the earliest terraced gardens. The true Italian gardens were often beautiful with trees in their natural forms; but bedding out, or marshalling the flowers in geometrical patterns, is entirely a thing of our own time, and 'carpet' gardening is simply a further remove in ugliness. The painted gravel gardens of Nesfield and Barry and other broken-brick gardeners were also attempts to get rid of the flowers and get rigid formality instead. Part of the garden architect's scheme was to forbid the growth of plants on walls, as at Shrubland, where, for many years, there were strict orders that the walls were not to have a flower or a creeper of any kind upon them. As these patterned gardens were made by persons often ignorant of gardening, and if planted in any human way with flowers would all 'go to pieces', the idea arose of setting them out as they appeared on the drawing-board, some of the beds not more than a foot in diameter, blue and yellow paints being used where the broken brick and stone did not give the desired colour!

Loss of old garden ways. With the adoption in most large and show places of the patterned garden, both in design and planting, disappeared almost everywhere the old English garden, that is, one with a variety of form of shrub and flower and even low trees; and now we only find this kind of garden here and there in Cornwall, Ireland, and Scotland, and on the outskirts of country towns. All true plant form was banished 
because it did not fit into the bad carpet pattern. All this can be seen to-day in the public gardens round London and Paris; even Kew, with the vast improvement of late years, has not emancipated itself from this ugly way of flower planting, as we see there, in front of the Palm-house, purple Beet marshalled in patterns and the whole laid out in imitation of the worst possible pattern of carpet. But we shall never see beautiful flower gardens again until natural ways of grouping flowers and variety of true form come back to us in the flower garden.

The wild garden does not take the place of the flower garden. After the central error above shown there comes a common one of these writers, of supposing that those who seek natural form and beauty in the garden and home landscape are opposed to the necessary level spaces about a house. I wrote the 'Wild Garden' to save, not to destroy, the flower garden; to show that we could have all the joy of spring in orchard, meadow or wood, lawn or grove, and to save the true flower garden near the house from being torn up twice a year to effect what is called spring and summer 'bedding'. The idea could be made clear to a child, and it is carried out in many places. Yet there is hardly a cobbler who rushes from his last to write a book on garden design who does not think that I want to bring the wilderness in at the windows, who have given all my days to save the flower garden from the ridiculous. A young lady who has been reading one of these bad books, seeing the square beds in my little south garden, says: 'Oh! why, you have a formal garden!' It is a small square embraced by walls, and I could not have used any other form to get the best use of the space. They are just the kind of beds made 
in like spaces by the gardeners of Nebuchadnezzar, judging by what evidence remains to us. He no more than I mistook bad carpets for flowers, but enjoyed vine and fig and flower as Heaven sent them. All this wearisome misunderstanding comes from writers not taking the trouble to grasp the simplest elements of what they write about.

The flower garden near the house is for the ceaseless care and culture of many and diverse things, often tender and in need of protection, in varied and artificial soils, staking, cleaning, trials of novelties, study of colour effects lasting many weeks, sowing and movings at all seasons. The wild garden, on the other hand, is for things that take care of themselves in the soil of the place, things which will endure for generations if we suit the plants to the soil, like Narcissi on a rich orchard bottom, or blue Anemone in a grove on the limestone in Ireland. The garden is a precious aid to the flower garden, inasmuch as it allows of our letting the flower garden do its best work because relieved of the intolerable needs of the 'bedding' system in digging up the garden twice a year.

Misuse of terms. Very often terms of gardening are misapplied, confusing the mind of the student, and the air is now full of the 'formal' garden. For ages gardens of simple form have been common without any one calling them 'formal' until our own time of too many words confusing thoughts. Seeing an announcement that there was a paper in the Studio on the 'Formal Garden in Scotland', I looked into it, seeking light, and found only plans of the usual approaches necessary for a country house, for kitchen, hall door, or carriage-way. We gardeners of another sort do not get in like the bats 
through the roof, but have also ways, usually level, to our doors, but we do not call them 'formal gardens'. There are gardens to which the term 'formal' might with some reason be applied. Here are a few words about such by one Percy Bysshe Shelley, whose clear eyes saw beauty if there was any to be seen in earth or sky:-

We saw the palace and gardens of Versailles full of statues, vases, fountains, and colonnades. In all that belongs essentially to a garden they are extraordinarily deficient.

A few more by Victor Hugo:-

There fountains gush from the petrified gods, only to stagnate; trees are forced to submit to the grotesque caprices of the shears and line. Natural beauty is everywhere contradicted, inverted, upset, destroyed.

And Robert Southey tells us of one

where the walks were sometimes of lighter or darker gravel, red or yellow sand, and, when such materials were at hand, pulverized coal and shells. The garden itself was a scrollwork cut very narrow, and the interstices filled with sand of different colours to imitate embroidery.

Such gardens may be called formal without too much disregard of language, and yet one might plant every one of them beautifully without in the least altering their outline. It is only where the plants of a garden are rigidly set out in geometrical design, as in carpet gardening and bedding out, that the term 'formal garden' is rightly applied.

We live in a time when men write about garden design unmeaning words or absolute nonsense; these are men who have had no actual contact with the work. They think garden design is a question that can be settled on a drawing-board, and have not the least idea that in any 
true sense the art is not possible without knowledge of many beautiful living things, and that the right planting of a country place is of tenfold greater importance than the ground-plan about the house.

In many books on garden design the authors misuse words and confuse ideas. Many, not satisfied with the good term, 'landscape gardener,' used by Loudon, Repton, and many other excellent men, call themselves 'landscape architects'-a stupid term of French origin implying the union of two absolutely distinct studies, one dealing with varied life in a thousand different kinds and the natural beauty of the earth, and the other with stones and bricks and their putting together. The training for either of these arts is wide apart from the training demanded for the other, and the earnest practice of one leaves no time, even if there were the genius, for the other.

Landscape gardening. The term 'landscape planting' is often scoffed at by these writers, yet it is a good one with a clear meaning, which is the grouping and growth of trees in natural forms as opposed to the universal aligning, clipping, and shearing of the Dutch; the natural incidence of light and shade and breadth as the true guide in all artistic planting. The term 'landscape gardening' is a true and, in the fullest sense, good English one, with a clear and even beautiful meaning, namely, the study of the forms of the earth, and frank acceptance of them as the best of all for purposes of beauty or use of planter or gardener, save where the surface is so steep that one must alter it to work upon it.

We accept the varied slopes of the river bank and the path of the river as not only better than those of a Dutch canal, but a hundred times better; and not only for their 
beauty, but for the story they tell of the earth herself in ages past. We gratefully take the lessons of Nature in her most beautiful aspects of vegetation-as to breadth, airy spaces, massing and grouping of the woods that fringe the valleys or garland the mountain rocks-as better beyond all that words can express than anything men can invent or ever have invented.

We love and prefer the divinely settled form of the tree or shrub or flower beyond any possible expression of man's misguided efforts with shears; such as we see illustrated in old Dutch books, where every living thing is clipped to conform to an idea of 'design' that arose in the minds of men to whom all trees were green things to be cut into ugly walls. We repudiate as false and ridiculous the common idea of the pattern book, that these aspirations of ours are in any way 'styles', the inventions of certain men, because we know that they are based on eternal truths of Nature, free as the clouds to any one who climbs the hills and has eyes to see.

The true test of a flower garden. The fact that ignorant men, who have never had the chance of learning these lessons, make pudding-like clumps in a vain attempt to diversify the surface of the ground, and other foolish things, does not in the least turn us aside from following the true and only ways to get the best expression possible of beauty from any given morsel of the earth's surface we have to plant. We sympathize with the landscape painter's work as reflecting for us, though often faintly, the wondrously varied beauty of the earth. We hold that the only true test of our efforts in planting or gardening is the picture. Do we frighten the artist away, or do we bring him to see a garden so free from ugly patterns and ugly colours that, seen in a beautiful light, it would be 
worth his seeing and perhaps painting? There is not, and there never can be, any other true test.

Even if our aim be right, the direction, as in many other matters, may be vitiated by stupidity, as in gardens where false lines and curves abound, as in the ChampsElysées in Paris. It is quite right to see the faults of this and to laugh at them; but how about those who plant in true and artistic ways? In Paris there is ceaseless and inartistic and vain throwing up of the ground, and sharp and ugly slopes, which are often against the cultivation of the things planted.

The rejection of clipped forms and book patterns of trees set out like lamp-posts, costly walls where none are wanted, and of all the too facile labours of the drawingboard 'artist' in gardens, first carried out in England, is set down by these writers on garden design as the wicked invention of certain men. No account has been taken of the eternally beautiful lessons of Nature or even the simple facts which should be known to all who write about such things. Thus in "The Art and Craft of Garden Making' we read:-

So far as the roads were concerned, Brown built up a theory that, as Nature abhorred a straight line, it was necessary to make roads curl about. Serpentine lines are said to be the lines of Nature, and therefore beyond question the only proper lines.

But nothing is said of the very important fact that in making paths or roads in diversified country it is often absolutely necessary to follow the line of easiest gradation, and this is often a beautiful bent line. In many cases we are not twenty paces from the level space around a house before we have to think of the lie of the ground in making walks, roads, or paths. We are soon 
face to face with the fact that the worst thing we can attempt is a straight line. If any one for any reason persists in the attempt the result is ugliness, and, in the case of drives, danger. Ages before Brown was born the roads of England often followed beautiful lines, and it would be just as true to attribute to Brown the invention of the forms of trees, hills, or clouds themselves, as to say that he invented the waved line for path or drive. The statement is of a piece with the other, that the natural and picturesque view of garden design and planting is the mischievous invention of certain men, and not the outcome of the most precious of all gifts, of Nature herself, and of the actual facts of tree and landscape beauty. All who have seen the pictures by the roadsides of many parts of Britain, and the paths over the hills, and, still more so, those who have to form roads or walks in diversified country, will best know the value of such statements.

$V$ ariety the true source of beauty in gardens. The very statement that there is but one way of making a garden is its own refutation; as with this formula before us what becomes of the wondrous variety of the earth and its forms, and of the advantages and needs of change that soil, site, climate, air, and view give us-plains, river valleys, old beach levels, mountains and gentle hills, chalk downs and rich loamy fields, forest and open country?

What is the use of Essex going into Dorset merely to see the same thing done in the home landscape or the garden? But if Essex were to study his own ground and do the best he could from his own knowledge of the spot, his neighbour might be glad to see his garden. We have too much of the stereotyped style already; in 
nine cases out of ten we can tell beforehand what we are going to see in a country place in the way of conventional garden design and planting; and clearly that is not art in any right sense of the word, and never can be.

As we go about our country the most depressing sign for all garden lovers (this often in districts of great natural beauty) is the stereotyped garden, probably made from an office book of plans. There is a belief in the virtue of paper plans which is misleading and only suits the wants of professionalism, and prevents the study of the ground itself, the only way to get the best result. Some of the new writers have no heart for the many beautiful things in the shape of trees and shrubs which have come to us during the past generation or two:-

A very few varieties of English trees are sufficient for all purposes, and we have yew for hedges, fine turf for a carpet, and quite enough flowers of brilliant hue that have always had a place in our gardens without importing curiosities from abroad.

Variety essential. Now if there is any clear fact about gardening it is that its charm often arises from variety, not necessarily botanical variety, but the difference between a Menabilly and the conventional garden essentially lies in a variety of trees, shrubs, and flowers. These writers need to be told that it is impossible to make a beautiful garden without the variety which they say is useless, not having, of course, any idea of the dignity and beauty of the trees of Japan, the Rocky Mountains, and northern Asia, or America.

One such writer says :-

It is no use spending money on gardeners and repairs, as it might be much better invested in architectural improvements or waterworks in the pleasure grounds. 
This is a stupid and harmful idea, as the two arts are in no way antagonistic but helpful rather. Take away all true planting and good gardening from our Castle Ashbys, Longleats, or Wiltons and what do we gain? For remember that the ground about a house, even slopes which must be terraced, is often very small in extent compared with the planting we may have to do in the home landscape.

But the ugly buildings that strew the land everywhere - Georgian, carpenter's Gothic, Victorian-if we take away the good planting, the one saving grace about them, there will be nothing left but an ugly pile to laugh at. Good building and good planting go so well together-one helping the other in every way-that it is odd to see any one writing on the subject without seeing that it is so. I cannot suppose that any good architect could fail to see the gain of good planting and good flower gardening in relation to his work. We have only the greatest satisfaction with a country place when both building and planting are good-a rare thing, unfortunately.

Any way good that best suits the site. To the good gardener all kinds of design are good if not against the site, soil, climate, or labours of his garden-a very important point the last. We frequently see beds a foot in diameter and many other frivolities of paper plans which prevent the labours of a garden being done with economy or simplicity. In many places where these hard-patterned gardens are carried out, they are soon seen to be so absurd that the owners quietly turf the spot over, and hence in many country places we see only grass where there ought to be a real flower garden. The good gardener is happy adorning old walls or necessary 
terraces, as at Haddon, as he knows walls are good friends in every way, both as backgrounds and shelters; but he is as happy in a lawn garden, in a rich valley soil, on the banks of a river, on those gentle hill-slopes that ask for no terraces, or in the hundreds of gardens in and near towns and cities of Europe that are enclosed by walls and where there is no room for landscape effect (many of them distinctly beautiful too, as in Mr. Fox's garden at Falmouth); as much at home in a Border castle garden as in the lovely Penjerrick, like a glimpse of a valley in some Pacific isle, or Mount Usher, cooled by mountain streams.

Waterworks garden design. The same architect turns to the waterworks as his chief solace:-

But of all the fascinating sources of effect in garden-making the most fascinating are waterworks. An expensive luxury as a rule, but they well repay the expense.

Well, there is some evidence of the sort of design these afford; some instances terrible in their ugliness (one hideous at Bayreuth). And with all the care that a rich State may take of them, can we say that the effect at Versailles is artistic or delightful? Water tumbling into the blazing streets of Roman cities and nobly designed fountains supplying the people with water was right ; but in our cool land artificial fountains are very different, and often a hideous extravagance. Of their ugliness there is evidence in nearly every city in Europe, including our own Trafalgar Square, and that fine (!) work at the head of the Serpentine. We have also our Crystal Palace and Chatsworth, designed as they might be by a theatrical super who had suddenly inherited a millionaire's fortune. What the effect of this is I need hardly say, but with all our British toleration of ugliness 
I have never heard anybody enthusiastic about their artistic merits. So far as our island countries go, nothing asks for more care and modest art than the introduction into the garden or home landscape of artificial water. Happily our countries are rich in the charms of natural water too often neglected in its planting.

Talk of the day about art. Among the great peoples of old was one supreme in art, from buildings chiselled as delicately as the petals of the wild Rose to their smallest coins and bits of baked clay in their graves, and this is clear to all men from what remains of their work gathered from the mud and dust of ages. And from that time of deathless beauty in art comes the voice of one who saw this lovely art in its fulness: The greatest and fairest things are done by Nature and the lesser by Art (Plato). There is not a garden in Britain, free from convention and carpet gardening, from the cottage gardens nestling beneath the Surrey hills to those fair and varied gardens in Cornwall, which does not tell the same story to all who have eyes to see and hearts to care for the thing itself. The only sad thing is that such words must be said again and again; but we live in a time of much printed fog about artistic things-the 'New Art' and the 'New Aesthetic'; 'Evolution,' which explains how everything comes from nothing and goes back again to worse than nothing ; the sliding bog of 'realism and idealism' in which the phrasemonger may dance around and say the same false thing ten times over; and, last and not least of all among these imbecilities, the teaching that to form a garden one had better know nothing of the things that should grow in it, from the Cedar of Lebanon to the Violets of the alpine rocks.

This teaching is as false as any spoken or written 
thing can be; there is an absolute difference between living gardens and conventional designs dealing with dead matter, be it brick or stone, glass, iron, or carpets. There is a difference in kind, and while any pupil in an architect's office will get out a drawing for the kind of garden we may see everywhere, the garden beautiful does not arise in that way. It is the difference between life and death we have to think of, and never to the end of time shall we get the garden beautiful formed or planted save by men who know something of the earth and its flowers, shrubs, and trees. I would much rather trust the first simple person, who knows his ground and loves his work, to get a beautiful result than any of those artificers. We have proof of this in the gardens of English people abroad that escape from the too facile plans of the office; far more beautiful gardens arise, as in the Isle of Madeira, where every garden differs from its neighbour and all are beautiful. So it is in a less degree in our islands, where the more we get out of the range of any one conventional idea for the garden the more beauty and freshness and happy incident we see. 


\section{CHAPTER II}

ART IN RELATION TO FLOWER GARDENING

AND GARDEN DESIGN

THERE is no reason why we should not have true art in the garden, and none why a garden should be ugly, bare, or conventional. The word 'art' being used in its highest sense here, it may perhaps be well to justify its use, and as good a definition of the word as any perhaps is 'power to see and give form to beautiful things', which we see shown in some of its finest forms in Greek sculpture and in the works of the great masters of painting.

But art is of many kinds, and owing to the confusion caused in many minds by the loose 'critical' talk of the day, it is not easy for all to see that true art is based on clear-eyed study and love of nature, rather than on the invention and the 'personality' of the artist of which we hear so much. The work of the true artist is marked by fidelity to nature, and proof of this may be seen in any great art gallery. But people write much about art in magazines and papers who are blind to its simple law, and we may read essay after essay about it without being brought a whit nearer to the simple truth. On the other hand we get a false idea that it is not by observing, but by inventing and supplementing, that good work is done. The strong man must be there, but his work is to see the whole beauty of the subject, and to help us to see it. To distort it in any way for 
the sake of making it 'original' is often a way to popularity, but in the end it means bad.work. It may be the fashion for a season, owing to some one quality, but it is soon found out; and we have again to turn to the great masters of all ages, who are always distinguished for truth to nature, and show their strength by getting nearer to it.

Realism and idealism. Beauty in its fulness and subtlety, which is the justification of 'art', writers of the day will not take the trouble to see; they write essays on art in which many long words occur, but in which we do not once meet with the word truth. 'Realism' and 'idealism' are words freely misused, and bad pictures are shown us as examples of 'realism', which leave out all the refinement, subtlety, truth of tone, and perhaps even the very light and shade in which all the real things we see are set. There are men so blind to the beauty of actual things that they seek to idealize the eyes of a beautiful child or the clouds of heaven; yet we know that no imagining can come near to the beauty of some things as they are, art itself being often powerless to seize their full beauty. Only a little, indeed, of the beauty that concerns us most-that of the landscape-can be seized for us except by the very greatest masters. Of things visible-flower, tree, landscape, sky, or sea-to see the full and ever-varied beauty is to be saved for ever from any will-o'-the-wisp of the imaginary. But many people do not judge pictures by nature, but by pictures, and therefore miss the subtleties and delicate realities on which all true art depends. Some sneer at those who 'copy nature', but the answer to such critics is in the work of the great men, be they Greeks, Dutchmen, Italians, French, or English. 
Choice essential. It is part of the work of the artist to select beautiful or memorable things, not the first that come in his way. The Venus of Milo is from a noble type of woman-not a mean Greek. The horses of the Parthenon show the best of Eastern breed, full of life and beauty. Great landscape painters like Crome, Corot, and Turner seek not things only because natural, but also because beautiful; selecting views and waiting for the light that suits the chosen subject best, they give us pictures, working always from faithful study of nature and from stores of knowledge gathered from her; that also is the only true path for the gardener, all true art being based on her eternal laws. All deviation from the truth of nature, whether it be at the hands of Greek, Italian, or other artist, though it may pass for a time, is in the end-it may be ages after the artist is dead-classed as debased art.

Why say so much here about art? Because when we see the meaning of true 'art' we cannot endure what is ugly and false in it, and we cannot have the foregrounds of beautiful English scenery daubed with flower-gardens like coloured advertisements. Many see the right way from their own sense being true, but others may wish for proof of what is urged here, as to the true source of lasting work in art, in the work of the great artists of all time; and we may be as true artists in the garden and home landscape as anywhere else.

Artists in planting. There is no good picture which does not give us the beauty of natural things, and why not begin with these and be artists in their growth and grouping? For one reason, among others, that we have the living things around us, and not merely representations of them, as in the other arts. 
So far we have spoken of the work of the true artist, which is always marked by respect for nature and by keen study of it; but apart from this we have a great many men who do what is called 'decorative' work, useful, but still not art in the sense of delight in, and study of, things as they are-the whole class of decorators, who make our carpets, tiles, curtains, and who adapt conventional or geometric forms mostly to flat surfaces. Skill in this way may be considerable without any attention whatever being paid to the art that is concerned with life in its fulness.

This it is well to see clearly, as for the flower gardener it matters much on which side he stands. Our gardeners for ages have suffered at the hands of the decorative artist, when applying his 'designs' to the garden, and designs which may be quite right on a flat surface like a carpet or panel have been applied a thousand times to the surface of the reluctant earth. It is this adapting of absurd 'knots' and patterns from old books to any surface where a flower garden has to be made that leads to bad and frivolous design-wrong in plan and hopeless for the life of plants. It is so easy for any one asked for a plan to furnish one of this sort without the slightest knowledge of the life of a garden.

Degradation of flowers. And so for ages the flower garden was marred by absurdities of this kind as regards plan, though the flowers were in simple and natural ways. But in our own time the same 'decorative' idea has come to be carried out in the planting of the flowers under the name of 'bedding out', ' carpet bedding,' or 'mosaic culture', in which the beautiful forms of flowers are degraded to the level of crude colour 
to make a design, without reference to the natural form or beauty of the plants, clipping being freely done to get the carpets or patterns 'true'. When these tracery gardens were made by people without any knowledge of the plants of a garden, they were found difficult: to plant, hence there were attempts to do without the gardener, and get colour by the use of broken brick, white sand, and painted stone. All such work is wrong and degrading to the art of gardening, and in its extreme expressions is ridiculous.

The term 'artistic'. As I use the word 'artistic' in a book on the flower garden, it may be well to say that it. is used to mean right and true in relation to all the conditions of the case, and the necessary limitations of all human arts. A lovely Greek coin, a bit of canvas painted. by Corot with the morning light on it, a block of stone hewn into the shape of a dying gladiator, the white: mountain rocks built into a Parthenon-these are all. examples of human art, every one of which can only be fairly judged with due regard to what is possible in the material of each-knowledge which it is essential the artist should possess. Often a garden may be wrong in various ways-as conifers spread in front of many a house; ugly in form, or not in harmony with our native or best garden vegetation, as shown in mountain trees set out on dry plains and not even hardy; so that the word inartistic may help us to describe many such errors. Again, if we are happy enough to find a garden so true and right in its results as to form a picture that an artist would be charmed to study, we may call it an artistic garden, as a short way of saying that it is about as good as it may be, taking everything into account. 
Landscape painting and gardens. There are few pictures of gardens, because the garden beautiful is rare. Gardens around country houses, instead of forming, as they might, graceful foregrounds to a good landscape, disfigure it all, and drive the artist away in despair. Yet there may be real pictures in gardens; it is not a question of patterns, but one of light and shade, beauty of form, and colour. In times when gardens were made by men who did not know one tree from another, the matter was settled by the shears-it was a question of green walls only. Now we are beginning to see that there is a wholly different and higher order of beauty to be sought for in gardens, and we are at the beginning of a period when we may hope to get much more pleasure and instruction out of this art than ever before.

Artists of real power would paint gardens and home landscapes if there were real pictures to draw; but generally they are so rare that the work does not come into the artist's view at all. Through all the rage of the 'bedding-out' fever, it was impossible for an artist to paint gardens like those which disfigured the land from Blair Athol to the Crystal Palace. It is difficult to imagine Corot sitting down to paint the Grande Trianon, or the terrace patterns at Versailles, though a poor hamlet in the north of France, with a few willows near, gave him a lovely picture. Once, when trying to persuade Mr. Mark Fisher, the landscape painter, to come into a district remarkable for its natural beauty, he replied: 'There are too many gentlemen's places there to suit my work,' referring to the hardness and ugliness of the effects around most country seats, owing to the ironbound pudding-clumps of trees, railings, capricious clip- 
pings and shearings, bad colours, and absence of fine and true form, with perhaps an ugly house in the midst of all. We ought to be able to do better than scare away the very men who would enjoy our work most, and delight in painting it, rich as we are in the sources of beauty of tree or flower. 


\section{CHAPTER III}

HOME WOODS

At the beautiful gate of the woods one happiness awaits us, in being free from vain considerations about 'styles'. Our home wood should be only a nobler kind of garden, and may be so treated without spoiling its value as a wood. We may see on a spring day in one place more beauty in a wood than in any garden, from the bushes and plants wild in the place: Furze, Crab, Cowslip, Wood Hyacinth, Primrose on northern slopes, Marsh Marigold in wet copses, and Sloe. But this great beauty often has to be sought through briery paths and dense underwood, and the best of it is not easily brought into relation to the home grounds. In many country places, where people labour for years with a wretched stereotyped kind of garden, they take no trouble to see the beauty of the wild things that grow near naturally and without cost or care. The supreme beauty of our native trees is often a sealed book to them, while they perhaps spend time and money on trees that are tender, ugly, and useless in our land either for wood or garden.

The wood is a mighty worker for man, a precious gift of beauty as well as profit. For the wood, unlike the farm, wants few costly labourers, no weeding or ploughing, finds its own fertilizers, its own watering, its own shade and shelter, all this and much more, and without the aid of the colleges now thought necessary to make the good gardener or farmer. If all the wit of man, 
backed by all the learning of the colleges, were on one side and a wood of our best native trees on the other, the wood would certainly give a better return than could be got from any labour or capital applied to the same class of land in other ways.

Evergreen woods for beauty. Even in the most frequented lines of country we often see the ugliness which results from neglecting to plant those most precious gifts of the hills, the Mountain Pines. With few exceptions the best of these are the trees of northern Europe and America, massed in serried armies on the mountains, and grown on the hilly ground to a vast extent in central Europe. The first good reason for planting evergreen woods is their beauty. This we do not get in the kind of pleasure-ground planting of which the object is to grow each tree as a specimen dressed down to the ground in a green 'crinoline'. It is only by grouping and massing hardy evergreen trees that we can see their highest beauty, which in most kinds is in the mast-like stem. Nothing in the form of trees may so much influence the look of country as these evergreen trees.

Shelter. In continental countries, where the winds are powerful enough to destroy the crops, shelter belts of evergreen trees are a great defence; much more so in our wind-shorn coast land we have reason to seek shelter. If, owing to the vast length of exposed coast, we neglect to give shelter, the trees and shrubs are cut off as by giant shears above the walls. But where we have the evergreen wood (beginning with wind-resisting shrubs, working up to the higher trees) we have shelter, as at Bodorgan in Anglesey, on one of our most windshorn coasts.

Planting poor land. In dealing with poor land the 
question of profit cannot be excluded, and to what better use could one put bad land, poor rocky slopes, starved sandy flats, boggy hills (as in Ireland) in wet districts, and land too cold and poor to be ploughed with any profit? There is no way we can use much of such land so well as by planting it with the true evergreen forest trees. There is no Saturday night in the woodland; it puts on its profit without other care, adorning and sheltering the land, helping the living creatures that haunt the woods, and adding in many ways to the charms of the country. Few know the power of evergreen trees to grow on the poorest land. We cannot grow Oaks on nothing, but I have seen young Pines sow themselves on land from which the top soil had been entirely removed by gold hunters. Many poor, cold, ill-starred hill-sides of the north of England, Wales, and Ireland could grow the Mountain Pines as well as they grow in their native lands. The Corsican Pine makes a growth of from 20 inches to 3 feet a year in a quarry I know from which every bit of soil has been removed.

Quickness of growth. Another reason for choosing evergreen trees for planting poor land is that woods can be so quickly raised. If we make a right choice of young plants and wire against rabbits and hares before planting, we may raise sheltering woods in ten years. Little plants, after a few years' struggle with the turf, are soon tall enough to give us the shelter and effects which only evergreen woods can give. Our climate helps us if we only know how to take advantage of it, because of its affinity to the sub-alpine conditions in which the great Pines of the world so often grow in lands below the snow-line. All the Pines of Europe are easily grown as forest trees in our country, because the 
conditions are something like those of their natural climate. If we go to the North African mountains we find the Cedars growing where the snow lies until May, our wild flowers and our Thorn and Yew growing with them. The Atlas and Lebanon Cedars, loveliest trees of the northern world, are as hardy as the Pines of Europe if we only plant them rightly. In the same conditions also the Numidian Fir is happy, and quite hardy in our climate.

Fuel. In the country house, all the cooking and heating might be much better done with wood fuel; the British kitchen range is a costly deception, and, if all our coal-mines failed, every country parish might grow its own fuel and light. Yet it is a common thing to see people bringing coals from Newcastle, and carting it miles from a railway station, whilst abundance of fuel lies rotting in their woodlands. The wealth of Britain in coal has been our loss, in leading us to forget the old ways of cooking and warming. The architect and the housemaid, and the modern grate and chimney, are all against us, and it is not uncommon in a country house to see people shivering round an ugly grate with a coal fire. Our evergreen wood is not such good fuel for the open fire as the native hard woods-Oak, Beech, Ash, or Maple-but for closed ranges and furnaces it makes a good fuel. I have lately been staying in a country house in Hungary, where all the cooking was done with wood, there being thirty-five people to provide for. Even the electricity for lighting the house and offices was generated from the grubbed stubs of Fir trees, which in this country would be left to rot. Every cottage on the estate was warmed with wood only, and with perfect comfort. The objection to the greasy coal of northern England, 
apart from its cost, is that it pollutes the air of the country as well as that of the town, and many good gardens and country houses are defiled by it. I have placed in cottages a wood-burning kitchener which answers well, and people are grateful for the cleanliness and the good cookery and baking done with it. The fuel we use is such as may often be had in old shrubberies and underwoods-batwood it is called-of slight value in the district. Some simple means of cutting it up is all that is needed for economy.

As some of the Pines grow three feet a year in soil too poor for any agricultural use, few words are needed to give an idea of the enormous amount of firing that might be grown in this way, even from the mere thinning of the woods. And here it should be said that we must in all cases follow the true forest way of close planting, only thinning when the thinning will pay for the labour, and when the trees to remain are close enough to keep the shade canopy overhead.

Where to plant. The next thing to consider in our evergreen wood is where to plant, and this will differ a good deal according to the ground and district. For the country house it is often desirable to have a sheltered retreat and shade in all weathers, and nothing will give this so well as the evergreen wood, free from labours of all kinds after planting, unlike most underwoods, which are the scene of much labour and delay. A house on high ground, with open land to the north or the east, offers one of the most tempting situations to plant a hardy Pine wood in, not merely for the sake of effect, but also for shelter from the north and east. I have planted such a wood, and raised it in ten years to dignity and beauty. A true Pinetum. A simple Pine wood with rides cut 
through is far better for effect, shelter, and the growth of trees than the labelled and sticky 'Pinetum', which gives neither timber, shelter, nor beauty. In many districts we see iron-bound clumps dotted over beautiful ground, and worse than useless for effect; also skinny belts not deep enough to keep out the wind. As the common ways of planting are so hopeless, what others have we? Well, this is a question of district, of whether the land is valuable or not, and whether it is rich plain or rough upland. Large areas of land were broken up in all parts of Britain when prices were good, which ought never to have been broken up at all, and are not fit for anything but timber. Think of ploughing with four horses in clay land and expecting to get anything back! The same field which breaks a man growing corn at the present prices would give a steady profit if well planted. It is well, therefore, to plant cold and poor fields, no matter what their shape, and from the first year that we plant them we shall have some useful covert. It is not only fields poor from coldness of soil on the clay that are not worth cultivating, because some light lands would be much better planted.

Very often, in diversified country where the land is not valuable, the old way of very small fields for the stock has become almost useless for the present needs of farming. If there are rabbits about, anything grown in the field is eaten up, trees begin to spread in, and there is often hardly room to swing a plough. Then it is often a good plan to plant the whole of the field, suiting the tree to the soil and taking care to bring in now and then a change of tree. For example, in the woodlands south of London we often see hundreds of acres without an evergreen tree anywhere. This cannot be 
good from the points of view of shelter, game, or beauty, and, therefore, it is often well to plant some of these small fields with hardy evergreen trees. Never plant such with Californian trees, which are not everywhere successful, but keep to the evergreen trees of EuropeScotch, Silver Fir, Spruce, Corsican, Austrian, White Pine of Canada, and the Cedar of Lebanon, which people use as a pleasure-ground tree only, although it is as easily raised from seed, and as free and vigorous, as any Pine.

Tail ends of fields running into woods, which often necessitate much fencing within a very small area, are also good places to plant, especially with an evergreen tree which we wish to encourage, as such corners and tail ends are often sheltered by the woods about them. By planting these, and making a simpler line of fence round the field, we improve both the field and the wood, and also lessen the fencing, which is always worth doing.

Apart from taking advantage of the incidents and nature of the ground, there may be a reason to plant for covert in certain positions, and then we must take what ground we can, always keeping to the principle of massing and grouping rather than the narrow straggling clumps which are so common and, generally, fenced with ugly iron. The larger the mass we plant the easier the fencing becomes and the simpler for everybody, both in making and keeping. For cold and wind-swept districts it is often good to plant on the north and east sides of favourite fields or gardens, and it is pleasant to see how much one can do in the way of shelters with evergreen trees, even in ten years, if we exclude rabbits and choose the right kind of tree. The common idea 
that good planting means big planting is a great hindrance to getting artistic results or even good timber, and it is well to learn to enjoy the beauty of little trees and woods, which we may raise in a few years from very small plants. In many cases trees not a foot high will beat those bought in nurseries a yard high. My Corsican Pines came in a basket, in little bundles not bigger than bunches of groundsel, and in ten years they formed a handsome sheltering wood. Certainly the Pine babies make a far from dignified appearance the first year; but I am content to plant small, knowing how well they will grow in a very few years, and how much better an effect I shall get than by planting tall plants. Now, to plant in this way and get a good result for all the future life of the grove, we have not only to know the greater trees of the northern world as distinct in kind, in beauty of form or leaf and in height, but also in relation to time; and hence arises one of the questions concerning good planting for the future, for which all good planting should be.

We have much evidence how quickly woods may be formed by planting in well-considered masses and by the association of things of like nature, as Firs and Pines; and how a man even beginning after middle age may in his own lifetime hope to see noble woods of his own planting. If anything in the world would be enviable by a tree lover it would be the lot of one still young, with much poor land to plant, as he certainly could in his own lifetime raise stately forests. Such good and rapid results, however, can only be got by the absolute exclusion of hares and rabbits and the still worse attacks of young horses or grazing creatures of any sort.

Use little plants. The stock of the ordinary nursery, 


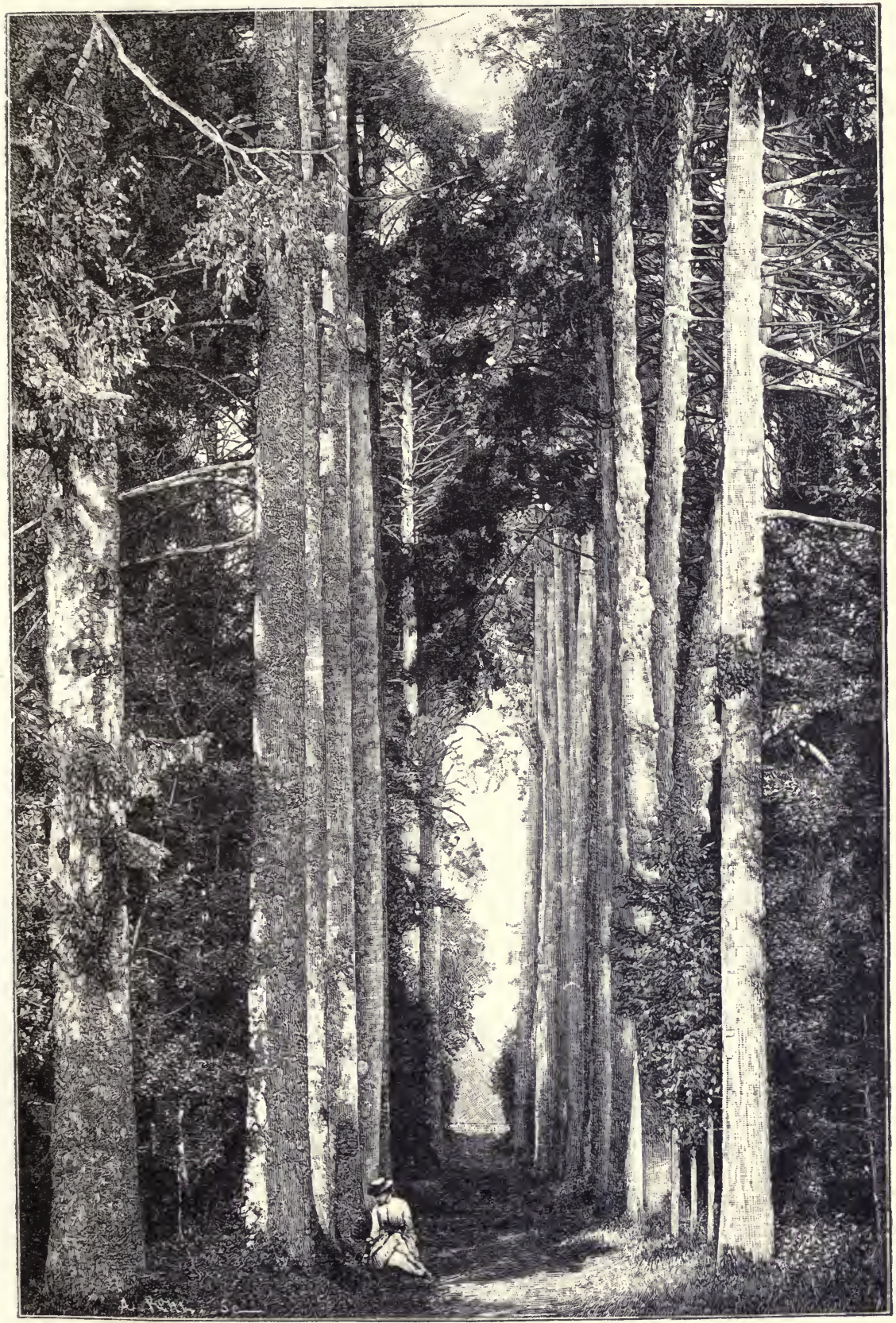

Spruce Wood, Gloucestershire 
等 
being in most cases grown for planting gardens and pleasure grounds, should not be used in woodland planting. For that we must go to the forest nursery, which will give us young and healthy seedlings, the best for all purposes of planting. One or two instances of this may convince the planter of the gain of getting very young trees. In planting a field of Larch, some of the plants received were so very small that the men put them thickly in lines at one side of the field (in stock as it were) to allow them to get bigger. Left there and forgotten, they grew much better than the regularly set-out plants. In another case of planting a field of Corsican and Scotch Pines, mainly small plants, some parts of the field were planted with larger ones, about a yard high, which happened to be in the place, where they stood too close. While the little trees never failed, about two-thirds of those of the larger size perished the first season. Thus will be seen at once the advantage of always getting very young trees in all planting of woodland.

Time of planting. Where we plant good trees in a liberal way, for which there is so often room to spare in poor ground, a plan seldom followed, but a very good one, is that of dating the wood on a stone block, as in the Oak wood at Althorp; or on stout iron posts, as in the woods near Virginia Water. It is very interesting when examining a well-grown wood to know its age, which may also be duly recorded in an estate book of planting - a useful book to have on every estate where the woods are of any extent.

A source of failure. A common source of failure with the nobler evergreen trees is the mixed-muddle way which is common everywhere with us, and fatal as regards the evergreen wood. Planters think merely of the 
effect of the pudding-like masses they form at first, and follow no principle, the planting being too often a mixture of evergreen shrubs of the south of Europe, forest trees of the north, and conifers of California, or any other country, in one mass, usually uniform back and front, and planted for size only. In nature trees have distinct habits of growth, and some notice should be taken of this in planting for the sake of effect or for timber. We rarely or never see a mixture of conifers, evergreens, and summer-leafing trees growing naturally in one place; the Oak and the Pine run together sometimes and, as we go up high mountains, the Beech and the Birch, but the association ceases eventually, and we have the Pine on the higher hills, as we have the Oak on the plain and the Willow in the marsh. Nothing like the incoherent mixture which we see in Britain is ever seen in nature, nor should be seen in any good planting. These remarks as regards stupid mixed plantings are not addressed to the true forester, but to the many people who, often with good opportunities of planting, never think of the matter from that point of view; so that we see under their forest evergreens the remains of flowering shrubs and rare evergreens which are quite unfit for such association, but which grouped by themselves in right positions would have given a beautiful result. I do not say that some association with summer-leafing trees is not right in the Pine wood; in fact, such trees often come by themselves. Oak, Beech, and Ash in a forest country are blown in, or in some way come uninvited and often with good effect. Birch and Beech might even be planted among Pines; but that way has nothing in common with the mixing, which is so wrong, of hardwooded trees with Californian conifers and every con- 
ceivable tree that happens to fit in at first, to make a show of size. And this is but one of the many important things we have to think of, if our planting is to be true and beautiful and lasting.

The beauty of the Pine-stem. A mistake running through the whole of our planting, doing infinite harm from an artistic and even a cultural point of view, and as difficult to eradicate as Twitch or Bishopsweed, is the common one of planting every precious tree we have as an isolated specimen on the grass. I have seen a Monterey Pine, a tree about seventy years old and in fine health, but instead of the stem, such as a Pine should show, its huge branches were massed close to the ground and one could scarcely get under it, thus offering an immense target for rain, or wind, or wind-carried sleet. It grew in grass as usual, and that it throve in the climate of the district was clear from its healthy foliage; but the timber was very much less than it would have been if the tree had been planted rightly, for, instead of being (as in a forest Pine) massed in the stem, it was wasted in twenty great arms. In this way of planting, trees like the Scotch Fir, the Cedar of Lebanon, and the Monterey Pine grow too much to branches, not losing their lower limbs but pushing them out until they become the enemies of the main stem, whence it is we have so many trees thrown down by storms, as well as other evil results from the practice.

Other Pines, like the Columbian Fir (Abies nobilis), never assume this bushy habit but go up like arrows, their lower branches getting weaker as the tree grows higher; massed together, as in nature, the trees lose their lower branches quicker. When the bare stem is seen, many who have not seen the trees in their native 
home attribute it to loss of health, whereas they are merely throwing off tired branches for which they have no further need. In nearly all forest trees, and Pines more than any, it is a distinct gain in beauty to show the stem. The trees escape the wind, and do not suffer from exposure or from being set on grass, which during summer or light rainfall takes all the moisture. They shelter each other, and the mast-like stems are sufficient to uphold them in any storm. What is the remedy for the mistake so often made in planting Pines? Certainly grouping the trees closer together, and so gaining those stately columns, good effect, and timber. If there is not room enough to group each kind separately, that is no reason why different Pines should not be grouped together.

False distinctions. Much of the time and energy of writers is wasted in the attempt to draw distinctions where none exist, ranging from the abysmal profundities of Kant to the last issue of some publication dealing with the simple facts of country life. Attempts are made to set up distinctions in kind where it is only a question of degree. We have the table hen and the exhibition hen, which proved so distressing a bird to Sir Henry Thompson; we have men endeavouring to separate garden from exhibition Roses; critics who write of all sorts of 'schools' in art instead of showing the harmony with nature of all true work in art; and now books of woodcraft show the same tendency and, instead of being simple and clear, use a jargon of German and bad English as pedantic as possible. The tree growing by itself is discussed on 'arboricultural principles'; trees growing in a wood are discussed under another set of principles called 'sylvicultural '. This and much like talk is very apt 
to confuse. Some of the noblest trees for beauty as well as size are in the forests, and I would much rather have Oaks from the forest of Marly or Bercy in the pleasure garden than any merely bushy tree usually grown therein. The greater Pines of the Northern Forest should be grown as they are found in natural forests generally, that is to say, close enough together to get the true form and stature of the central stem.

Firs close planted. I have lately measured some Spruce Fir in a German forest-stems of 70 to 80 feet high, and not more than 3 to 4 feet apart. In some cases they even stood closer. Every tree must have room to grow if it is to attain a useful size, but our way of planting conifers, in which each tree must stand apart, is silly. In the mountains of Auvergne, I have seen fine trees of the Silver Fir within a yard of each other. Doubtless climate, tree, and soil suited each the other, as they always should do if we seek good results from woodland planting; but these instances tell us that the true way is in massing trees of this nature. 


\section{CHAPTER IV}

THE GREATER EVERGREEN TREES OF THE NORTHERN FOREST

I HAVE shown reasons for the planting of evergreen woods: for shelter, profit, use of poor lands, rapid growth, varied uses, and for their beauty in the landscape. The man who does not love the woodland and the tree will never make a beautiful country place; for the questions which cluster round the house itself are as nothing compared with what we have to face if we wish to get the best the ground may give us. We have now to think of the chief question in planting, the choice of stately and first-rate trees; kings of the northern evergreen forest they should be. From many points of view, the planting of evergreen woods is an important one, and, from the number of merely new trees in lists, the question is not always simple. We have a few hardy evergreen trees which everybody plants, but so many trees have been introduced, possessing good qualities in their own country, that people are apt to plant things which can never become in Britain timber trees of any value, however well they may look in nursery rows, or isolated in the pleasure ground with perhaps a dozen loads of good loam under each tree. The mountains of Europe give us the best trees for our islands, needing no special soil or care, and with them thrive the trees of northern Asia, and even southern Europe and Asia Minor, with its noble Cedars of Lebanon. There is 
always a gain in having a tree from a like climate. If we go to California and warm regions for our evergreens we may make mistakes, and costly ones. There are certainly fine trees in the North Pacific region; but for the evergreen woodland we ought to take first the hardiest trees of regions like our own.

We have to steer clear of many pitfalls made for us by catalogues in giving pompous Latin names to mere 'states' or slight varieties of each tree; of fine trees not hardy save in favoured spots, as the Indian Deodar; of false names like Retinospora; of failures like Cryptomeria; of trees starting too early in our spring; of weedy, poor trees like the western Arbor-vitae, and to whole lists of poor varieties of such trees, rubbish for woodland, and little better for the pleasure ground.

Useless evergreen trees. Much has been spent and wasted in planting these, owing to the excitement over the Wellingtonia and other Pacific coast trees. For these, people almost ceased to plant the best native trees and the really good Pines for our land, the main result in many cases, except in the most favoured places, being ugly sticks often half dead. The effect, also, is so ugly in what is called the 'Pinetum' that people might well be tired of planting conifers. But the true 'Pinetum' is the Pine wood, where no tree should ever enter which is not as hardy as the Scotch Fir or the Yew.

The Deodar Cedar is unfit for the woodlands of our country, being tender. The Redwood of California, which is a fine tree in its own country and grows pretty well with us, is injured almost every year even in southern parts of England, though it may thrive as a close wood. Araucarias should never be planted in 
any woodland work, nor should any merely curious conifer, and many absurdities are described in catalogues serving to obscure the value of the really noble Pines.

Design. It is important to get out of our heads skimpy ideas of planting, wrong in effect for shelter, timber, and simplicity of working. North or south, east or west, we often see that, if any planting of evergreen trees is done at all, it is done in narrow skirtings to roads, so that the winds cut through the line in an instant, whereas when trees are massed rightly the edge of the wood impedes the prevailing wind, and within fifty yards the trees are in shelter and warmth. The best way to plant is to take a piece of ground which is not valuable for arable or any other use, and plant it as wood. If, as often occurs, there are few or no evergreen trees among the hardwood trees of the place, it is all the better if we can place an evergreen wood in the midst of Oak and like woods; birds can get more protection in such woods, as in estates with hard woods only it is too easy for the poacher to see the pheasants clear against the sky on the leafless trees. All planting of these trees should be in masses, bold groups or 'clouds' on the hills. It is not a question of space; an acre or two rightly planted would be better than miles of the mean skirtings to roads called 'plantations', and the ugly round clumps with which so many country places are disfigured.

The following are the greater trees for the evergreen wood for our islands. It should be understood that the trees are considered wholly from the point of view of the planter in Britain.

The Corsican Pine. The tallest Pine of Europe, reaching 160 feet high in Calabria and Corsica, and of very 


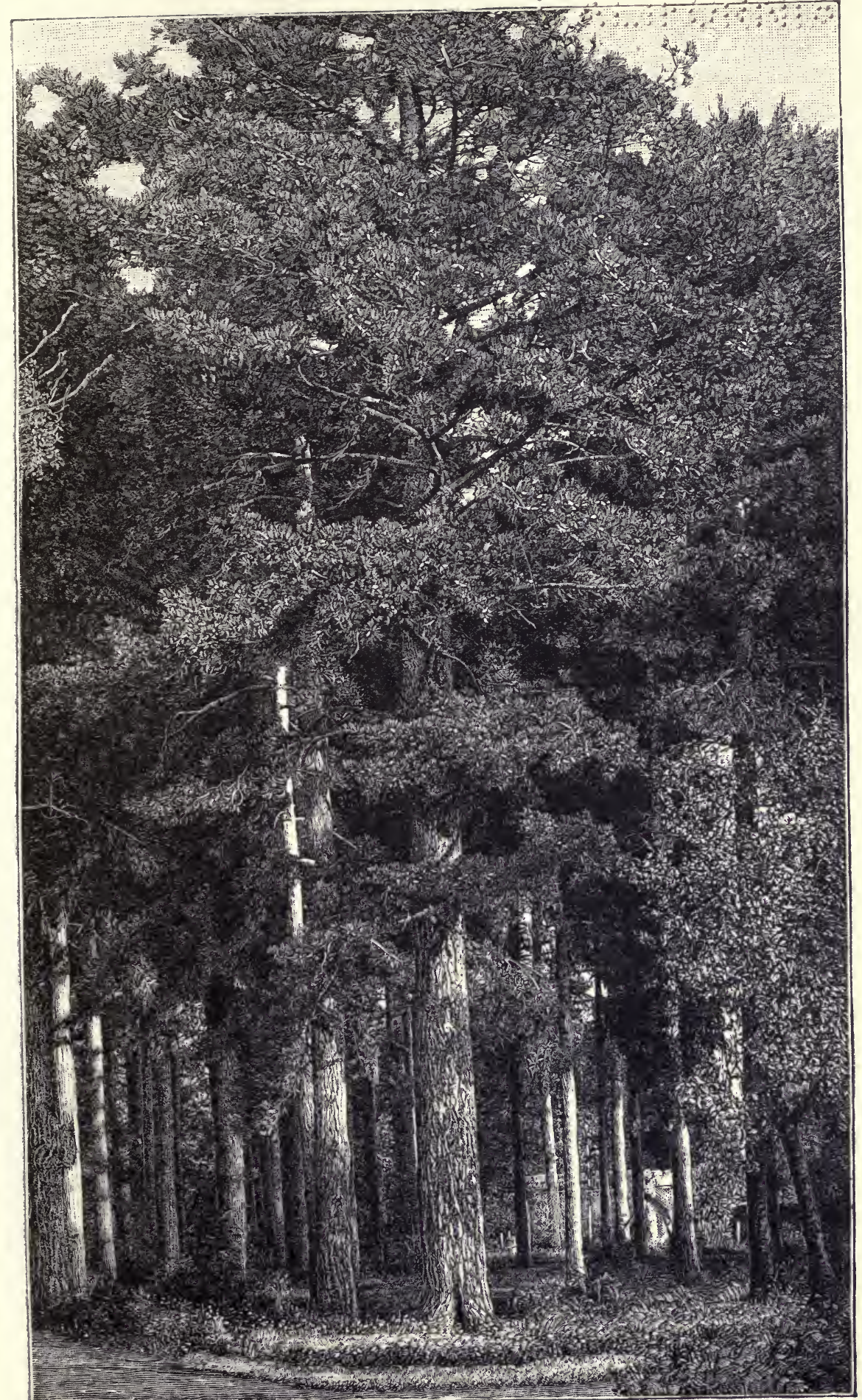


$\therefore-3400000$ 
rapid growth in our country, as I have raised woods of it in ten years. The tree shows some variety of habit and even foliage, and, if one liked to do anything so foolish, one could give Latin names to several forms found in one wood. The Calabrian variety has been named as a species by some, and it is a more vigorous tree in poor soils. Plant small; two or three-year-old plants do best.

The White Pine (Pinus strobus). One of the noblest forest trees of the northern world, reaching a height of over I 70 feet, with a girth of trunk of 30 feet. Owing to the cutting of the woods in its native land, it is seldom seen in its fine form in the settled parts. It forms dense forests in Newfoundland and Canada, and westwards and southwards along the mountains. In our country it thrives best in gritty and free soils. I find it perishes when growing on some clays, and this is not owing to any want of hardiness, as it is as hardy as any northern tree.

The Cluster Pine ( $P$. pinaster). A rapid-growing Pine of pleasant colour, 70 feet or more high, native of the Mediterranean region, often by the seashore, and useful in our country near the sea, but often thriving in inland places, best in free and sandy soils. It is used much in France to aid in fixing sand dunes.

The Scotch Pine. Our native Pine, and, when old, one of the most beautiful. It is of very wide distribution in northern, Arctic, and mountain regions, and also on the mountains of Italy and Greece. The Riga variety is a more erect and stronger grower. A number of varieties are mentioned in books and catalogues, and some hybrids, compact and dwarf varieties, including variegated ones, none of any value for the woodland. This Pine 
sows itself in some heaths, and is rapidly spreading in that way in some districts.

The Monterey Pine (P.insignis). A grass-green Pine of California, often thriving in the southern and western parts of our country, but in inland places occasionally suffering in hard winters, and therefore not good for general planting, except on high ground. The tree is so distinct and beautiful that it should not be forgotten in the southern and milder shore lands.

The Swiss Pine (P. Cembra). A noble alpine Pine of distinct, close-growing form, a slow grower in our country, as well as in its native land on the mountains of central Europe or in Siberia, where it attains a maximum height of roo feet. This is a tree of rare beauty and its wood of fine quality; its slow growth at first does not lessen its great value.

The Austrian Pine. One of the hardiest trees; distinct in form and colour, attaining a maximum height of nearly roo feet; of close, dense growth when young, thriving on calcareous, poor, stony or rocky ground and on clay soils (but not on poor sands). Owing to its close habit it nourishes the ground beneath it so well with its fallen leaves that it is self-supporting and gives precious shelter. It is often planted in Britain, but generally set out in the usual 'specimen way', so that it is slower in taking its true form than when grouped as Pines should be. The final form of the tree is very picturesque, with a free open head; giving valuable wood, however massed it should be thinned so as to allow of its full development. In books this Pine is sometimes classed as a variety of the Corsican Pine, but, from a planter's point of view, the trees are distinct in colour and form and growth. 
The Cedars of Lebanon and Atlas. Planters should not forget that it is to the Cedars of the northern mountains they must look-the Lebanon and Atlas Cedars, which have been proved so hardy and so well fitted for our country. In books Cedrus atlantica is considered distinct enough to merit a separate name, but, having seen the trees on their native mountains, I think the Atlas Cedar is only a form of the Lebanon Cedar (C. Libani). The seed of the tree is plentiful in Asia Minor and North Africa, and it ought to be grown in forest nurseries and offered among the other forest trees. The seed being as easy to raise as that of any other conifer, we should not buy the tree in the 'specimen' state, but in the smaller state, a much safer way. These Cedars should be grown as forest trees, and they will take high place in the ranks of such.

The Common Yew (Taxus). Our best native evergreen, though neglected by gardeners as a tree, must not be left out in planting evergreen trees, as it is such a welcome shelter for game, and when old very beautiful with its finely coloured stem and everlasting verdure. In woods, too, we have the best chance of growing it out of harm's way, as no asp of tropic jungle is more deadly, and thousands of precious living creatures have been killed by Yew. Plant as far in the centre of woods as may be. Keep all old trees with reverent care. The lower branches of Yews should be cut off where there is any danger of stock reaching them.

Lawson's Cypress (Cupressus Lawsoniana). A tall and beautiful tree of the Pacific coast of North America, Ioo feet high, and very free in our climate. Unfortunately, owing to propagation from cuttings instead of in the natural way from seed, the tree often breaks into 
a number of stems, which interferes with its natural habit and beauty. It varies very much into what is called 'sports'. There are a number of fastigiate forms, but they are malformations, and only the natural wild form raised from seed should be planted.

The Canoe Cedar ( $C$. nootkatensis). A distinctly beautiful tree, hardy, a native of the northern Pacific coast, and with even more than the grace of the Italian Cypress. It thrives in cold, ordinary soils, and it is a pleasure to see it at all seasons. In its native land there is a copious rainfall, and it thrives in wet districts in our country. Syn. Thuiopsis borealis.

The Great Japanese Cypress ( $C$. obtusa). A beautiful evergreen tree of the mountains of Japan, better known in our gardens under the wrong name of Retinospora. It grows nearly roo feet high, and in its own country it is much used to form avenues. It has many varieties with Latin names, but few of them of real value as they grow old, and these varieties and their Latin names and propagation by cuttings will no doubt do their sorry work in blinding us to the value of the wild tree. Only plants from seed are worth planting.

The Douglas Fir. The most valuable evergreen tree introduced for timber production, and now a common tree. It should be planted in sheltered valleys or woods, but will live in all soils ranging from light sands and gravels to moderately stiff clay. There are several varieties of the tree, that known as the Colorado variety being considered the hardiest but not the best grower. Its growth in Ireland and Scotland is very fine.

The Sitka Spruce (Abies sitchensis). In places where this Spruce thrives it is a beautiful tree with bluish silvery-grey leaves. In a damp climate, where the soil 
is deep and moist, it grows into a noble tree, but in dry soils it is poor. It comes from a very cold part of the northern world, and is a precious tree for Britain, and among the best evergreen forest trees.

The Rocky Mountain Spruce (Picea pungens). A valuable tree for this country, as it is very hardy, quick in growth, and withstands exposure in high-lying places. It is most generally known in gardens by its variety glauca, which is perhaps the most silvery of Spruces, the whole tree being like a cone of frosted silver. This Spruce is largely raised from seed in order to select from the seedlings these silvery varieties, and it is the normal form which is of less value for gardens that is so useful for exposed plantations. I find this tree very good in poor stony ground.

The Norway Spruce. One of the most planted of trees, and yet often failing in the southern and dry counties, except near water or in wet bottoms. It is a mistake to plant it on high exposed places or in very dry soil, but over a large area of the western country it is valuable, and in Ireland and Scotland. Its failure in the southern counties is owing to their low rainfall.

The Silver Fir. A noble tree of the mountains of central Europe, often planted in Britain, and growing well over roo feet high in many places. It was the first of the Silver Firs planted in Britain, and one of the best. When young it grows well in the shade of other trees, and it is an excellent tree to plant for shelter, as it will grow in the most exposed situations, and in peaty as well as most soils, but it is slow to start growth in some clay soils.

The Giant Arbor-vitae (Thuja gigantea). A tall and noble tree, fine in stature and form, hardy in our country, 
thriving in ordinary soils, and a free and rapid grower, even without the special attention in the way of soils such conifers often receive. Avoid cutting or sucker plants. It attains in its own country a maximum height of 150 feet, and its wood is fine-grained and good. N.W. America, finest on the Columbja river. Syn. T. Lobbii.

The Puget Sound Fir (Abies grandis). A stately tree of over 200 feet high, with dark-green cones 2 to 3 inches long, and dark shining leaves, white below. Hardy and free in various parts of Britain; best in moist soils, and promises to be a valuable tree for our islands. N.W. America.

The Columbia Fir (Abies nobilis). A mountain tree 200 to 300 feet high, with silvery foliage, tipped with bright green as the young growths start in spring, and set with handsome brown cones 5 to 7 inches long. It is hardy in this country save in cold low lands towards the north, and when sheltered and well suited as to soil it thrives remarkably. Shelter is of importance, for the tops of vigorous young trees are not infrequently blown away in a gale, if too much exposed. They seed freely in this country, and soon make timber. The finest trees in this country are upwards of 80 feet high, with a girth measure of 8 feet. Oregon.

The Crimean Fir (Abies Nordmanniana). A beautiful tree of too to 150 feet, with rigid branches, dense darkgreen foliage, and large cones. It is hardy and of rapid growth when well placed, the new shoots making and ripening their growth within a few weeks. It will grow in almost any soil, and even in dry sandy places where many Firs refuse to thrive; but in such soil it is particularly liable to a blight like the woolly aphis which finally destroys the trees. This pest follows the tree 


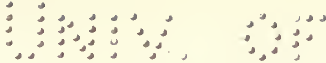

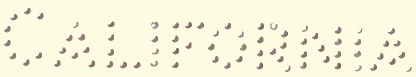

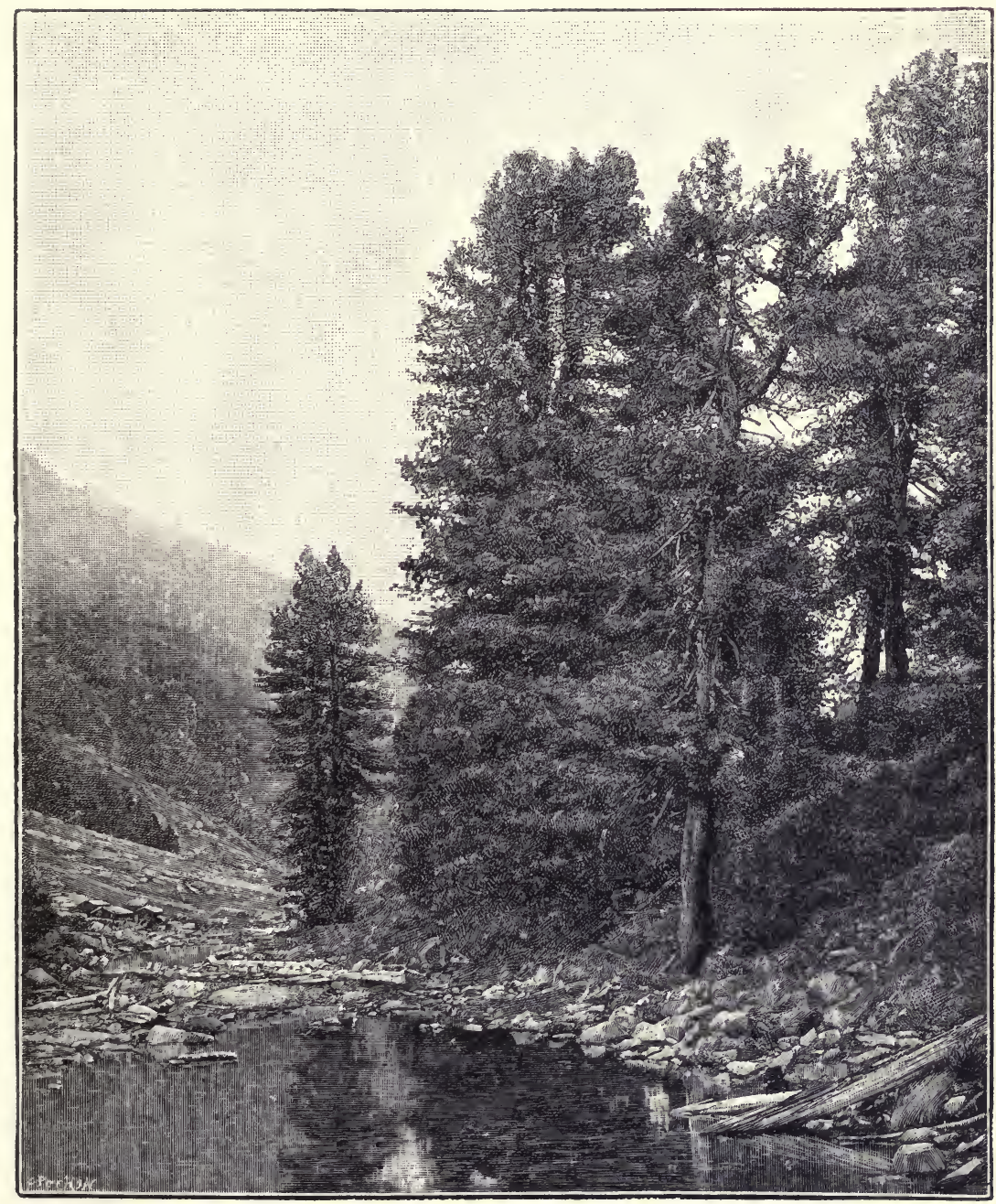

The Swiss Pine (P. Cembra) at home 
so persistently in some places that many planters have abandoned its use. Caucasus and Crimea.

The Red Cedar (Uuniperus virginiana). A graceful, hardy tree on the hills and mountains of N.E. America, giving somewhat of the effect of the Eastern Cypress in Italy, and in our islands a good sheltering tree, thriving in the poorest of soils and rocky places.

The Hemlock Spruce (Tsuga canadensis). A tree sometimes over roo feet high with a diameter of 4 feet in the trunk, inhabiting cold northern regions from Nova Scotia to Minnesota. This tree has been much planted in England, but it has not attained the stature and form that it shows in Canada. But it should not be left out in any varied planting of evergreen forest trees, choosing for it cool soils or river banks.

The Western Hemlock Spruce (T. Mertensiana). A noble tree of graceful habit, a larger tree than the Canadian Hemlock Spruce-sometimes 200 feet high, with a trunk diameter of 1o to 12 feet. A native of Puget Sound, British Columbia to Alaska, and coming from such fog-moistened regions hardy in our island climate. The foliage, as graceful as a Fern, is of a lustrous green, and silvery white beneath. It is a tree precious for our country.

The Yellow Pine (Pinus ponderosa). A noble tree covering a vast area in its own land, where it thrives under a variety of conditions and in many soils. Fully grown trees attain a height of nearly $25^{\circ}$ feet, with stems upwards of 6 feet in diameter. In this country it has not been much planted except as a pleasure-ground object, though it grows well in most parts of Britain, is hardy, and of rapid growth. It thrives in free and gritty soils, and is at home in poor Surrey sands where few of 
our native trees would thrive. Its appearance is very distinct, with a sturdy trunk and few branches, coming in regular whorls, and drooping with age. Tried on poor limestone soil at Grignon in France, it has outstripped the Corsican Pine, and promises to be one of the best timber trees.

Jeffrey's Pine (Pinus Jeffreyi)-better known in this country-is a mountain form of $P$. ponderosa, not quite so rapid in growth, but more resistant to the Pine beetles and certain diseases which attack the Yellow Pine.

The White Fir (Abies concolor). Perhaps the most valuable of the American Firs, it is remarkable for vigorous growth and resistance to heat and drought. It reaches a height of 200 feet and upwards, with a trunk diameter of 6 feet, a narrow pointed crown, and spreading frond-like masses of foliage. Brought to this country about forty years ago, there are trees already upwards of 60 feet high with a girth of 7 to 9 feet. It is a variable tree, with several forms-Abies lasiocarpa with an erect habit and slender stem, and $A$. Lowiana with a stouter trunk and more spreading in its outline. All, however, grow freely on well-drained land, in places not too liable to spring frosts. Along the coast of New England it has been freely planted in seashore gardens, and some of the finest trees are to be found fully exposed to the fierce winds sweeping in from the Atlantic -winds which frequently drench the trees with salt spray without any ill effects. It should be tried under similar conditions on our coasts, and deserves consideration as a forest tree. Syn. Abies Parsonsiana. N.W. America.

Caucasian Spruce (P. orientalis). An elegant tree with 
somewhat the appearance of the Norway Spruce, but it is a smaller-growing tree with much shorter leaves and branches, of denser growth, and is of a deep green, very hardy, and thrives best in moist soils. Massed it forms a fine shelter.

Tiger-tail Spruce ( $P$. polita). A Japanese tree which, judging by the trees in various parts of the country, is one that will have a future in these islands. It is a handsome tree of rigid pyramidal outline, and with leaves the stiffest and sharpest-pointed of all. It stands exposure well, and is a tree for high windy places.

$P$. Morinda. No other Spruce has such gracefully drooping branches as this Himalayan tree, and it is worthy of a place among the finest trees, but it must have a deep, moist soil, more heavy than light, and the position not too sheltered. Under these conditions it flourishes in the bleakest parts of the eastern counties, where are some of the finest trees of it. Syn. $P$. Smithiana.

Bhotan Pine ( $P$. excelsa). A handsome tree, much planted, with long, slender, drooping leaves and pendent cones. It is a native of the Himalayas, and of very wide distribution in Asia. In our country it thrives in warm and well-drained soils.

Cascade Mountains Fir (Abies amabilis). A tall massive tree with deep blue-green foliage and dark purple cones. It grows rather slowly with us, the tallest tree being not much above 40 feet, whereas in the mountains of the western American States it attains a maximum height of 250 feet with a trunk 4 to 6 feet in diameter. It is a noble tree, the branches sweeping down in graceful curves, clothed with dense foliage silvery on the under-sides of the leaves, and during May conspicuous 
for the fine red catkins of the male flowers. It is still a scarce tree in this country, and difficult to get true to name and on its own roots. The wood is light, hard, finely grained, and of a pale brown. British Columbia and southward to Oregon.

The White Spruce (Picea alba). A graceful tree of pyramidal habit in its early state, broadening and rounding off with age, while the slender branchlets are finely pendulous. It grows best in cool and moist places, upon the banks of lakes and streams, decreasing in size and vigour southward where exposed to heat and drought, which it cannot endure. It is abundant in Canada, reaching a height of 150 feet, and is much used in the manufacture of paper-pulp and for fitting interiors. The mature wood is light and hard, finely grained, and readily stained or polished. Syn. P. canadensis.

The Big Tree (Sequoia gigantea). At first I intended to omit this tree from the greater trees of the Northern Forest, because of its failure in many pleasure grounds. Is this not largely our own fault in placing the tree? The best thing to do would be to give it a fair trial as a forest tree in sheltered woodland valleys, or, where there are none of these, to plant in a sheltered wood, and always among trees and cover of some kind which would help to keep the sun out and the ground cool. Coming from one of the finest climates, with a constant sun and gentle Pacific breezes, the least we can do with it is to take care to place it in the best woodland conditions. We should in such ways give it all the chance of growth our climate affords, and get rid of the toy-tray look of our garden lawns which arises from sticking such trees about in them. The fact that over much of the northern and midland country we may not hope for 


\section{of the Northern Forest}

success with it should be another reason for growing the tree where the woodland conditions are favourable.

The idea that these trees should be planted far apart is wrong. They should, like other forest trees, be planted young and close, say 8 feet, with a Larch between every two trees, to be thinned in after life without losing the canopy overhead. That makes the whole of the trees about 4 feet apart. Later on they must be thinned, but never so much as we are told in books on conifers. The mutual shelter the trees get, the shade for the roots, the warmth and the deliverance from old weary branches which garden planters are always grieving over the loss of, but which the tree in nature always gets rid of, help in all ways. I can imagine nothing grander than a grove of Big Trees grown in these forest ways. Eventually the Larch or other nursing tree would have to be cut away and the trees themselves thinned to 20 or more feet apart according to age and size. 


\section{CHAPTER V \\ THE GREATER SUMMER-LEAFING TREES OF THE NORTHERN FOREST}

However much we may rejoice in the Mountain Pine, we are men of the plains and also the broad-leaved trees, Oaks and Beeches and Ash. To these and to their many allies is also given the palm of beauty for their wondrous changes throughout the year and loveliest colour, from the down-clad buds of the early year to the world-splendours of the fall, when the leaves show us how to die. To them also belongs all the most valuable timber: but here we are concerned mostly with beauty.

Why is it that the highest beauty of our native trees is not so evident to us as it ought to be, where there is room to plant? It is because of the 'dotting' planting and the underwood ways in woodland, which prevent the trees from taking their stateliest forms. Then there is the open way of planting, in which every tree stands apart, a way that is dead against good effect and good timber.

If this is the fate of our native trees, to be as often planted without picturesque effect in most country places, how much more so it is true of American and other exotic trees, for many years planted as 'specimens' for the pleasure ground, often being much-transplanted trees, grafted trees, or, worse still, rare trees raised in pots: the result of such plantings being that a tree has not had a fair trial. Look at a transplanted Oak and 
a seedling Oak growing where the seed fell, and what a difference in favour of the seedling tree. It is therefore certain that our woodland interest would be much increased in beauty if, in the case of the finer trees, we were to sow them where they are destined to grow as trees. Grown from seed where they are to grow and in not unsuitable soil, we should see quite a very different and better result.

The Common Oak. King of the Northern Forest, from its use, beauty, and associations, it is in all ways the most precious of our native trees. The beauty of the Oak is evident in many parts of our country, differing, too, according to place, its effect in the south, for instance, not being the same as in the midlands, where the trees are more stately though their wood is no better, if, indeed, as good. In chase, or park, or lawn, nothing can be finer than our picturesque sentinel Oaks; but one noble aspect of the tree, not so often seen with us, is its tall forest dignity. Owing to the trees being so often set apart, and to the underwood culture which encourages them to branch out, we do not so often see those superb erect trees such as may be found in the great French forests like Fontainebleau, Marly, and Bercy, where the Oaks are noble in stature as well as in size, and over roo feet high. Where Oaks are massed in this way the effect of the lichen-silvered stems in winter is fine, and in spring is even better, where the ground is carpeted with Primroses and Ladies' Smocks, Dog Violets, and Wood Hyacinths.

For the Oak the best soils are clays and cool loams, and the iron-soaked soils so common in the Weald of Sussex and in Kent. A deep soil is not necessary if the subsoil is cool. Dry and poor sandy soils are against 
the Common Oak. - Happily there are large areas in which there is the right kind of soil, and many of the poor clays and cold, hungry loams that were broken up in better times might now be well planted with Oak. Nothing that the wit of man could devise pays so well as an Oak wood in many districts of Britain. Oak will grow very well on fine rich loams, but the best quality is grown upon soils which, although cool, cannot rightly be classed as good loam. In my woods, and in the district around, the Oak is as good in quality as has ever been cut, although the ground it grows upon is saturated in winter and, indeed, for a great part of the year.

If we watch what goes on under a grove of Oaks after a good year of acorns and in places not too much exposed to creatures that store them away, we see a fine vigour of growth from seed such as no other tree can surpass. These, be it observed, are uncovered acorns, and, seeing this, who need be afraid to take the simple way with acorns? A plan I have practised with success is to scatter acorns over a field of likely ground and then run the plough through the field to cover up the seed. The acorns will thus be thrown into lines and protected from the birds and other creatures during the winter. They come freely, and, if not severely gnawed by vermin, will be too many, but it is very easy to thin out the weakest. The acorns should be from sound, fair-sized trees-often an easy matter to obtain, though in the same place we have often found a curious diversity in their size. In districts where rabbits abound it is absolutely necessary to wire, to a height of $3^{\frac{1}{2}}$ feet and not more than a couple of acres at a time, as larger areas are difficult to control. If this is not done the little seedling Oaks will be eaten down (the larger Oaks are saved 
by their astringency) and several years may be lost; but even then they keep on and in good time get their heads up. There has been much writing as to the superiority of transplanted trees over those raised from acorns, but this is contrary to all the facts of Nature as seen in every Oak wood, where the trees come so freely from seed. Among the various sound reasons for raising Oak from acorns is its economy and simplicity. An important point is the renewal of existing woods in which underwood has been grown for generations; the Oaks scattered through these are occasionally good, but are often spoiled by their spreading heads. As underwood has now ceased to be profitable and its cutting is often a nuisance near the house, it is better to replant the wood with Oak, in which case we shall have to use tall saplings. I plant saplings of from 8 to $\mathrm{I} 2$ feet high, and when they come from good forest nurseries I find they succeed, but they must have been moved often enough to secure a fibrous root.

It is a common belief that the Oak is a slow-growing tree, and the contorted trees one sees in open places to some extent warrant this opinion; it is an error ; the Oak is a rapid grower. Some ten years ago I planted a small field with Pines-the hardiest and most rapid in growth, some of them, like the Corsican Pine, growing 2 feet and even more a year, in favourable spots; in the soil brought by birds and mice a certain number of acorns came up uninvited, and so far these have kept their heads level with the Pines. Some years ago, too, an interesting calculation was carried out upon my own land on Oaks growing in underwood, recording the growth of ten years. It showed a yearly increase of from 5 to $7 \frac{1}{2}$ per cent. in value. 
Varieties and synonyms. From our point of view it is out of the question to consider here the varieties of our noble Oak. If from some high standpoint we look out over any good Oak district, we may see much diversity as regards time of leaf, colour, and even habit, and for hair-splitting students it would not be difficult from these minor differences to establish 'varieties'. But that is futile for our purpose.

The Durmast Oak. Botanists often class as mere varieties, things that may be distinct from a planter's point of view. They do not always know the living trees, which they see as dried specimens only, and without knowledge of the wood, habit, stature, and other characteristics, which are far more essential for us than any technical description of leaves and stamens. This has been the fate of our Durmast Oak, as the result of failing to keep it apart, and the confused writing relating to our Oaks.

The Durmast Oak is one of the greatest and most stately of European trees. Compared with the Common Oak of our heavy Wealden lands, the stem is more erect, more cylindrical, and while less branching produces a greater proportion of heavy branches, which are freer and less twisted. The foliage is easily known even at a distance by its deeper green colour, more even distribution, and greater density, while the entire tree is often more lofty, and with a more regular outline. The leaves are larger and hang more loosely upon their longer footstalks; they also last a little longer than those of the Common Oak; and saplings (particularly in sheltered places) often keep much of their green foliage until the new leaves come. Even bare the tree may be known by its fuller leaf-buds, its own way of branching, and its 
whiter bark, and in autumn by its stalkless clusters of acorns.

Its area is much the same as that of the Common Oak, but, while more restricted to the north and east, it reaches much further south as the 'White Oak' of the Mediterranean region, and abounds in various forms throughout the south of Europe. The great Oak forests of France are largely composed of Durmast Oaks, especially the famous truffle-forests of the south-east.

But while the Common Oak is a tree of the great plains and valleys, the Durmast Oak clings to the hills, plateaux, and mountain spurs, ascending high enough to be found among the Pines; not that it is hardier than the great Oak of the plains, but because it thrives in a drier atmosphere and poorer soils. As regards temperature there is little difference between the needs of the two, although its more confined northern range presumably makes the Durmast Oak less fitted to resist severe cold.

In the main the wood of the Durmast Oak is less rigid and tough than that of the Common Oak, grown in the plains on fertile soil and as a rule among underwood. On the other hand, the wood of the Durmast Oak is less knotty, is straighter in fibre, and truer in grain. It is preferred for cabinet-work, and being of quicker growth, straighter stem, and better adapted for growing in close order, it is more profitable for the production of timber.

While in general not so long lived as the Oak of the plains, its trunk is less subject to decay and from its later leafing the tender shoots are seldom injured by frost. Foresters also claim that it is less open to the attacks of insect pests. In parts of the north and west, and particularly in the Forest of Dean with its rocky subsoil, it is abundant. But as a fact trees of it are not 
easy to obtain, for whereas firms offer the two kinds in their trade lists, there is hardly a grower that ever keeps them apart or can guarantee a stock in any quantity. The true way would be to gather one's own seed from selected trees of the Durmast Oak, on which the acorns ripen a few weeks later than on the other, and to plant suitable land with Durmast Oak.

There remain the most interesting American Oaks, a few of which in our country have been treated as forest trees; but the Red, the Scarlet, and the Marsh Oaks occasionally are seen as pleasure-ground trees. The best way, if we want to give these Oaks a fair trial, is not to plant tall, young trees, but, if possible, sow the acorns where the trees are to grow; and then, with care about the choice of soils, we should be able to really test the value of each.

The Beech. One of the kings of the Northern Forest for beauty and stature, the Beech has this advantage over the Oak that it grows over a much wider area in all sorts of poor and arid situations, from northern Greece to Denmark adorning and enriching the poorest land-chalky downs, sandy wastes, and rocky hills. This is a great merit in view of the vast area there is of down country, often bare of trees, in southern England, as well as on the poor limestone hills of Ireland and the north country. The economic value of this tree we may see in Bucks and the districts near, where ground covered with Beech gives five times what it would yield as arable. To show what a return Beech will give on such soils we have an instance in the great Beech forest at Lyons-la-Forêt in northern France, under conditions of soil and climate which are much like those of our own country; it proves also how valuable are forests of one 
kind of tree when that is the one best suited to the soil. Thus we have evidence of the great value of the Beech in woodlands of the home counties and in the forests of Normandy. It is commonly believed that no shrub will grow beneath the Beech, but this is happily not true, for the best of all our evergreens, the Holly, often grows well of its own choice in Beech woodlands, giving a pretty effect in them, though its growth may be less vigorous than where more exposed. As, however, little else will grow under Beeches, those who care for the beauty of the wood should add groups of seedling Hollies here and there, for the sake of the pretty evergreen undergrowth that may be seen in some of the Berkshire Beech woods and also in Epping Forest.

A variety of the Beech has leaves of deep-bronze or purple colour: it should be used sparingly, and I only name it here because a certain number come true from seed. Some which I have planted in that way promise to take their place among forest trees, and being seedlings we may look forward to some variety of colour.

Loose, gravelly, and permeable soils suit the Beech best when fed with frequent rains; stiff, moist, and swampy soils are not so good, though we may see it sometimes thriving in such land. The chemical nature of the soil is immaterial, and fine Beech trees are met with upon sand, granite grit, chalk, and light soils; but chalky soils as of the Chiltern Hills and South Downs suit it best.

Stocks of young trees are usually abundant in forest nurseries, and only upon the largest estates, or where the soil is specially suited to the tree, is it worth while to raise it from seed.

The Ash. For its high economic value, beauty of form, 
and splendid endurance in northern regions, this is one of the most precious of trees. Many an old Ash about farm-houses is as fine in its winter form as any tree could be; noble in height, too, when grown in high woods. It is an excellent wood to burn and will cook a breakfast in the open air the morning of its fall.

The Ash grows under very varied conditions, but most commonly on the low plains and in broad river-valleys, or smaller valleys where the soil is cool and in which it attains its greatest size and best value. In no part of England is the Ash so tough and so good in quality as in the Wealden districts of Sussex, Surrey, and Kent. In other counties where it grows more rapidly, the wood is not so good. Cobbett, in his 'Woodlands', notices the storm-resisting qualities of the Ash in his clear way, saying, 'It fears not the winds.... I mean that sort of power which the winds have of checking the growth of trees, and especially those winds near the sea-coasts. On the Hampshire coast the wind that comes from the Atlantic is, of course, a south-west wind. You will see the Oaks, when exposed to this wind, sheared up on the south-west side of them as completely as if shaven with a pair of shears. The head of the tree resembles the top of a broad quickset hedge, which is kept sheared up in a sloping form on one side only ... and at the same time the everlasting flinching of the tree and the continuance of the weight on one side, while it is kept shaven on the other, makes the trunk of the tree lean away from the south-west. Close by the side of an Oak like this you will see an Ash of equal size and height standing as upright as if in the most sheltered valleys, and I have looked with the most scrutinizing eye without ever having been able to dis- 
cover that any of the shoots pointing to the south-west had received the smallest injury.'

In forest nurseries no tree is easier to get in quantity and fit for planting, but in places infested by rabbits it is often difficult to establish, little trees being bitten hard and either destroyed outright or reduced to a leprous state. Sometimes, when planting fields of Pine, I have found, from the seeds of Ash being blown from the neighbouring coppices, I have got more Ash than Pines. If taken up in good time these seedlings come in well for planting. In planting young trees those of one to two years are best, and in pure woods rather close planting is best, allowing for loss through ground game; 4 feet apart is not too close. In this way the trees draw well up and thinning is easy, while the thinnings are useful at all ages; close planting need therefore be in no way against the trees having full room to grow at maturity.

The Larch. The best tree that ever came to us from oversea, for its timber, and among the best trees for beauty, is the Larch. In plantations, often ill-made and quickly cut down, one seldom sees its best dignity ; but if we cross the Alps and get into some natural Larch forest, with the huge patriarchs barkless and prone among the young trees, or see the trees in a picturesque group beside some rapid Tyrolese river, or on the rocks over a mountain torrent; or as at Dunkeld, where some of the first trees planted in our islands still stand; then we get some idea of its stately beauty. A native of the cold and lovely mountains of central Europe, it is suited for all parts of our islands, and for many kinds of soil. The Larch is the great tree of the dry, cold regions of the northern hemisphere, where it is found spreading 
across Europe, Asia, and America. Avoiding the rich soils of the plain and the shelter of the lowlands, the Larch seeks regions that are high and cold, and is happiest upon the wind-swept slopes of the mountainside.

The Larch has a great many diseases, but the one that affects us most is that known as 'Canker', and the work of a fungus which has the power not only of living on the outside but also of making its way into the heart of the tree. The remedy is difficult, not to say impossible, to apply in any thorough way. Not unlikely our mild open winters, which are so different from the arctic winters in which the Larch usually lives, have something to do with it, and also, owing to the great popularity of the tree, the fashion in which it has been planted in masses, very often absurdly close. We have seen it planted 18 inches apart, and so weak that the wind blew the trees over. If the disease occurs in such conditions it spreads rapidly. The remedy is to group the Larch more in open and airy places, and the higher and more exposed the better. If used in our moist valleys it is better to go in for mixed planting instead of massing, although here and there one must mass.

There are various and rare kinds of Larch, but for woodland work it is best to keep to the European and Japanese kinds.

The White Willow. This is not popular with planters, but if one wanted to make a picture of an ugly marsh or bare stream bank where is the tree that would do it so well in a few years? Happily it plants itself over the valleys and by the rivers of nearly all European countries; in the valleys of France and in our country, especially towards the east, it is abundant. Whether 
we plant in woodland, wet or marshy places, or beside pools in parks, or by the side of streams, everywhere it helps us with good effect. The very opposite of the Oak in its elegance, lightness, and colour, where the tree grows well by rivers or lakes, tall trees of it may often be seen 80 feet high and from 12 to 15 feet girth. Where distinct effects are sought from a plantation it is necessary to keep off browsing animals. I was once proud of putting 1,800 Willows beside the sources of the upper Medway, but I did not count with cows, rabbits, and water-rats, and I do not think that more than three of the trees survive.

If any thought of artistic planting, in the best sense of what is right and natural, ever enters the mind of men instead of the muddle mixtures of our day, the White Willow will take a high place, for no 'Olive Silvery Sirmio' has a more beautiful effect on marsh, river bank, or rich bottom land.

The great facility in propagation of the Willow, which every grower takes advantage of, is against the tree and is the cause of some writers describing it as short-lived. Naturally, if we increase the tree from shoots we cannot expect the same endurance and stature that we do from seedling trees. Nature did not make the flower seed vessels for nothing, and as the seed is plentiful we ought always to raise the trees in that way.

Apart from its beauty, there are few trees (a fact which is not generally known or they would be more often planted) that are so valuable for their wood, sound trees being precious for making cricket-bats. Large and wellgrown trees are more valuable than Oak and more difficult to procure. The wood is very tough, easy to work, denting and not splitting when struck, and the 
planks are valuable for linings and for brakes because fire resisting. If we want the best timber we should plant by rivers; and also it is in such situations we get the best effects from it, since the spiral leaves go best with other waterside trees and plants.

Like so many other trees, it is all the better for grouping and massing, and we get a much better effect in that way than by mixing it up in plantations, as is so commonly done. The fact that it does best in certain soils should encourage us to plant it there in masses. Better three acres of it than three trees.

As with so many trees there are varieties, but from the forester's point of view they are no good. Botanists class the Yellow Willow (Salix vitellina) as a variety of the white, but from our point of view the trees are distinct in colour, form, and size, as is at once apparent where the two kinds are seen growing side by side. Hybrids between the White and the Crack Willow come nearer to our tree in dignity and effect, but when we plant the White Willow it is better to have nothing to do with any but the true form, always, where possible, raised from seed; and nurserymen who grow Willows should take note of this need.

The Crack Willow (Salix fragilis). In much woodland country south of London the Crack Willow is not very common and occurs only in an incidental sort of way, so that little or no thought is given to it, even by those who know the value of our native trees. But in Essex and other counties it is often a handsome tree, and a profitable one where its uses are known. Gilpin asserted that the Willow did not harmonize well with British timber trees, and some writers have reiterated this absurd statement. Of all the trees grown in Britain, 
not excepting any exotic tree whatever, the Willows rightly grown and grouped are the most beautiful. Few who care for trees and have ever seen a Willow plantation in its prime, will readily forget its beauty, any more than the owner can forget its profit. This Willow, which will not arrive at its fullest size and quality in undrained land, grows freely on the slopes of exposed hills; indeed, there are few situations in which it will not grow, in which respect it differs from the White Willow, which is more of a marsh and river-side tree.

As regards the Tree Willows, some of their supposed hybrids or varieties, such as the Bedford Willow, are worth growing both for effect and for woodland.

The White (or Dutch) Poplar. For many years in England the fashion for coniferous trees has thrown the planting of summer-leafing trees into the background, and among the trees that have suffered most from this neglect is this noble Poplar. Here and there, in getting down from the hills in Kent or in Wiltshire, and going near an old house or village, we see it, perhaps, rising with a splendid dignity from the hollows and we ask ourselves if any tree of our country is more beautiful or stately. Too often it is solitary, whereas it is seen to best effect in groups. In our country, in hollows and sheltered places, there is no tree that could be used to better effect, even in places too moist or unsuitable for other trees. Rabbits are very destructive of young White Poplars, and in a plantation I have made of it many tall young trees are all gnawed round and snap off at the base; so that when planting the White Poplar in places where rabbits abound it should certainly be wired for six or seven years.

A native of our own country as well as of central and 
western Europe, there can be no doubt about its fitness for our climate, but as it dreads the wind, we should avoid planting it in isolated lines, or as a wind-screen, or on a south-east slope, and choose for it a good place in hollows, at the bottoms of slopes, and within woods where underwood is grown, where it can develop to the full its fine and erect habit.

And this applies also to the greater Poplars of the forest,-the ones we are concerned with here being the Green, Black, Italian, and Canadian Poplars.

The Lombardy Poplar. A variety of the Black Poplar, like all varieties of trees, it is inferior to the wild tree in health and vigour. Many trees of it are diseased, especially where the situation is not well chosen for them. The Lombardy Poplar is a great tree in the Italian valleys like those of Aosta, and there it attains a noble vigour, as it does, also, in our own valleys, for the deep soil beside a river is the best for it. Of late years another handsome upright Poplar has come into cultivation, which looks like a variety of the White Poplar, and is said to be wild in parts of Asia, much the same as the Lombardy Poplar is said to be wild in Asia Minor. In forest work omit both these erect forms of Poplars and also all the Aspens and the nursery forms of alba, and keep to the Black Italian, the Canadian, and the White Poplars.

The Eastern Plane. At first sight this classic tree, of which there are many colossal examples in Eastern countries, might be thought out of place among trees of the Northern Forest; but it thrives even in the London squares, and a tree that resists the winters of London and Paris, and, worse than all, the greasy smoke of Newcastle coals, may well take a place among 
the greater trees. For noble shade, rapid growth, smokeenduring, stately stem, and picturesque form, there is no better tree, and among its many good qualities is freedom from insect pests which worry most trees. It is also easy to increase by seed, layers, or cuttings; the first being the best way, the seed coming freely in other countries, if not in ours. The Eastern Plane is not a lover of mountain land, but thrives in river-carried soils in plain and valley. In Eastern countries it seeks the waterside; in our land that is not so essential, still the best growth is always in warm valleys or alluvial soil. Though so much in our midst, the Eastern Plane was for many years mistaken for the Western or American Plane, which does not thrive in our country.

The Locust tree. From a planting and landscapegardening point of view this tree is precious for its fine fresh verdure in summer and autumn, distinct in that way from any trees, and the form of old Locust trees in groups is very good, and quite distinct from that of other trees.

It is of rapid growth, reaching in good soil a height of 70 to 80 feet, with a girth of 15 feet, though such a size is uncommon, the average height of mature trees being 60 feet. When once established it spreads rapidly by suckers, which thrive even in the shade of other trees. When it can be had of fair size its wood is of value, being very hard and lasting, free from knots, working well, and taking a high polish; for making posts, door and window frames, and similar uses, it is equal to Oak, standing exposure better than most kinds of timber. Growing freely in poor and dry soils and fearless of drought, it is often used to plant on railway banks in Europe, and has even proved its value in fixing 
shifting sandbanks along the Rhone, Danube, and other rivers.

The Chestnut. Among the noblest trees of the Northern Forest for its beauty and dignity even in our cold north, for use as food for various peoples, and for its wood. It is a tree of the sandy and granitic hills of central and southern Europe, the Caucasus, and North Africa, living to a great age and often, even in our own country, reaching great size and beauty, as on the terrace at Shrubland and many other places. It does best in free warm loams or sandy soils, and, like most of the other forest trees, it grows much straighter timber when close together than when isolated as it is so often in our country; its effect is good, however, in either case, and old single trees are often beautiful. Its slighter wood is the best of all for poles, fencing, and trellis-work; even young growths split up are very enduring, and hence the common use of the tree in France, especially about old houses, for trellis-work against walls. The mean and ugly modern way of wiring a wall with galvanized wire is not so good as the old fashion of trellising with split Chestnut, often common as underwood in the very places where the wire is used. In forming a pergola, if we make our pillars of brick or Oak, and our main timbers of Oak or Larch, it is the best wood to form the smaller divisions, by which we mean rent Chestnut made from underwood growth. Chestnut wood is best when cut in the young and growing state, as old trees are apt to become shaky.

Fine as the tree is in parts of our own country, it does not attain to its greatest size on the northern side of the Alps; not till we have passed the mountain chain which separates Italy and Greece from central Europe 


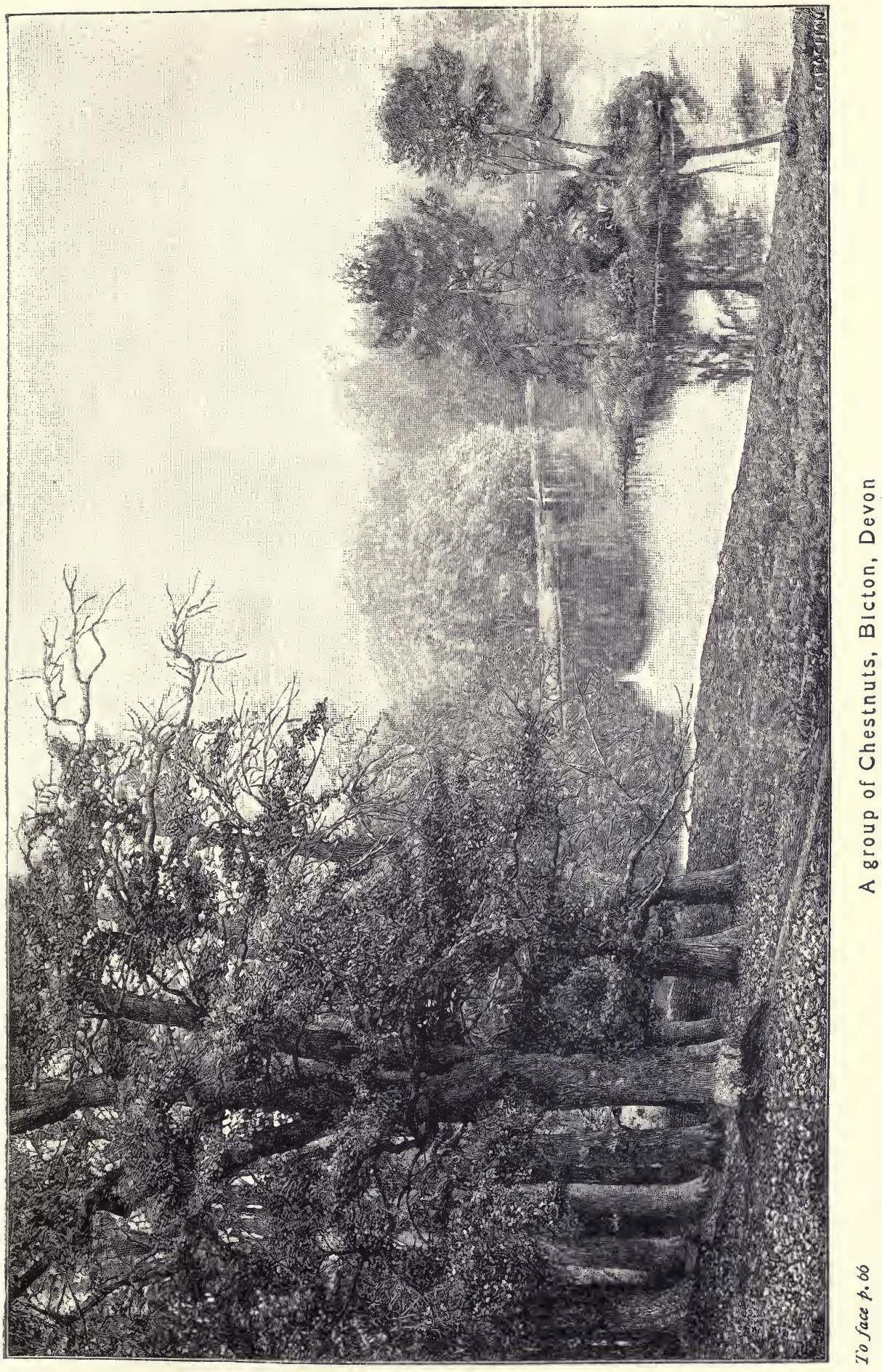


aingus 
do we see it in all its strength. On the southern slopes of this mountain chain, much finer trees than any in England or France begin to appear, and as the traveller goes southward he finds the Chestnut still increasing in size and beauty towards southern Italy and Sicily. There, in the lower girdle of woods, Cork trees and Evergreen Oaks prevail, often growing out of the lava; but in a higher zone of this woody girdle, at an elevation of between 3,000 and 4,000 feet, the Chestnut is the great tree. The elevation and the soil (consisting chiefly of ashes in an impalpable powder) suit it well, trees in that region being of gigantic growth, numbers of them far above the average size of the forest trees of Europe. The Chestnut will grow well on sandy or brashy slopes where Oak or Pine would fail.

The Hornbeam. This beautiful tree is one of the neglected children of the woods. Compared with some countries we have a limited tree flora, and it is therefore remarkable that any of our own trees should be so neglected by planters as the Hornbeam is.

It is a native of the southern parts of England, but not of Ireland or the north, and it inhabits a vast region in central and northern Europe and Asia. It is said to like a clay soil, but judging by its rarity in the heavy Wealden country south of London, it does not seem to like a compact soil, while it is abundant at Epping, on more open soil. Some coolness of soil is no doubt necessary to it. Free sandy loams suit it better than the compact soils of the Weald, nor does it care for very hot ground, any more than for marsh lands, or those of a peaty nature.

The finest Hornbeams seldom exceed 70 feet in height, with about the same spread of branch and a stem 
of 6 to 8 feet round. The natural form of the tree is often spoiled by pollarding. It is almost free from insect pests, resists the roughest winds, yields a grateful shade in summer, and is so hardy as not to fear the sharpest spring frosts. In northern Europe the Hornbeam is commonly found fringing the great Beech forests, in low-lying land where that tree is hardly secure in early spring.

The Wych or Mountain Elm. In this we have a tree of our own land and one of dignity and beauty, better seen with us than in any other country, though it occurs also in the northern parts of Europe and Asia. It is so abundant in Scotland and the north country as to bear the name of Scotch Elm, and though less common south of the Tweed, there are Elms in many parts of the country remarkable for their stature and picturesque form. The stiff outline and tapering column of the Field Elm gives place to a massive trunk often of vast girth, breaking into great limbs which are larger and wider spreading and carry a more massive crown of deep green, which usually falls in the autumn a little sooner. The branches are more or less drooping, falling into free and graceful forms rather than the trim roundness of many trees.

In Yorkshire it reaches its highest point in BritainI, 300 feet, and this moderate record is distanced by the Field Elm, which rises to I,500 feet amid the hills of Derbyshire. In the mountain forests of Switzerland and Germany it attains an elevation of 3,000 feet or a little more, but it is nowhere a high mountain tree, choosing rather the lower slopes and the steep moist banks through which the moisture from above finds its way to the rivers. 
While of fine effect in groups, the Wych Elm is not a good tree for mixed woods, where its spread of growth makes it a bad neighbour. The growth of young trees is very rapid, the long annual shoots being so flexible as to resist the fiercest storms and make it one of the best trees for wind-swept shores and exposed places. It is much less apt to fracture than the Field Elm, thriving well as a hedgerow tree and much less prolific of suckers. On poor land it is short-lived and not worth growing, and it fails completely on dry gravel or stiff clays, though it grows fairly well upon chalk and limestone. Rich alluvial soils suit it best and account for its majestic beauty in our parks and beside water; for though not classed as a water-side tree, some of the finest examples of Wych Elms are seen near water, the boughs always weeping in old trees which lean gracefully in all directions when grouped.

The Field Elm. The Field Elm is the most stately tree in the plains and valleys of Britain and western Europe, and one of the most frequent, owing to its easy increase and rapid growth, but one that in our country should never be planted, as it commonly is, in avenues, beside roads, or near houses and out-buildings. In such places it is much better to have firmly-rooted trees like the Ash, Beech, Oak, and Pine. With the Elm there is always the danger, even in fine weather, of boughs falling with fatal consequences to men or animals, and there is the disaster which results from heavy rain-storms and floods sweeping over the country, desolating whole valleys, and glutting the market with the trees blown down, so that fair prices are not realized. Of its value there can be no question, but the right place for the Elm is the heart of the wood, or in alluvial or free soils 
and loams, where one gets the best results, and it is quite out of harm's way. As a forest tree we should get its strength expressed in a bolder way than when isolated as it so often is, and it is also out of danger in groups in parks like Spetchley.

Though often low in price owing to the frequent falls of trees during storms, the wood of the Field Elm has good and varied uses, and may be and is often employed for purposes which generally the Oak is thought best for, as, for example, flooring and weather-boarding, being of better quality than that of the Mountain Elm.

The Elm is one of the most prolific of trees, scattering its seed freely, and therefore it is important in all cases of forest plantation to see that the trees come from seed, as the Elm suckers very freely, and there is the danger of getting suckers instead of seedlings. For this purpose good seedling trees of 3 to 4 feet high should be used. The rotation maturity of the Elm as a forest tree is from 80 to Ioo years, at which age it will have attained the dimensions that fit it for most usages. There is no merit and no profit in letting it get broken-backed and rotten to the heart as we see it about London.

No family has such a number of varieties as the Elm and none we stand less in need of. After our own two large native Elms, the smooth Elm, the American Elm, and the Rock Elm are the most worthy of a place in our plantations.

The Sycamore Maple. A beautiful northern tree, forgotten often by planters, perhaps by reason of its freedom to spring up from self-sown seed. So we often see it in a crowded state in shrubberies, and its fine form and stature is only revealed when we stand before such trees as those at Knole and at Penshurst. In many districts 


\section{of the Northern Forest}

of our country, where the soil is free and contains varied mineral constituents, like much of Ireland, Wales, and Scotland, the Sycamore increases rapidly ; but in nature it does not often, like the Oak and other trees, form pure woods, being often mixed with the mountain trees like Beech and Hornbeam, with which it has more in common as to area and soil. It loves diversified country more than the heavy soils of the Weald, and withstands storms and sea-winds very well, growing high in the Alps of Europe and Asia, and proving the best of summer-leafing trees for our storm-swept shores.

The tree has long been valued for its many uses, and had it been more widely planted, the woods on many estates would have gained in value.

It seeds so early and so abundantly, and the seedlings come up so thickly in woods, that the French foresters have come to regard it as the only tree likely to prove dangerous as a weed in a forest.

Numbers of large Sycamores are now used in Yorkshire and Lancashire, and the finer butts are frequently sold at high prices and carried hundreds of miles.

The Sycamore does well close-planted, increases very fast in trunk volume, equals the Oak, Ash, or Elm in value up to middle age, and after that exceeds most other trees in value.

There are several distinct forms-the common greenleaved kind, the purple-leaved with dark-green leaves and purplish-red veins and footstalks. The purple variety is common in Scotland, and is, if anything, the most vigorous grower of the four. All succeed in wellnigh any soil or situation, north and south, but they grow best in deep moist land if not water-logged, moisture at the root being of more importance than 
a rich soil. Fine trees are none the less found in high and exposed situations on dry rocky soils, and however much exposed, such trees are rarely injured by gales. The Sycamore is more abundant in the north of England, in Scotland, and in Wales, than in the south country.

Among the kinds of Maples which have been tried the best for our country would seem to be the Norway Maple; but it is a large family and some Maples may in time be found worthy of the name of finest trees for our country.

The Birch. This is not among the most important trees for the high forest, and as it often sows itself in our woods we need trouble ourselves less about it, except where beauty is concerned. The effect of the large Birches, grown in pure woods of them in North Germany, is one of the most beautiful of woodland effects. Among the greater, or tree Birches, after our own (including its varieties or allies), are the Canoe Birch; Paper Birch, a forest tree of northern America, which is hardy in Britain; the River Birch, also a tall tree of northern America; the Sweet Birch (Betula lenta), the Yellow Birch, sometimes roo feet high.

The Maidenhair tree (Ginkgo biloba). From whatever point of view regarded, this is one of the most mysterious, beautiful, and distinct of hardy trees. True the tree is common enough in the Far East, where it is said to have spread from China to Japan with the Buddhist faith many centuries ago, and is now frequent in temple gardens and valued for its fruit. Eastern travellers also tell of Ginkgoes measuring up to 40 feet round and of a great age, to be seen here and there in the interior of Northern China, but these are all under cultivation, and if yet existing as a wild tree it must be amid the mountain 
fastnesses of Mongolia and Manchuria, the vegetation of which remains in a great measure unknown.

The Ginkgo is beautiful at all seasons in its erect and graceful habit, with widely-spaced limbs at first rising but when mature gently drooping in wide spreading curves. Its appearance is always impressive, the more so in early autumn, when the entire tree takes a golden tinge. When old it sometimes exceeds roo feet in height, with a trunk several feet in diameter covered with rough grey bark, deeply fissured. The flowers are not showy, but the fruits, borne freely upon fertile trees, are conspicuous and like a small yellow plum, consisting of a pulpy evil-smelling envelope of rancid flavour, surrounding a sweetish kernel like that of the Almond and not unpleasant to taste.

Hardy throughout the south of Britain, its growth is at first rapid when under the best conditions, but it is long in reaching maturity, and even the oldest plants in Europe have yet to attain their maximum growth.

When a tree is rare or uncommon it often gets into a staggy state in the nursery, and its increase by layers or cuttings is also against success. We can never get a fine tree in that way, and cutting propagators have done much harm to forest trees. There is not the slightest need for these practices, because, apart from the abundance of seed yielded by the tree in its own country, it seeds freely in the south of Europe. A hindrance to success is placing the tree isolated on Grass (which gets all the moisture) or in a hungry shrubbery. The conditions to ensure success are above all things to get healthy seedling trees, not too large, and for position choose a vale in a sheltered wood; put enough plants in, i. e. do not depend on one or two trees, but plant a bold 
group or colony, so that one can take choice of the strongest as they grow up, putting Larch or other trees between them at first to keep the ground cool, though these can be removed in due time.

The Bald Cypress. This beautiful hardy tree is in our country too often treated as 'ornamental' only, and frequently ill-placed at that, so that in many country places usually it comes to little. Many years ago, before the taste for Californian conifers arose, it was planted more frequently, and so we see in some valley gardens stately trees of it, mostly by or near water. About the time our own people were busy planting the tree many were planted in the north and west of France, and in the valleys of the Loire and the Seine beautiful examples may be seen, some over roo feet high. Near Orleans there lived once a nurseryman having some fine trees of this on his ground, who left his property to some good Sisters in the town on condition that they should always preserve his Cypress trees. The ground that was once a nursery is now a grazing plot, adorned with several stately trees standing up over their surroundings as distinctly as the great church of Orleans towers above the houses around, their stems like enormous pillars, beautiful in colour and form. They are not beside water, but on a rich bottom.

It is not necessary to have a river bank on which to plant, though very often that is the best position, as rivers carry down deep soil. But that may occur without the immediate presence of water, and wherever there is this deep, moist, and free soil, we may in our country hope for success with this tree. Having proof of its hardiness, fine form, and great size, we should give up the practice of regarding it as an 'ornamental ' tree only, 
and mass it in likely places where we shall eventually get its true forest aspect-one of the noblest in the northern world. By so doing it by no means follows that we lose its beauty, and the fresh, distinct effect of the foliage is good in all conditions where the tree thrives. The habit of propagating this tree from cuttings may be one cause of its failure. It should always be raised from seed and planted young, the younger the better provided rabbits are kept out by well-supported netting. The presence of water does not assure us of a good result, as some artificial waters are formed in poor or cold, impervious soils.

The English name of this tree, 'Deciduous Cypress,' is not a good one, and I follow the accepted American name of 'Bald Cypress'.

There are worthless varieties of the Bald Cypress of no garden value and often offered under false names (i.e. Glyptostrobus) which serve only to throw pseudo-botanical dust in people's eyes. These distortions should be avoided by all who wish to realize the beauty and dignity of the tree. The true way to a fine result is to grow it from seed of the wild tree, which germinates readily in a few weeks, and growing it in the best natural conditions. Like most trees of the Pine order it has a tendency to vary in its branchlets, and for nurserymen to seize such bits, and increase and name them, is to do much harm to the interest of good planting, especially to those beginners to whom a ponderous Latin name may seem to represent a real tree and not a wretched 'sport'.

The Tulip tree. Although it may never attain in our country to the dimensions of those in its native land, this is a tree of proved value; and though not planted as a forest tree should be, among its fellows in woods, 
still it attains striking development in many of our country seats, as in the example at Esher Place. The fact that, fully exposed as the trees are, in pleasure grounds and lawns, and with the roots robbed by the grass, they yet attain this size, proves that, planted and grouped in a more natural way, we ought to get an even finer growth. Any free soil suits it, if deep and fresh without being wet. It grows faster than many forest trees, is free from insect pests, beautiful in flower, and excellent as timber. To do well it should be planted young and left to itself, being averse to removal or cutting.

Hickories and Walnuts. Of all interesting trees the most neglected perhaps in our country are the American Hickories and the Walnuts. More often seen in France than in England, the Hickories are tall graceful trees allied to the Walnuts, which are also very important trees. But perhaps these trees come more under the head of experimental planting in our country, and one should make a moderate beginning and in a good soil. The Black Walnut is a very free-growing tree in our country, and there are other important kinds worth trying. 


\section{CHAPTER VI}

NATIVE AND EUROPEAN TREES BEST FOR OUR ISLANDS

IF we have eyes for the highest beauty in tree-life, we may find that after looking for it round the world and having gone through all the books and pictures of Californian and other giant trees, we may have to seek for it at home among the trees of Europe and Britain. But we live in a time when the pursuit of things exotic is so active that the value of native trees is often forgotten. We see in books of much show of learning, like Brown's 'Forester', trees named as being fit for forest work in Britain which are not only of no proved value, but even require a greenhouse to live in, like the Norfolk Island Pine. Catalogues, too, nourish the delusion that we must look to other lands for all our good things, and we see men planting many costly and useless trees who never plant native trees. Wretched plantations these costly exotic trees often make, as all may see who watch them for a few years. While with the native tree on a suitable soil there is no going back, with the foreigner all is risk.

It is not a matter of hardiness only; a tree may be as hardy as the Spruce on the mountains of central Europe, and yet do poorly in southern England. The native tree is ready to respond to every impulse of the season, is happy with our rainfall-often a-slight one in some districts-and, given the soil right for it, soon makes in growth an end of all the pretensions of exotic rivals. Soil and right situation every tree must have; the rock 
from which springs the column of the Pine will do nothing for the Oak, and any tree, native or exotic, is profitless and often ugly on ground that does not suit it.

Wood value. For quality and value of wood the native tree is by far the best. Nothing else that can be done with the land that suits our native Oak will pay so well with so little labour. The natural Beech woods of Normandy and Britain are among those that more than repay the owners. No foreign tree we grow, except the Larch, now stricken in many districts by a disease which threatens to make it useless for us, equals in value the wood of our Oak, Ash, and Tree Willows. The facility of increase of our native trees should also be thought of; and it is clear from what we may see in a neglected field that the Wealden land in Kent or Sussex would soon be a forest of Oak if let alone. If we plant Pines in an arable field that has been under the plough for years, we shall probably find Ash, Oak, and Birch, sown by squirrels, mice, or winds, starting up here and there and keeping pace with the quickest growing Pines. But it is not only the value as timber of our native trees I wish to show, it is their beauty; no trees introduced from other countries equal in that our native ones, with the exception of the Cedar of Lebanon. In many districts there are no natural old woods where our native trees can be seen in their forest forms; but the beauty exists for all who care to see it, and in many ways. What various forms the Oak assumes in chase, or park, or wood, and perhaps most impressively in old Oak woods, where the trees stand tall and close. The tree varies in different countries; such stately Oaks as we may see by the roadside in Warwickshire we never see south of London, where 


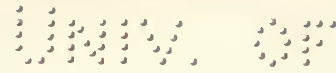

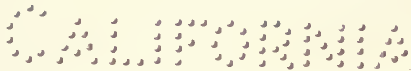

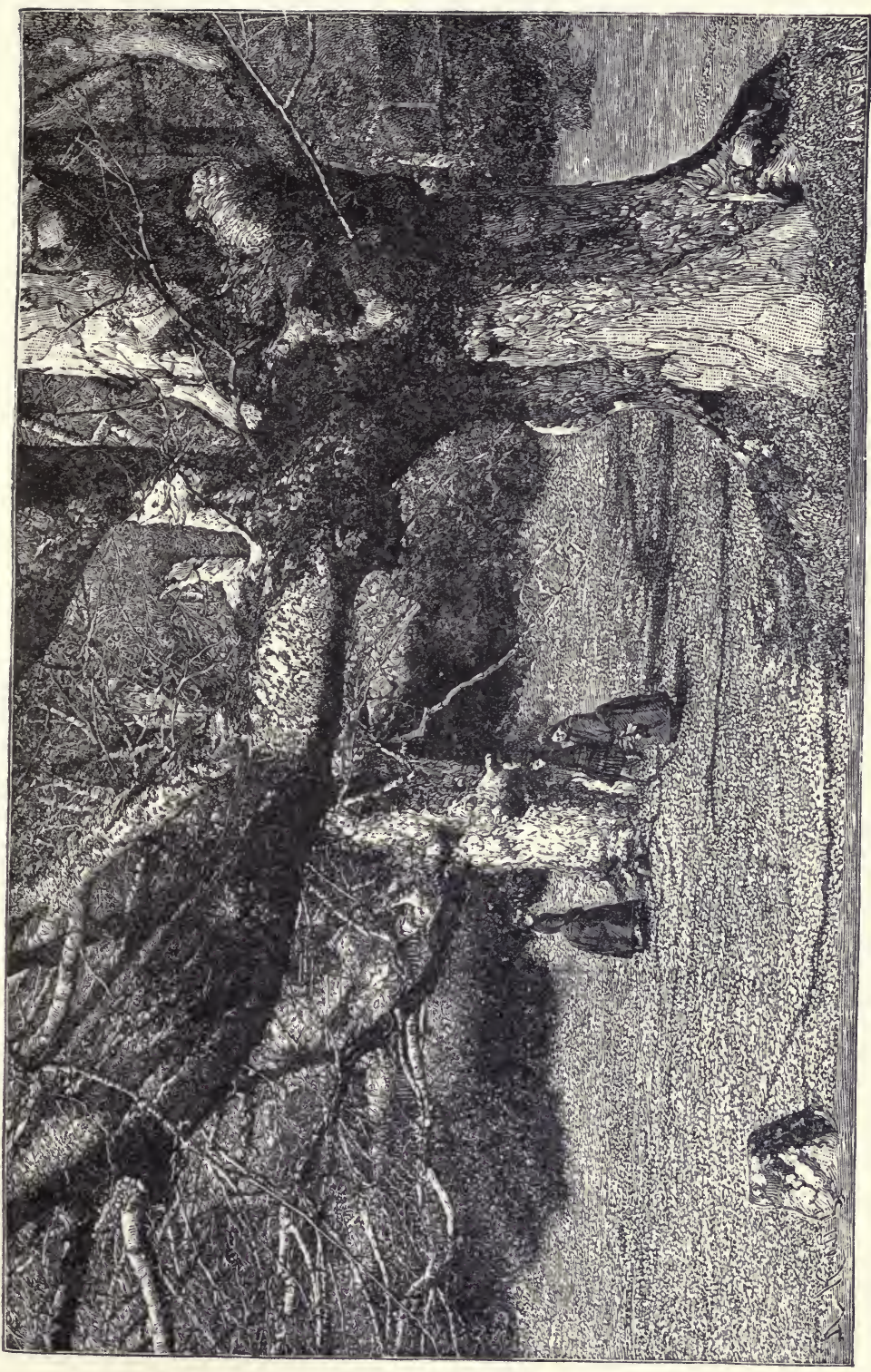

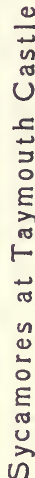

옹

i

ళ

i 


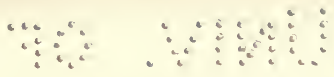

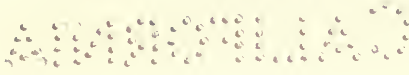


there are many Oaks in many forms. So, too, the Beech, a true northern tree in its vigour; how fine it is in many conditions-on chalky hills and also in the level land, whether in Surrey or on the Lothians. The Ash -one of our best timber trees-is often fine in form in old states. There is a whole string of Elms and their varieties in catalogues, but by far the best is our native Wych or Mountain Elm; a noble tree in beauty and dignity, attaining sometimes a girth of trunk nearly, or quite, 50 feet and a height of 120 feet. Our native Poplars are often neglected, the Abele and Grey Poplars being stately trees, and the wood more valuable than it used to be. Among Pines, we have none which surpasses our native Fir in form and colour; when old, valuable, too, for timber. The Field Maple is a neglected tree, but beautiful trees of it can be seen here and there in woods, as at Mereworth and Brede. The Sycamore Maple is fine in form, as we may see at Knole and other places. It is supposed to be a naturalized rather than a native tree, but over a large area of the coldest parts of Europe no tree surpasses it in vigour and rapidity of increase. It is storm-resisting, thrives near the sea, as in Anglesey, and is altogether one of the best trees for planting.

Tree Willows. The Tree Willows of Britain have value as timber, but are neglected by planters even of gardens, though none of the variegated rubbish of the nursery gives anything like so good an effect as the White, Red, and Yellow Willows in winter or summer. The Common Lime is not a native of Britain, but two other kinds (Tilia cordata and T. platyphyllos) belong to our native flora. The Hornbeam is a true native, neglected by planters, though common in some old 
woods. The Yew should never be forgotten in woodland, where its shelter for game is welcome. It is too much planted near houses, to the danger of animals and to the loss of all good flower gardening, owing to its roots. The Holly, usually in gardens a shrub, is on the hills and in land that it likes a tree 40 feet high, and therefore never to be omitted in seeking evergreen effect.

Trees for beauty. Trees of secondary value as timber are often of great value for their beauty, and should never be forgotten by planters with that hope. Thus Crab, Hawthorn, Aspen, White Beam, Wild Cherry, Bird Cherry (often a fine tree, as at Longleat), Mountain Ash, Wild Pear (the Pear in good deep soil, as in Worcestershire, is a forest tree, and a very fine one), and the Wild Service Tree with its finely coloured foliage in autumn, though rarely planted and only here and there seen so well as at Blackdown. The Crab is as handsome as any flowering tree; the Alder gives us good colour by the streams in spring. The Mountain Ash, or Rowan, is really deserving the epithet splendid when it is grouped on the hills, or almost anywhere else; but it is beloved by the rabbit, and many I have planted in the hope of adding its fine colour in autumn to old woodland have been all gnawed round and destroyed. On rocky ground it is lovely, where it takes various dwarf forms. The White Beam is an effective tree at various seasons and well deserves to be made more of, as also its varieties or hybrids (like Prunus latifolia). Some of the trees we admire individually are not so often seen grouped, though there is nothing more beautiful than a free group of Aspens on a limestone soil in autumn. Birch, too, which we often see in the 
north of Germany, with the white stems rising like silver columns all round, might be more often effectively grouped. Nor is any introduced tree so fine in form when grouped as the Ash, as one often sees it round a farm-house on the hills or in the north.

In all the changes of fashion as to trees there never was one in which people were so carried away as by planting the giant conifers of Mexico and California, nor one in which failure has been so complete. And we have not only to suffer the loss of these trees, but there is the penalty of our neglecting the trees of the forest plain, from Oaks to Maples, which are far more suited for a lowland country than the conifers of those lovely mountains fanned by Pacific Ocean breezes. Similarity of climate is what we should always remember, and the more like the climate of our own country, the more certain success will be. The region of the Corsican Pine, and that of the Cedars of North Africa, is so high in altitude that it has somewhat the same conditions of climate as our own country, the proof being that we see our own hardy wild flowers and shrubs growing there among the Cedars. Our aim should be not the increase of kinds, but making good and artistic use of those that not only endure but thrive in our climate. Hardiness is only one of the conditions, as the hardiest trees may fail.

If these pleas for the first place in our work being given to the trees of Europe and adjacent regions of Asia and North Africa have any value for the southern and warmer parts of our islands, they will apply with greater force to cold midland and northern districts where only really hardy things thrive. And it is worth remembering that apparent health in youth is not always a proof that the tree will prove of lasting value. 


\section{CHAPTER VII \\ WOOD AND COVERT FROM SEED}

THE free way in which trees sow themselves should lead us to think of the advantages of sowing the seeds of some trees direct where they are to grow as a wood. Perhaps in planting with Pine an arable field in which a tree has not grown for ages, among the young Pines we may find young Ash trees and clean young saplings of the Oak brought thither by squirrels, birds, or mice. The Scotch Fir sows itself rapidly in heaths and rough lands in Surrey, Devon, and Hants, and many other places; Larch we may see come up on poor soilless railway banks. Sycamore comes up thickly, and, though not now a tree much planted, is a valuable one in many ways. Chestnuts are more easily raised from seed than in any other way, by dibbling in the nuts. The squirrel, long-tailed bank mouse, the bank vole, the jay, and the rook are among the living things that bring and scatter the seeds of Oak and other trees for us.

Our reasons for sowing direct are various; plants for forest work are not easy to get in many districts, planting trees too large is fatal to success. As the ordinary nursery does not always lend itself to the cultivation of forest plants in the best state for woodland planting, nurserymen often have to apply to other growers for them, and hence a double movement of the plants, often to their injury. Unless, moreover, the ground is ready, the plants suffer after getting home. The best results 
are from little trees, say under a foot high generally, but during hot years, in the southern and midland counties, failures are common, even of sound little trees. Planting as usually done is expensive. This is especially so if the work is not organized by a woodman, who knows what to do and how promptly planting should be done. Every trade has its routine way, which is not always the best way for the buyer, and is often nothing more than a trade convenience. Sowing trees is a most interesting way, it is also the natural way, and my experience is much in favour of seedling trees as against planted trees; and those who have poor fields might sow them with tree seeds, getting sound seed, and from good sources. The sowing of trees may be done in different ways according to the soil, the trees chosen, and the labour at our disposal. It may be done broadcast, and not a bad way in good Oak land is to scatter acorns over the ground and then run a light plough over it, which throws them into lines and also preserves the acorns from their numerous enemies during the winter. Acorns may be dibbled with success in the underwood also. Chestnuts may be planted in the same way. Bare rocky surfaces may be sown broadcast. These remarks apply to native trees and such hardy forest trees as readily take to our climate, and of which sound seed is either at hand, as in the case of Oak, Ash, and Sycamore, or to be obtained from a good seed house.

Sowing covert direct. If in any bold or varied planting in unfamiliar soil we succeed in one half what we attempt we are fortunate; and I think the best thing I ever did in planting was sowing a bare field of some seven acres with Gorse. It was about to be planted- 
some part was, in fact, already partly planted-with little forest trees, when I scattered the seed broadcast over the field. The field was wired and rabbits kept out, and after five or six years the effect of the Gorse, with the young Pines and Larch growing up and standing a little above it, was good. The warm colour of Gorse as a covert in winter is pleasant. Where is there another shrub that does so much for us? In old woods it has less chance owing to the rabbits and partly to shade. On railway banks, or bleak, dry, 'brashy' places, it thrives and looks at home. Where in clearing fences or old fields a difference of level often occurs-the result of ages of ploughing-it is a good plan to sow Furze on the little rough terraces. There would be no particular advantage in seeking this Furze treasure where the bush abounds, as in many parts of Ireland, Cornwall, and Devon; but where it is not common it is one of the best covert bushes one could raise.

As to sowing among young forest trees, I simply take advantage of the spaces between them, and, instead of the Furze being a hindrance to the young trees, it is a gain, inasmuch as the Furze thickly planted is a soilmaker, its leaves falling thickly, and the rapid-growing Pines, closely planted, as they ought always to be, will, after some years, get clean above it and finally get the field to themselves. In making the best of fences, the live fence, Furze seed scattered along the banks comes up very soon; it looks very beautiful in such places, and helps to make the fence a more sheltering, dividing line. As so many are particular about the time they sow or plant anything, I may say that there is nothing to be gained by sowing such seeds early. A very good time is in April, when the nightingale comes, May, or early 
in June ; and, as there is no covering or transplanting, it does not much matter if the seeds are sown at night. It must not, however, be thought an altogether haphazard business, because the man with the seed bag is supposed to know his plants and the places that are likely to suit them. Furze seed is sold at a low price by all the great seed houses of Europe if bought in any quantity. Other kinds of Furze I have tried in like ways, and find that the tall one known as the Foxbrush (Ulex strictus) does equally well. It is a very rapid grower and a fine, useful aid for the farm, as it faggots more compactly than any other Furze. Much less vigorous than this is the dwarf Furze (U.nanus), which abounds in rough heaths in many parts of the country. It thrives and looks well sown in places where a compacter growth is wanted, it is as free and easy as any, and may be sown just in the same way. The dwarf Furze is beautiful in autumn when all the other bushes are losing their charms, and best for low foregrounds and rather bare, sandy, and stony places.

The Brooms. I never fancied these so much as the Furzes, owing to their scraggy habit (when old) not forming such good covert, though they are beautiful. The best, the Spanish Broom (Spartium junceum), flowers much later than the others, and is a showy, handsome plant, growing on any gravelly or sandy place, no matter how dry. I saw no place so suitable for this as a railway bank near, so standing on the top of the bank I scattered the seed and let it fall on a steep slope formed of débris and with no soil. The natural soil of the place is about as poor as any on earth-simply shaly rock-and the bank was overrun by rabbits. After some time the Spanish Broom began to show itself. 
I was encouraged to sow more in spite of the rabbits, and there are now thousands of bushes on this waterless, soilless bank, and a beautiful bloom comes in midsummer after most of the flowering shrubs are past, the effect being good as far as it can be seen. Our native Broom (Cytisus scoparius) is a very beautiful plant, though it does not make such good covert as the Furze. It is very graceful where it grows here and there in quarries or rough, stony places. The Portuguese (or White) Broom (C. albus) is a graceful bush and comes freely from seed, which should be sown in sandy, warm places. Sow early in June. One of my reasons for sowing the seeds of these things is the difficulty of transplanting them if not bought very young, and even then they often fail. Besides, there is the expense of transplanting and no end of labour entirely got rid of by bold sowing, and my friends and myself see better effects from this work, simple as it is, than has been got in other ways with many times the expense and labour. In garden culture it would often repay to slightly cover the seed, and in sowing small pieces it would be safer to do so; but in dealing with various rough surfaces about a country place, and using seed freely, it is not necessary.

In the autumn of I903, acorns being plentiful, I sowed a field with them, using the plough. They came up well, too thickly, and we lost two or three years in growth by neglecting to keep out rabbits. In spite of that the roots eventually became the masters, and by the summer of 1906 we had a vigorous Oak wood. Excluding ground game one might then hope to raise on cool ground a thriving young Oak wood in twelve years.

A better way than mine, if there be the time to carry 
it out, would be to dibble in acorns at about 4 feet apart in lines each way (all the better if we gather acorns from some famous or fine trees) and wire against rabbits. Then when the acorns come up plant a little Larch between each two baby Oaks to act as nurses, and to be cut away in good time. In this case we might hope for a good result, all the more so if the soil were too stiff for profitable use as arable. 


\section{CHAPTER VIII}

\section{EVERGREEN COVERT}

THERE is nothing about which there is more loose talk than in the matter of covert plants. One famous sportsman tells people to put Privet where they want covert near water - a most weedy and evil-smelling shrub, besides bad covert, its rapid growth being its only recommendation. It is a mistake to use a weedy bush merely because it grows quickly. Most hardy shrubs grow quickly enough, and some of the most rampant growths are the soonest to go back. On the whole, the best covert plants, especially for woods near the house, are the native and other hardy evergreens. In the choice of such plants their beauty should not be overlooked, and things of offensive odour and other bad qualities like the Privet should be rejected.

Rhododendrons. There is a shrub which is hardy and beautiful as an evergreen covert plant, fine in colour, and of vigorous constitution. It is 'Cunningham's White', an old kind which, although called white, is a rosy-lilac colour in bud. It is one of the best plants for growing in any cold, or rough, or even clay soil, forming far better covert than the pontic Rhododendron, and having also the advantage that it can be bought on its natural root in some nurseries. It is easily increased, and grows in any soil. I have had a healthy group of it in clay (part of the dug-out foundation of a building) for over 
a dozen years; it never turns a leaf in any frost, and is a close and excellent covert.

Rhododendrons are often planted, but it is the common pontic kind, which, used as a stock, ends by killing the good kinds grafted on it. If, however, we take to layering our brilliant kinds of hardy Rhododendrons, then we shall have such underwood effect as no garden can rival. It is not necessary to put the finer and hardier Rhododendrons, raised mostly from the hardy North America kinds, on the somewhat tender ponticum, and, if nurserymen will not layer them, every one who has a good kind should layer it for himself wherever the plant grows. Some of the best nurseries now have already good stocks of the finer kinds on their own roots, and are preparing more. These in cool woods would almost layer themselves, and give a splendour of colour in summer that no man's planting could surpass.

Box. There is no more useful evergreen covert than this for chalky, light, and warm soils, and for growing where it would be hard to establish covert from foreign shrubs. Few who only see Box weary and drawn in the shrubbery have any idea of its beauty massed on an open down. As an evergreen group on a hot and poor bluff in a wood it is fine in effect, and an excellent and warm covert. Happily, this native evergreen loves our poorest and driest soils, of which there is such a vast area in the southern counties. Box will thrive on chalky wastes where no other shrub appears, and, fortunately, it is so distasteful to rabbits that it is let alone in places infested by them.

The Evergreen Barberry (Berberis Aquifolium). This is a pretty evergreen, and a free grower in many peaty, open soils, but not so free in certain heavy soils: As, 
however; these occur in certain parts of the country only, it may be included among the very best shrubs for evergreen covert.

The 'Sweet Bay', or True Laurel (Laurus nobilis). I had never seen this used as covert, but having many bushes of it to spare I tried it in old woodland, and was pleased to see how well it looked. It is very cheery in colour in the winter season, and it grows very freely in southern and seashore districts. Even if not generally used as covert it can be made to form very pretty groups in woods, but rabbits soon destroy young plants of it if not wired.

Juniper. Our native kind is meant here; it makes very good covert for the poor, dry, and chalky soils too frequent in the southern half of the country. Junipers can be had from various parts of the world, but our own native Juniper is as worthy of cultivation for this purpose as any, and we have so few really hardy evergreens. In the valleys in Surrey it grows to a height of 18 to 24 feet, though usually only a bush.

Savin (Juniperus sabina). This is one of the most graceful and hardy of all dwarf evergreens, and admirable for cold hills or stony ground, no matter how wet or poor. It is a dwarf Juniper that clothes those parts of the mountains of central Europe too bare to support anything larger. If not easily bought in quantity it can be readily increased by pulling up the branches, which often throw out many rootlets. These should be planted firmly and a stone put over the part left out of the ground, or it can be pegged down to stop wind-waving.

Ivy. This is undervalued for its use and beauty in woods, and is too often cut away. It would be well, in many places where the large-leaved Ivies are grown, to 
put them here and there in copses. They are of all things the most easy to increase, the young shoots pulled off wall or tree rapidly rooting in moist earth. The Ivy is among our best native evergreens, as, after carpeting the wood and clothing the tree-stems, it takes the tree form, and is as good an evergreen as any.

The Great Partridge Berry (Gaultheria Shallon). A valuable covert bush, difficult to obtain in many nurseries owing to the small demand for it. It will thrive in ordinary soils and runs about apace in wet peaty places. In Scotland it seems to be better known than in the south, for it has been largely planted there for covert, as at Balmoral. It is one of the shrubs that will thrive in the shade of Pine plantations, and is in all ways excellent.

The Cherry and Portugal Laurels. The Cherry Laurel (usually, but wrongly, called the Laurel) is, perhaps, more used than any other bush, but has certain defects, being not hardy in severe winters even in Ireland, and also, it is too vigorous for underwood covert, and when chopped back, as it very frequently has to be, it is ugly. Some of the newer forms, however, are hardy, especially that from the Shipka Pass; and its beauty is best seen in a wood allowed to grow in its own natural way. In some southern and mild districts the Portugal Laurel and some of its handsome forms are very free-growing, but in cold and inland districts they are apt to be cut down in hard winters. They are so free and handsome in the south and west, however, that they may be used with good effect.

Yew grows well in the shade, and gives warm covert, but should only be put in the interior of woods owing to its poisonous nature, and the woods should be fenced 
or much trouble may arise from stock eating it. It is naturally common in some districts, and cannot be excluded from our plantings, and the safest way with it, perhaps, is to put it in a dense group towards the centre of a wood, where its shelter will be very welcome to birds in winter.

The Palmate Bamboo (Bambusa palmata). I first had this in a moist wood in rather black soil, and then took a fancy to moving it to the water-side, and although we took the plant out carefully from the wood, a number of roots remained, and from these arose the most graceful colony of plants I ever saw, so fresh and fine a green in the middle of winter as almost to make one forget the season; the shoots are handsome enough to cut for the house in winter, the growth close, and the form good. It was also quite free by the water-side, where its fine reed-like habit goes well with Reeds and Willows.

The Japanese Bamboo (B. Metake). This is very free and hardy in varied conditions, and a fine covert plant. It has long been cultivated in Surrey nurseries, and is easy to secure; it increases quite freely either in woodland or near water. Some of the older Bamboos, such as used to be grown first of all, as B. falcata so well in the south of Ireland at Fota, give tall covert of a graceful sort, but not so good as these.

$A$ beautiful evergreen covert plant. We often see lists given in catalogues of covert plants, like Privets, which are only of slight beauty and value, and inferior to our native Briers, Bracken, and Furze as covert plants. There is one bush, however, not always known as a native be it said, which makes the most beautiful of all evergreen covert, especially in sandy, chalky, stony, or dry gravelly soils, where few other things will thrive. 


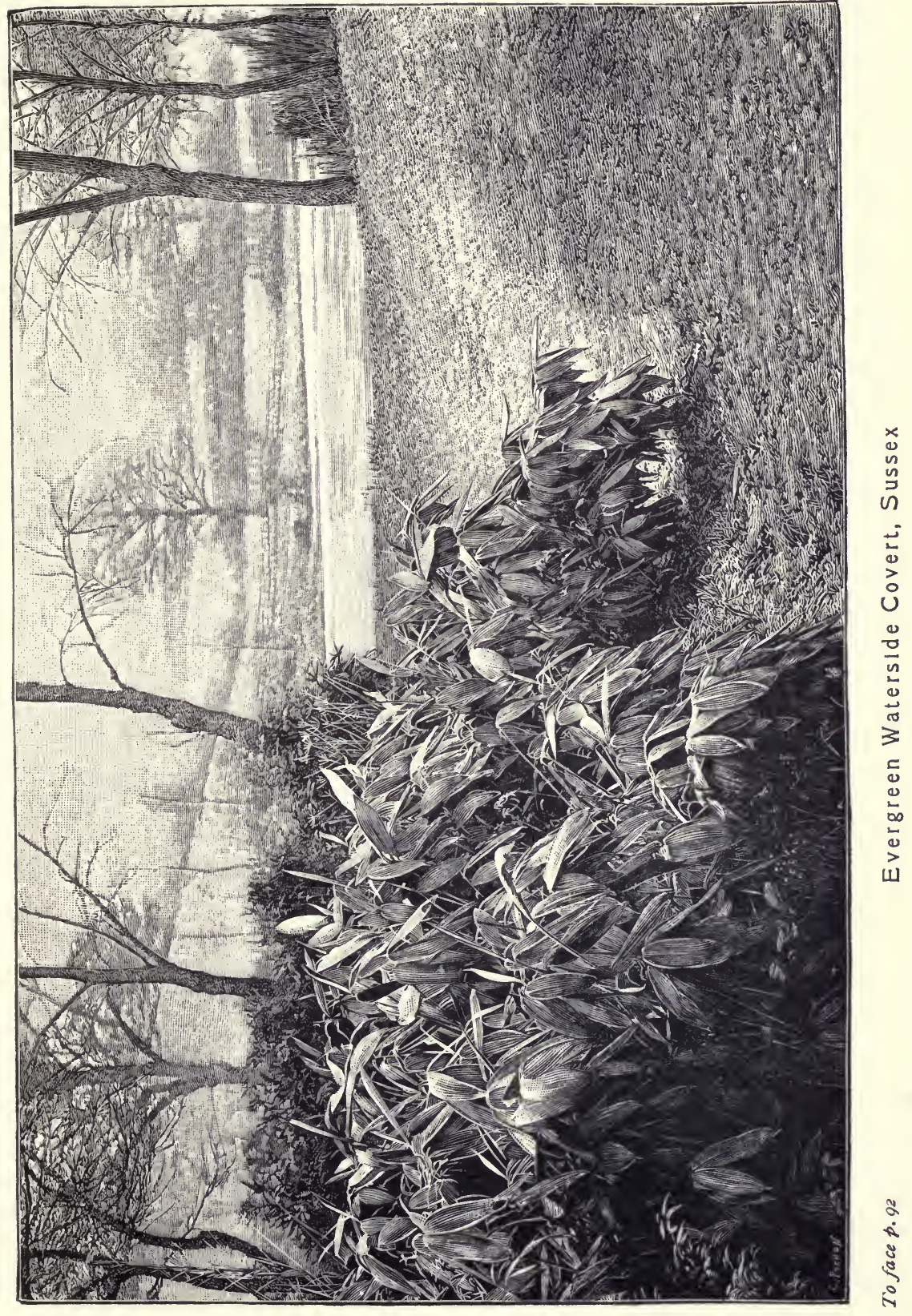




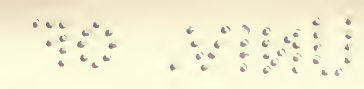


The Box is common in shrubberies, but is rarely seen in its natural form of a spreading plumy bush on an open sunny hill-side. I know nothing more beautiful among evergreens than Box-trees fully exposed, as there they have a charm never seen in 'shrubberies'. A great quality, and one which raises it entirely in value above Laurels and the other evergreens commonly used for this purpose, is that rabbits do not touch it, owing to some poisonous property. In the last two years, in the hope of getting some evergreen covert, I tried the hardiest form of the Cherry Laurel, and also (a great favourite of mine) the true Laurel or Sweet Bay; though accustomed to the depredations of the rabbit, I never saw anything so sad as the disappearance of both, many plants being absolutely bitten to the ground, whilst in the same woods Box of all sizes remains untouched. For this reason above all, as well as for reasons of shelter, pleasant colour, and hardiness, it should take the first place among evergreen covert plants. There is a vast range of our country in which it grows well: and even where compact soils abound-which it dislikes-it is often possible to find patches of gravel or sand in which it will thrive. It is at home on arid soils and on hillsides and mountain slopes; large tracts of forest are covered by it in southern and western France and other parts of southern Europe, northern Africa, and northern and western Asia; it is also found in some of our southern and western counties-Kent, Surrey, Sussex, and Gloucester. Long-living and slow-growing as it is, it will, in the best conditions, rise to a height of 20 feet or over, and sometimes be as much as 6 feet round the stem. But grand specimens like these are the exception, and most often it is seen as a compact 
shrub. It is easy to establish or move at any age, but for covert use is best small, when it can be bought very cheaply. It seeds freely in our country, and on arid slopes might be increased by scattering the seed on the surface. To many the odour of Box is agreeable, and its colour also is very beautiful.

Hedges and shelters of Holly. Our country is fortunate in having as a wild tree the most beautiful evergreen of western Europe, and one denied to much of the country in central and northern Europe and a vast region in North America, where it will not withstand the winters. In beauty other evergreen Hollies are inferior to it, hence its berried branches are sent in quantities to North America at Christmas. Of all possible living evergreen fences the best is Holly in close but not stiffly clipped lines. Better still is the free unclipped Holly hedge, as it makes a fine shelter as well as a good background. In Warwickshire and other counties it often makes as good a shelter round fields as any shed. Of the clipped Holly hedges fine examples are at Woolverstone in Suffolk. Where land is not valuable-either from its poverty or elevation or other reasons-it matters little whether the hedge is clipped or not, especially round woodland and for cutting off woods from pasture fields. For such a case the finest hedge is that of unclipped Holly, because then we get its fruit and protection and fine form. Such hedges might be either of Holly alone or mixed with Sloe or Quick. Where from the nature of the soil it is not easy to raise Hollies from seed-as they should have friable open ground in the young state-it is best to buy small plants from the forest nurseries. The worst enemy of the Holly hedge is the rabbit. I have lost thousands of plants in that way, and 
although many places are not so much infested, still great care must be taken, or in hard winters the Hollies are sure to be destroyed. Where Holly comes naturally, as it does in many parts of the country, the destruction is not noticeable except after hard winters, when even old woods of it are destroyed. Being a close-growing shrub it forms a shelter for cattle, and as it grows much better than the Hawthorn under hedgerow trees it ought to be more often used for enclosing meadows and pastures. It keeps itself almost free from weeds, owing to the closeness of its branches at the bottom, and it is free from insects. Holly is found flourishing on dry gravelly land as well as on strong clay, but sandy loams are the soils it delights in most. 


\section{CHAPTER IX}

\section{UNDERPLANTING}

IN the present state of our woodlands, when through the decay of the trade in underwood and the neglect of the trees many woods are thin and worn out, "underplanting' should be thought of. Pines, that in youth might have covered the earth with their branches, have grown and shed most of their boughs, and Grass has begun to invade the ground, bringing in its train starvation to the trees, the sun and drying winds completing the ruin of the unsheltered woodland. Now this cannot happen if a wood is managed in the best forest way, which never allows the overhead canopy to be broken. The thin, scraggy plantations, so common by British roadsides and fields, are more open to the attacks of sun and drying winds than the broad, natural woodlands in the best planted counties and estates. The remedy for the stale woodland is 'underplanting'. That means, when woods get thin from any cause, the introducing of young trees, usually of other kinds and what are called 'shade bearers'.

In replanting old woodlands we must choose trees which will thrive in partial shade; and as in old woodland it is difficult to protect young trees from rabbits, we must, if we can, choose those that are not so loved of that pest. Where the nakedness of the wood occurs in large patches we can plant and wire, but in large woodland areas we must plant the young trees singly near 
the older trees, and hence the necessity for choosing kinds that will thrive in partial shade. Among the summer-leafing trees the best for underplanting is the Beech, of which in certain forests of the north of Europe trees of 50 to 60 feet may be seen thriving under Pines nearly roo feet high, and both close set. Interaction of the roots of trees of different kinds is rather beneficial than otherwise. After the Beech may be named the Hornbeam, Oak, Ash, and, on sandy or rocky soils, the Chestnut (not the Horse Chestnut, which is not a Chestnut at all). Most of the trees named-except the Ash-are not very subject to the attacks of rabbits, and they also bear planting as saplings of 7 to 9 feet, though beyond that size it is risky. In all cases we must avoid trees too old for transplanting. We cannot with success plant Pines of large size, but with a little care in buying from forest nurseries we can get tall saplings of the summer-leafing trees that will grow well.

Among Firs the best for underplanting is the Silver Fir, which may often be seen in the German forests growing well under the other trees, all closely set. Spruce, in wet land, is also good; and in our southern and western country the Douglas Fir is excellent and soon gets its head up among the other trees, the shelter of which is a help to it at first. Yew too is useful.

The effect of underplanting in the best cases is excellent, and woods treated in this way can be very beautiful, varied, and full of life; but in order to enjoy such woods well-considered rides should be made through them, so that they may be airy and accessible in all weathers. Where, as is often the case, the outer parts of a Pine wood look thin and scraggy, the variety in the Pine family is such that we may help and shelter the older 
wood. The Junipers, Mountain Pine, Yew, and close slow-growers like the Swiss Pine may be planted as a close-growing tree garland. In exposed places these may give good effect. The Holly, too, is the best of evergreens for underplanting and may be seen growing even in Beech woods. 


\section{CHAPTER $\mathrm{X}$}

\section{OF MIXED WOODS}

IN countries where forestry is best practised there is much evidence of the utility of having woods formed of trees of different kinds, ages, and times of cutting. The reasons are many, but perhaps the most serious are the following: When we plant a tree like the Larch, putting them in solid masses of the same age, any disease that comes to the tree is much more likely to sweep through the wood than it would be if trees of various kinds were intermixed. Wind, often a destroyer of trees, is far less severe in the mixed wood, not only because some of the kinds are wind-resisting, but also because the different ages and heights of the trees help to break its force. Mixed planting is more likely to lead to a better annual output, as the roots of mixed trees get more out of the ground than a wood of one kind of tree only. It also allows us to associate light-seeking trees, like the Pines, with others, like the Beech, that do well below them. It commits us to no monotonous or regular mixture, for it allows of varying the wood in a way that is good for it, either for effect or growth, and of adapting the tree to the soil. A boggy spot we may plant with Willows; a rocky knoll, with wind-resisting Beech; a wet stretch near a stream, with Spruce.

We may see in the forest-clad mountains of the Tyrol how often trees grow naturally together-Larch, Scotch Fir, and Norway Spruce. Where the conditions suit 
a given kind completely we see it prevail, but there are many other conditions in which several kinds of trees grow equally well-groups of Larch among colonies of Fir or Norway Spruce-also single trees of each kind scattered here and there with a sprinkling of Birch and Beech, until the ground rises so high that the trees of the Pine tribe clothe the rocks. Why should we not more often follow this way, by which vast and steep mountain ranges are clothed in some of the most picturesque forest regions of the world?

Mixed planting. Mixed planting is, in many conditions, the most profitable. It is the way, too, that best aids us to adapt the soil to the tree; all the more so in broken ground, or the many places where we find striking differences of soil in a small area. To take an example from a few acres of ground I have lately dealt with, we have a wet piece of ground near a stream, where there is a good chance for the Norway Spruce, which so often starves in dry soil, and above this wet ground there is a nearly level bed of stiff soil, which grows Oak of the best quality with a few Ash among it. Above the level Oak bed there are some acres of a shaly soil, on which the Oak starves; so the stunted Oaks are cleared, to plant with Larch and Scotch and Silver Fir; and these conditions occur in a wood of about twelve acres. It is not intended that any hard lines should be drawn between any of the trees, but that the kinds shall run into each other, as they so often do in natural forests where the soil or altitude changes.

In forming mixed woods the fine vigour of our native trees may often aid us by their persistent way of coming from seed where we least expect them. If, in a woodland district, we plant an arable field with Pines of 
various kinds, we shall often find vigorous Oak, Ash, and Birch seedlings keeping company with the young Pines which had the start of them by a few years. Mice, birds, and other natural agents carry the seed, and instead of cutting out the young and often healthy saplings, it is better to leave them to vary the wood.

Mixed planting by no means confines us to a fixed rule, but, on the contrary, enables us to take best advantage of the natural variations of soil and aspect. We might, in varied soils, enjoy the effect of one tree, passing gradually into mixed masses of evergreen and hardwood trees. The trees being of different ages and cut at different times, the wood would never at any time be shorn of its vigorous and constant forest growth. And this plan would be in no way against beautiful planting, as where it is in use there is not only good tree growth from ground valueless for any other purpose, but examples without end of tree grouping as an effective aid to landscape beauty.

But the good mixed planting is not the muddle mixture we too often see; the plan in no way absolves us from taking care that the trees used are those best fitted for the soil, climate, and elevation. It need not prevent us, where a sharp change of soil and degree of moisture takes place, from planting there only the kind of tree or trees that will thrive therein. 


\section{CHAPTER XI}

\section{FORMING WOODLAND RIDES}

Goop rides through woods are necessary for shooting, for the clearing of the woods, driving, hunting, and the pleasure of riding or walking in them, and they are often best dealt with in replanting worn-out underwoods. The older and more picturesque the woodland, the easier the task of making rides pleasant to the eye as well as right for use, though we see many woods without rides of any value. Native and other plants are often handsome in masses near rides, and their effect seen in any clear way in shade is as good as could be given by any plants. By these rides are among the right places to have beautiful native wood plants, such as Solomon's Seal, Lily of the Valley, and Willow Herb, and also many of our hardy Ferns, in moist spots, such as the Royal Fern. Groups of neglected native shrubs might also be planted here and there, and native trees such as the Aspen and Field Maple, not often planted in the usual mixtures. In warm and seashore districts not subject to severe frosts we may have groups of Pampas Grass, New Zealand Flax, and hardy Bamboo here and there, though generally it is better to trust to good native things even in such districts. If we go beyond these, let us take care that the shrubs are as hardy as any of our own; it is easy to find such among the hardy Azaleas and Rhododendrons and the beautiful Mountain Laurel (Kalmia), where the soil is not against us. 
Woodland rides should be not less than $\mathrm{I} 8$ feet wide, and it would be no loss from a shooting or other point of view to make them a few feet wider, and if a ditch be made on either side it ought to be in addition to the I8 feet. The surface should be Grass, Moss, dwarf Heather, Thymy turf, brown leaves, according to soil and elevation and other conditions. A reason for this is that such surfaces drink up and keep for their own use the rainfall, which if it fell on bare surfaces might turn our rides and paths into watercourses. In very hilly ground we may have to cut rides out of the hill-side, of shale or rough gravel, sand, or peat. In these conditions or on any surface where we cannot find a protecting carpet of vegetation of any kind we shall have to form little dicks aslant the walk to carry off the storm-water. Woodland drives should want no care beyond the annual 'fagging' which the gamekeepers do to remove Briers and all interloping rank growth before shooting begins. But in woods near the house, it may be worth while to rough mow the rides now and then.

Sunny spots in woods. Shade is one of the charms of the woods in summer; but where the shade is too great for any of our plants or bushes, we have our chance for sun-loving things in glades or open spaces, so often seen in natural forests. These are to be sought for the sake of various things-game, sun, light and shade, and the variety of tree form which is often seen around such openings. The floor of these glades may be of turf, Fern, Ivy, or any mixed plants of the woods, and they are also good places for evergreen or other covert, e.g. Savin, dwarf Mountain Pine, Partridge Berry, Heaths-either Cornish Heath or the more vigorous forms of Heather-and, if we can spare them, brilliant 
bushes like Azaleas. Bushes needing sun and warmth might be grouped in such spots, and in districts where the cold does not strike hard, as in a great length of the shore-lands of our islands, other exotics might be tried. But they should be chosen with care, and only for some distinct quality. The incidents of the wood itself will often offer the best places for our sunny spots, and there might be small openings, too, in shade, suggested often by wood-plants like Gerard's well-named Stubwort (Oxalis) and Primroses. As high trees take the place of underwood there is more need for woodland sunspots, and also for more open and airy rides, avoiding always the too common way of thinning so that each tree stands singly, a harmful though well-established British practice, and against all profit or other good from woodland.

We may by studying carefully the lines of easiest access and of grading in hilly districts, and the convenience of the varied labours or pleasures of the woodland, often gain a beautiful result. I have made many miles of such rides and no like labour has ever given me so good a return. Where the woodland is level the work consists of taking out old and often worn-out stubs. Where it is sloping it is more laborious, but even then not difficult. Where the woods have been neglected and are rather worn-out, it is often easy to get a good line where the ground is bare of trees and thus avoid felling timber. Sometimes we may take the ride under a great group of Oaks or Beech-trees to enjoy the beauty of their stems, and get a better effect than if we avoid them. In some cases the result was so striking that parts of the woods, before unnoticed, became picturesque even in the eyes of artists; the airy foreground and the 


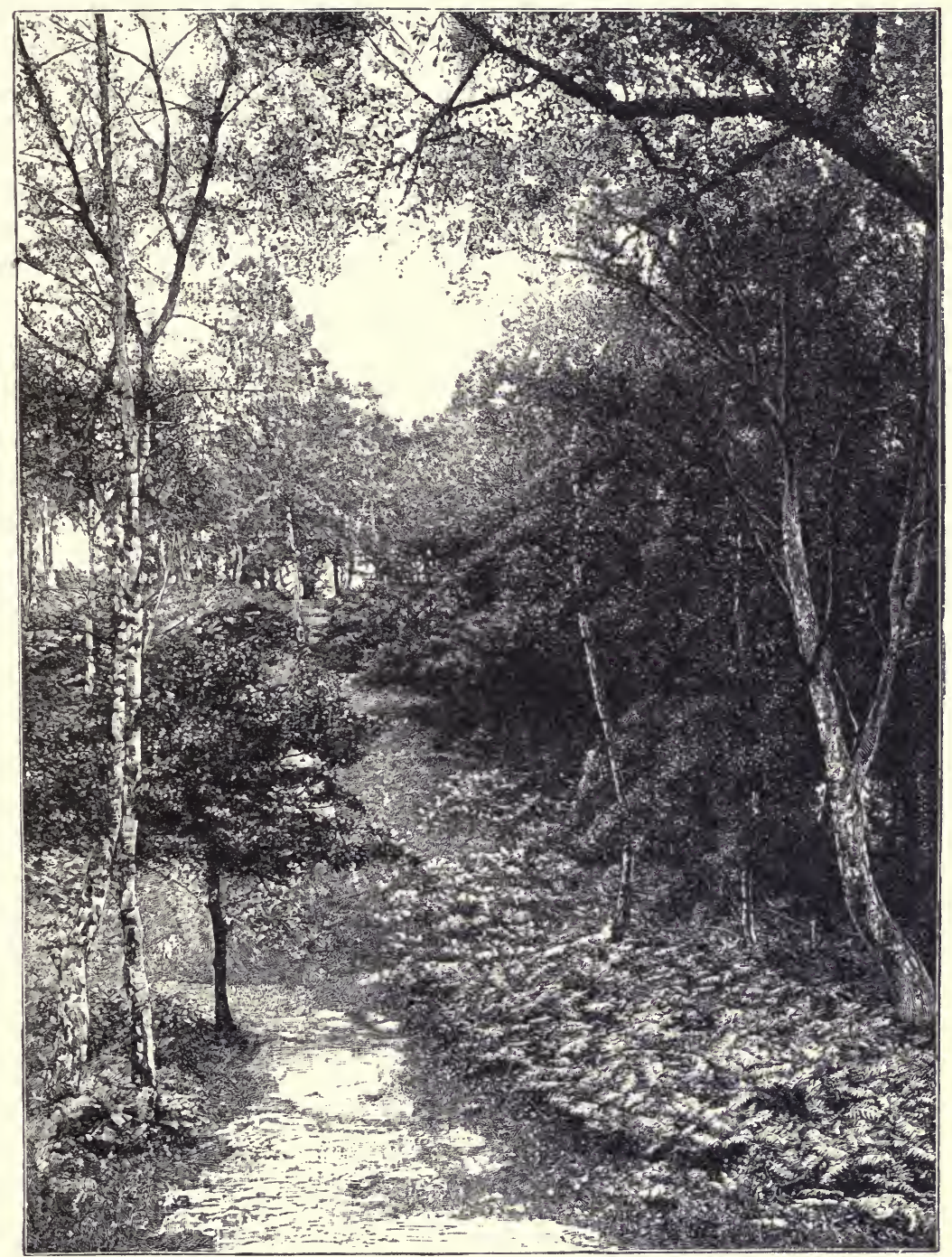

Woodland Ride 


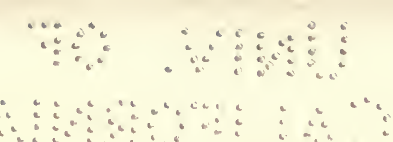


fine view along the clearances giving good pictures when the trees happen to come in the right way. Where there is much disturbance of the ground I sow mixed Grass seeds as soon as possible afterwards, mainly in April, but also in the summer and autumn. As to game, the airy rides are a distinct improvement in every way, creatures of all sorts getting a chance to air and sun themselves in the clearances. The gamekeepers like it much better, and the timber surveyor tells me that he always finds the best trees near the open rides.

Woodland shade. It is said by many who have lived under warmer skies than ours, that hot weather in Britain is more oppressive than in countries where the temperature is often much higher; and this is one reason why we should pay more attention to shaded rides and airy shade under trees. In a large area of country in the home counties many woodlands are wholly without airy and picturesque access, except for narrow rides closed up every year with Briers and underwood.

In past years, when underwood was valuable, people begrudged the space to form airy rides, but this reason no longer holds. Making such rides in no way lessens the value of the wood, because every inch of the ground is occupied by the roots of the near trees, and the best timber trees often grow near rides. If we can make rides beneath good old trees or groves all the better, as beneath such trees the undergrowth lessens, and the clearance is easier. By all such rides the lower boughs of the trees should be removed for the sake of showing the wood and stems; such branches are usually without value to the tree in its forest state. In the case of fine old trees, the tree itself is very often trying to get rid 
of its lower boughs, and yet we often see them impeding all progress about the lawns. Where there are good rides through old mixed or evergreen woods it is important not to let the undergrowth close in on each side, as it is very apt to do.

No clipping back. It is difficult to give an idea of the difference in the effect of such a ride when light and shade are let into it, and when, as is commonly the case, trees and undergrowth are clipped back to hard walls, good views, fine trees, and groups being all shut out. It is better not to clip in such cases, but always to work back to a good tree or group, and so get room for the air to move, the shade of the trees above being sufficient in each case. The pleasure of driving or walking is greater when one can see into the woods on each side and perhaps into the country beyond. 


\section{CHAPTER XII}

\section{WATER-SIDE PLANTING}

Even those who care for good planting are apt to neglect the water-side, and we see much land near it without any of the lovely effects which well-chosen river or lake-side trees give. Some things come of themselves, such as Osier and Withy, but they have little good effect. Often beautiful views are shut out by these weedy trees, and where the house is not in a commanding position they may do much harm. One of the most beautiful of situations for a house is upon a bluff near a river, as at Nuneham; and even where there is no bluff, as at Levens, the river may be a great aid in fine planting, and careful thought should be given to it.

The best water-side trees are often those of our own country and easily procured, fine in colour, and good in form. There are certainly gains in water-side position which we do not often find elsewhere; we get air and light, shade and breadth from the water itself, which prevents the dotting of plants over the whole area. Again, there is often good land beside rivers liable to flood, which we cannot plant with ordinary trees, and cannot wisely build upon, and these give us those rich levels that are such a gain in breadth to lowland landscape when fringed by noble planting. Flooding is in no way against the right trees upon islands, lake margins, and river-sides. Some of the best trees, like the Willows, are well used to floods, and even trees like the Eastern Plane, that we often associate with hot, 
dry soils, seem happy in ground sometimes flooded, as we may see in the Thames valley.

Of all sites for planting there are none in which we may have clearer guidance as to what is best than we have in islands and the margins of water, be it lake or river. The vegetation should be mostly of a spiry-leaved sort; Willows in many forms, often beautiful in colour both in summer and winter, with Dogwoods and Poplars. Even the Willows of Europe and Britain are ample to give fine effects, and some, like the White Willow, form tall timber trees. There is also a superb group of weeping trees among these Willows, some of them more precious than the Babylonian Willow. This is worth bearing in mind when seeking good and artistic effects. Take, for example, a piece of water, good in form of margin and right in every way in relation to the landscape ; it is quite easy to spoil the effect of it all by the use of trees which have not the form or colour characteristic of the water-side. By the right use of trees suited to the soil we may, on the other hand, make the scene beautiful in delicate colour and fine form-in a word, right at all seasons, whether as a picture, as covert, and even for timber.

The best trees for water-side planting are those of our own country, or of Europe and the northern world generally, though we need not refuse things that come to us from other countries. People are so much misled by showy descriptions in catalogues, and also by their own blindness to ugly things, that we often see misuse beside the water of variegated trees and shrubs like the variegated Elder, the Purple Beech, and other trees of the worst kind for such a place.

Tree Willows for effect. There are many Willows, 


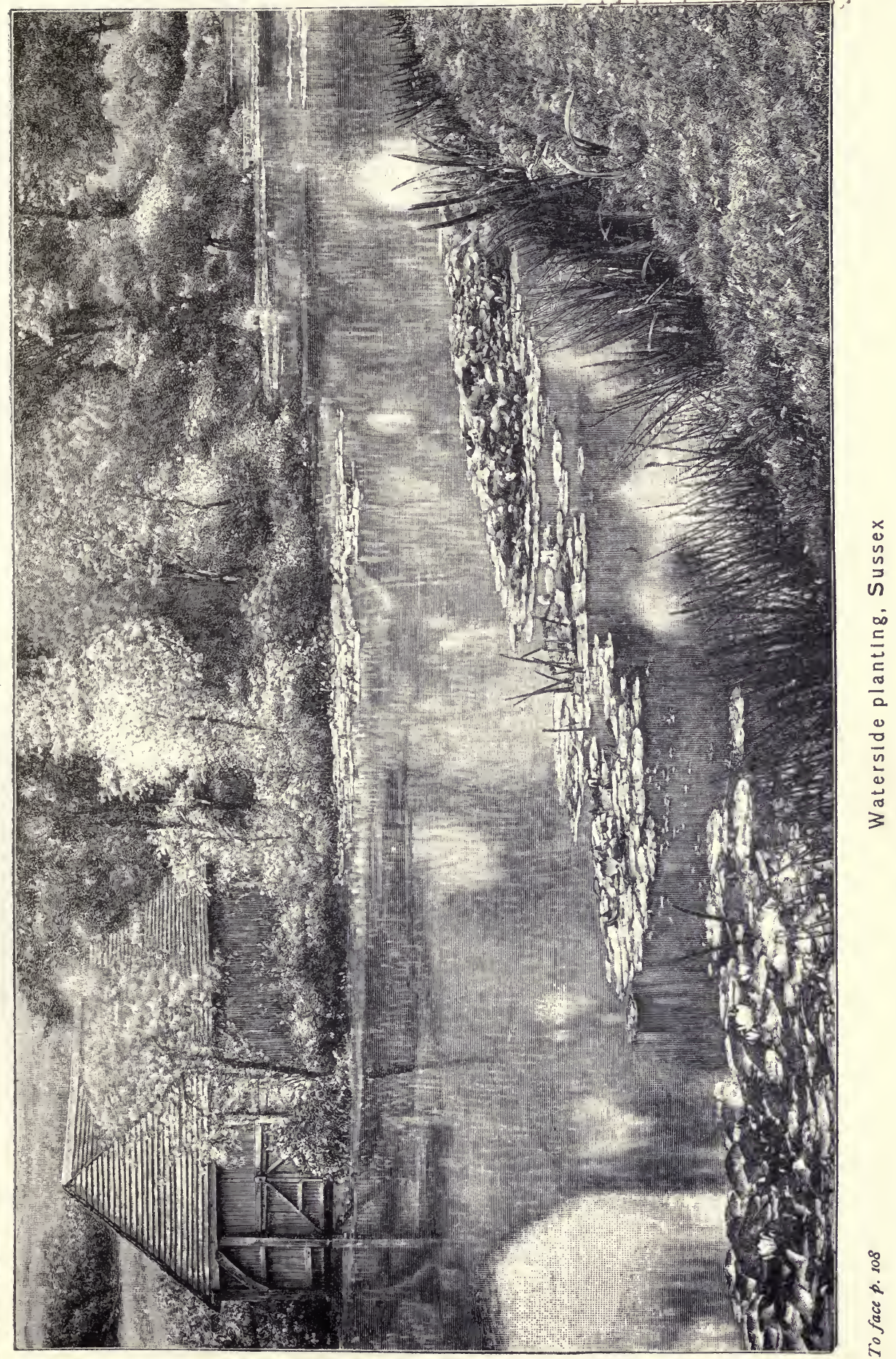


$\therefore$ 
but for good effect the best are the 'Tree Willows'those which may be had on their natural roots, and of some timber value. The best of these for our country is the White Willow, lovely at all times, but especially on days of storm, when other things are often at their worst. The best effect from planting I ever had was from putting a bundle of White Willows on an ugly bank across a lake; the effect obtained is excellent, and even the stiff bank is lost to view. The hybrids of the White Willow (Bedford Willow) are good also, and next best for colour is the Yellow Willow (Salix vitellina)classed by botanists as a variety of the White Willow, but for planters distinct in stature, form, and colour. It is often seen beside northern and Irish rivers, but, when massed in a marsh or bog, or beside a wide river, it is fine in effect and the best of all in wintry days. The Red Willow (Cardinal Willow) is a form of it, of even brighter colour. The Crack Willow (S. fragilis) is not so showy in colour, but is very picturesque in form upon river banks, and quite worthy of a place among the Tree Willows. The new weeping form of the Yellow Willow (S. vitellina pendula) is beautiful, but the desire to increase it quickly has led to grafting in nurseries, which means death, and ugliness in dying. To strike root as freely as a Willow is a proverb, yet men will graft Willows where the result is certain failure. There is not only the loss of a beautiful tree, but the stock upon which it is grafted-usually the Osier ( $S$. viminalis) - comes up instead, like a tree-weed, to obscure the view, and is difficult to get rid of. Many beautiful Willows of a rarer kind than the Tree Willows here named have been raised, but the few who plant lose them through grafting on the Osier. 
After Willows, the Poplars come in best in all northern countries. The White Poplar is beautiful in colour as a river-side tree, and superb in form when well grown. The supposed pyramidal variety of it is neither so good nor so lasting. The Poplars of the French rivers are also beautiful, though none are prettier than the Aspen. The Lombardy Poplar is sometimes very fine in valleys near water, but is apt to sicken. The Grey Poplar comes next to the White in beauty, and the Black Poplar is often grand beside water.

Some of the American marsh trees are very pretty near water, in particular the one called the Tupelo (Nyssa sylvatica), of which there is a fine tree at Strathfieldsaye, lovely in colour in autumn; but the summerleafing trees of the American woods have been much neglected since the vogue for planting conifers came in, so that we can point to but few examples of good results in our country. The Western Arbor-vitae and the Hemlock Spruce thrive in wet ground, as do the Norway Spruce and the Sitka Spruce. We resort to trees of the Pine tribe to clothe sandy or stony hills, but it is as well to know that for low and wet land we are not obliged to confine ourselves to Willows, Alders, and Poplars, if for any reason we prefer evergreen trees. In southern parts of Britain where (after its first youth is past) the Norway Spruce is often a failure, it will yet grow well beside streams and in wet bottoms. The Sitka Spruce-a valuable tree-is good also, and the Douglas Fir thrives in the hollows of wet woods. Even the Silver Fir, a tree that is not always happy in stiff soils, makes fine growth near water, and our native Yew is not averse to the water-side where dense evergreen covert is desired. The Red Cedar also grows well near 
water and gives dense cover, and, grouped among Dogwoods and Wild Guelder Rose, does not look amiss.

$A$ danger of water. The ugly pieces of artificial water, which so often disfigure country places, are often the cause of fatal accidents. These result chiefly from the stiff way in which the margins of such waters are made. Instead of the bank gradually sloping into the water, as is usual in natural lakes, it is frequently hipped in a steep way, leaving the water too deep at the margin. All artificial waters in any position where there is danger of children falling into them, should be made shallow and have a gradual slope from the margin. The bank of turf should fall gently to the water-never jump abruptly out of it-and the bottom should fall shallow from the margin. Art and safety go hand in hand in this way, for the abrupt margin is an eyesore to good effect, and wrong in every way for the plants that should grow on it, and is against the effects that should arise out of any happy union of shore and water. 


\section{CHAPTER XIII}

\section{SHORE-LANDS PLANTING}

WHEN we think of all the lovely things in our island gardens, from Caerhaes in Cornwall, to Castlewellan in the north of Ireland, why should we hesitate to plant near our wildest shores? Island planters should love the sea, as clearly some of them do, or we should never have such true gardens as Tregothnan, Abbotsbury, and many others along the shores of Cornwall and Devon. It is an error to suppose that these effects by the sea are only to be had in the south, because we have the striking instance of Lord Annesley's planting in the north of Ireland. Doubtless success is to a great extent a question of shelter, and one may often get that near the sea as well as anywhere else, in sheltered hollows near and behind hills lying against the prevailing winds. Certainly if we do nothing but leave the bare shorefields to the winds we do not get much beauty; but if care is taken in building up shelter through seashore shrubs and trees, then good planting may be done.

It is not the seashore folk and those who dwell by the many river valleys and estuaries that are to be pitied, but rather those struggling with inland and midland conditions. For those who have to face such winters as those of Hungary and central Germany there is no chance to walk in avenues of Palms, such as those of Mr. Fox at Falmouth, or among Tree-Ferns, Bananas, and Gum-trees, as at Menabilly; so that our privilege as island planters is a singular one in Europe, consider- 
ing our northern position. In no northern country can we see such a variety of exotic vegetation in the free air-Himalayan Rhododendron, Palm, Indian Magnolia. It would take a long time to free people's minds of the idea that it is only in the warm and often relaxing southern country that such beautiful results may be got; but we can see how wrong it is by such instances as those of Mr. Acton on the hills of Wicklow, and also the plantations at Bodorgan on the stormy coast of Anglesey. Given the same shelter and care in northern places beautiful results may also be had. Not only coast gardens may be beautiful, but also plantations of trees of the highest value, as, by working back from the shore, with storm-resisting shrubs and trees, we soon get, even in level and exposed shores, the shelter which gives us a warm, protecting, evergreen wood. Few countries are so rich in sheltering trees as our own, owing to the evergreens that thrive in seashore districts. Shelter may be near, distant for wind-breaks, across the line of prevailing winds, and may be of Yew, Holly, Cedar of Lebanon, native Fir, the Ilex, and Austrian and Corsican Pines.

By the use near the sea of small-leaved bushes like the Tamarisks, Sea Buckthorn, Baccharis, and small Willows, we very soon get some shelter, and by backing these with close-growing conifers like our Juniper and some of the sea-loving Pines like Pinaster, and the Monterey Cypress and the Monterey Pine, we get shelter for trees, and Ioo yards from the shore we may walk in warm woods. Having got our shelter, the growth of the hardy Pines of the northern world seems as easy by the sea as anywhere ; indeed, if there is any one place where the rather tender Pines are grown well 
it is near the sea in places around our coast, where, if the soil is good, one has not to be so careful about the hardiness of trees we select as one has to be in inland places.

The Evergreen Qak is the most precious of evergreen trees near the sea; but as it is not very easily transplanted from nursery-bought plants, it is just as well to raise it at home and plant it young. Seed may be dibbled in where we wish it to grow. This Evergreen Oak withstands gales better than any other tree, and is precious for the south and west and all seashore districts. It suffers from indiscriminate planting with other and sometimes coarser things, and is rarely grouped in an effective way, although at Ham House, Killerton, St. Ann's, Tregothnan, and Holkham, we may see the good effect of grouping it. There are many fine trees of it in coast districts in England and Ireland. Where there is room the tree should be grouped or massed, as, apart from effect, we get the best shelter in that way. At Abbotsbury it is put for an evergreen shelter round every new plantation, even in that sheltered dell by the sea.

Among the taller Pines for seashore woods the best is the Corsican, and, both from the climate of its islandhome on the mountains, and the result of trials in various parts of England and Ireland, we may make up our minds about it. The Pines of the northern Pacific coast, too, are well used to sea influences, and hence we see in our country good results from planting them near the sea, as, for example, Menzies' Spruce at Hunstanton, the Monterey Pine at Bicton, and the Redwood in many places near the sea. One good result of planting in such places is that we may use so many evergreen trees, 
from the Holly to the Cedar, and so get a certain amount of warmth as well as shelter. Sometimes physical obstacles help in shore planting, as dunes and low hills, in the shelter of which we make a beginning. Of this there is an instructive example at Holkham in the long Pine wood flanking that cold and often angry shore. And if we succeed in planting a beautiful evergreen wood within a few yards of the sea we can then work back landwards as far as we care to go. In starting, however, near the shore it is best to use the Corsican, Austrian, and Monterey Pines, and the Holly Oak, leaving the broad-leaved trees until we get full protection.

There is nowhere a more wind-beaten shore than that of Anglesea, judging by the appearance of the few stunted native trees in the open land, but planting of an effective kind has been done almost on the seashore. At the water's edge is the Sea Buckthorn, Furze, and Barberry, which first bar the south-western gales and winds; a few paces within these, Pines and Evergreen Oaks appear, and soon, with the aid of these excellent shore trees, almost any kind of evergreen planting may be carried out. The contrast between the wind-swept surface of the island and the noble avenue of evergreen trees leading to the house is very striking. Such planting, however, can be carried out best where we plant a wood and not a mere belt.

On the vast Danish heaths and dunes of Jutland, which are constantly swept by the gales from the North Sea, the White Spruce (Picea alba) has for a long time been extensively planted and used as the main element of shelter round numerous large and small plantations. It answers these purposes so well, that no other known species would be able to replace it in Danish planting. 


\section{CHAPTER XIV}

MOUNTAIN AND HILL AND DOWN PLANTING

THE tree is the crown and garland of the mountain, and in our land of mostly gentle hills there need be no fear of planting too many, the hills of Wales and Ireland, north England, and the down country being as bare of trees as desert lands. As to this question of hill and mountain planting there are many things to encourage us. Far beyond the golden plains of Germany in harvest days, we see the endless hills close set with Pinesa lovely background to the rich plains. Though these vast hill woods are planted by man for use, in no natural forest is the effect on the landscape better. That should settle any question as to the effects of woods of nature's planting and of man's. In that greatest of tree countries, North West America, it is only when we get above the plains of wheat and vine that our astonished eyes see in all their dignity the colossal Pines of the mountain. In crossing the ocean of shaly hills of North Africa we never see a tree until we climb far up into the mountain where the snow lies until May, and then the plumy branches of the Cedar are seen with the wild flowers and thorns of our own land at their feet.

There are mountain heights on which all vegetation ceases, but in our country these seldom occur ; and most of our mountain land might be planted, and there is a vast area of it both in Ireland, Wales, and England.

Here the main thing would be to choose carefully 
trees that fear no wind or cold. We should plant small and close, and occasionally even sow the seed direct in the sod. In the vast ranges of well-planted mountain land in Europe we have clear guidance as to what to plant. The trees that clothe the sharp mountain slopes for hundreds of miles in the Tyrol will not fail us here, except the Spruce in the dry country of eastern and southern England. After the Pines of Europe some of the American trees are good mountain trees, especially those of the east side and the Rocky Mountain Spruce. One European tree not common with us, but which well deserves to be, is the Swiss Pine (P. Cembra), which is most precious for mountain planting. In our country it thrives in any soil, and being a native of Siberia and the coldest parts of the Swiss mountains it is just the tree for the bleakest hills of Wales. The Cedars of Lebanon and Atlas deserve a good place as forest and mountain trees, being true mountaineers and accustomed to poor soil. In every hill and mountain country there are ravines and hollows and small valleys or coombs in which the soil is better, and that is where we should plant our Cedars. If we use broad-leaved trees the best of all is the Sycamore Maple, a tree that endures sea and mountain winds and storms perhaps better than any other summer-leafing tree. If we plant Oak on the flanks of fertile hills, it should be the Durmast Oak. In the Alps we often see the Beech climbing the hills, with the Silver Fir and Spruce, and therefore it would help us especially in the limestone hills of Ireland and the chalk regions of England.

High moorland planting. In a paper read by Sir John Stirling-Maxwell, he states that two conditions appear essential to the creation of new forests in the Highlands, 


\section{8 Mountain and hill and down planting}

one a rise in the price of timber, and the other some measure of assistance from the State, certainly in the way of instruction and experiment, and possibly also in the way of loans. He says:

' My experiments in this line have been carried on since I892 on moorlands in the upper basin of the river Spean, varying in altitude from $I, 250$ to $I, 500$ feet. The tract of which they form part is used as a deer forest, being fit for nothing else. Between 500 and 600 acres have been enclosed for planting without in any way diminishing the value of the deer forest, as none of the good grazing ground has been included.

' The results of draining and planting in the ordinary Scotch fashion have been disappointing. The heavy rainfall and the retentive character of the peat render draining useless unless the drains are very close together. The matted texture of living peat, which the roots of young plants are very slow to pierce, seems also to exaggerate the inherent evils of notching. The roots tend to develop in the plane on the notch, and if they have been twisted in planting, the root-system has no chance of righting itself, and becomes hopelessly deformed.

'A trial is now being made of the system recently perfected in Belgium to meet the same difficulties. The moors on the frontiers of Belgium and Germany very closely resemble ours in soil and climate, and in the plants which cover them. The Belgian Government is now planting so much of these moors as is public property up to a level of about 2,000 feet, and private owners are following its example. It was found that plants notched into peat at this altitude made no progress at all for five or six years. That delay is now avoided by setting every plant in the centre of a large turf turned upside down. The ground has to be drained in any case, and numerous shallow drains are found to succeed best. These are carefully calculated to supply the number of turfs required. The Belgian Government plants very wide, usually at 6 feet both ways,-its object being to convert a vast extent of moor- 


\section{Mountain and hill and down planting}

land into forest as soon as possible. The Government foresters themselves consider this distance too wide, and I observed that the plantations on an adjoining property were being made at about 4 feet. Let us take this example as better suited to Scotland. To plant at about 4 feet, drains will be required every 12 feet, with three rows of plants between. If they are made 2 feet wide at the top, tapering to 15 inches at the bottom, and ro inches deep, and the turfs are cut every 20 inches, the drain will yield exactly the number and size of turfs required. As the drain is formed, the first, second, and third turfs are thrown alternately to left and right, always face downwards.

'The turfs are left for a year. By that time the ground has begun to dry, the turfs have sunk considerably, and the herbage below them has begun to decay. They are not good subjects for notching, as the notches would be apt to gape in dry weather. But they are very good subjects for what may be called miniature pit-planting. A heap is made of the best soil or gravel available near the spot, and this, if pure, is mixed with basic slag, about half an ounce of slag to the cubic foot of soil. The planter cuts a circular plug from the centre of each turf with a long-handled planting tool, leaving a hole deep enough to allow the roots of the young plant to be spread out to their full depth. In this hole the tree is planted with two small handfuls of the prepared soil, while the plug is broken up to fill in the top.

'Trees planted in this fashion seem to suffer little more interruption in their growth than would be occasioned by a move from one part of the nursery to another. The extra expense is partly made up by the use of smaller plants, which soon outgrow larger plants which have been notched into natural surfaces five or six years earlier. On the Belgian moors, where they plant little except Spruce, these are usually four years old (two years in the seed-bed, and two years trans. planted). But Scots Pine, two years old, would be quite suitable for the purpose, and could be taken straight from the nursery if they had not been sown too thick.'-Transactions Scottish Arboricultural Society. 


\section{I20 Mountain and hill and down planting}

In the hard rocky hill or mountain we are not liable to landslips.

Trees on ground liable to landslips. In some soils landslips are far from uncommon, and in such a country it is best to be careful to keep surfaces likely to be affected in that way planted, so far as may be. Slopes on such ground cleared of trees, and which for ages may have held sound, sometimes slip after the roots of the trees begin to decay. Roads and drives, too, are apt to give trouble if made near such ground. If near a house or road a landslip may lead to great expense. Unplanted land with the same tendency should be planted at the earliest opportunity with Oak, Beech, and Tree Willows, with Larch between them, and as these trees got old and strong they would hold the bank. I once cut down some old Oaks which grew on a slope above a road, one of those roads that have been there for ages, and, like so many in the southern country, is cut deep into the earth. Soon after the Oaks were cleared and the stout roots which held the bank together had lost their hold, the great bank began to slip down to the road. The cost and labour to repair the bank I should prefer not to tell of. Difficulties of this sort do not often arise except in diversified country.

Down planting. In England there are vast areas of beautiful down land with a divine air and lovely forms of hill and dale, but bare of trees as a desert without an oasis. Nature does little or nothing here for the tree-the thin, dry, chalk-hill soil, the slight rainfall, help to make the desolation, while in view of the hills Oak and Ash are strong and numerous in the Weald.

Now here, happily, trees not natives of our land may give us great aid in imparting a crowning grace to these 


\section{Mountain and hill and down planting I I}

sunny hills. Planting down country is one of the most interesting questions a planter can face.

In ordinary soils the haphazard planting one sees everywhere may take well, though the final result may be anything but what we seek in forestry. The same kind of planting on the downs must fail. In down planting the trees must be those that put up with the conditions; and here foreign trees come to our aid. One such tree alone is a great gain for the down, and that is the Austrian Pine, which in its wild state inhabits a very chalky tract of country in Lower Austria. In our country it is a precious tree for such situations and might be planted alternately with Larch. It is a great soilmaker and would improve the soil of much of the down country. I would also trust the Corsican Pine, but on the best ground, and the Cedars of Lebanon and Atlas might also have a place with trees that can grow in calcareous soil. They are certainly worthy of a trial planted young and treated as forest trees.

While the colossal trees of the Pacific coast are those that love and must have a sandy loam and fertile soil to thrive in, other Pines, like the ones previously mentioned, will thrive on chalky soils. Most notable of all, perhaps, is our native Yew, the plumes of which we see on many a Kentish down, often struggling with most adverse conditions and making excellent covert and shelter.

The Numidian Fir tolerates a chalky soil and is a hardier tree than the Crimean Fir. The White Oriental Spruce is a graceful tree that will succeed well, and I think also the Rocky Mountain Spruce (P. Parryana). With the Corsican and Austrian Pines might also be tried the Pyrenean and the Calabrian. The beautiful 


\section{Mountain and hill and doren planting}

Abies cephalonica and cilicica are also said to tolerate chalk.

The ever-precious Larch comes in to help us in down planting, alternately with other evergreen trees, and, given the coolest soils, it will help for a time even if it is to be eventually cut away.

The Beech is the great forest tree of the down country, and we have many instances of its profitable culture both in England and northern France. So that we have more trees than one would at first expect for this difficult planting. It is not only necessary to get the right trees and plant them young, but also to include in our planting every bit of covert, native or otherwise, that grows in or will grow on the chalk. First among these we may name the native Juniper. An excellent covert plant and a native also of the southern downs is the common Box, the most graceful of covert trees for open and sunny places. The plumy Savin, also, of the Alps of Europe would help, and Furze or any bushy thing that will live on the ground, the object being to create a covert and keep the soil cool. In the little valleys or the richer soils about the house the Walnut is a precious tree.

In endeavouring to establish covert in a down country, the seed might be sown in free bare ground of things like Box and Furze, even without any preparation of the soil or covering. But these plants are offered by the thousands in forest nurseries. Where the down turf is much matted together it may be well to follow the plan adopted in the Belgian experiments before referred to or a modification of it, say by turning a few turfs upside down around each plant. This should be done after the planting, and may be done at a later period-in spring for choice. 


\section{CHAPTER XV}

WOODLAND FINE IN COLOUR

Nothing I may say can sufficiently show the high importance of this to the planter. The first thing to do is to get the splashy, ugly variegation of the nursery out of our way. The invention of variegated conifers and other variegated trees and shrubs has been the misfortune of those who see true natural colour. All that artificial and hideous colour which often disfigures even noble gardens should be avoided altogether by the woodland planter. Remember that in addition to the beauty of our common trees-Ash, Beech, and Oaksome of our less planted native trees-Wild Servicetree, the Aspen, Wild Cherry, Rowan, Bird Cherry, Hornbeam, White Beam-are often good in colour.

Apart from its beauty, a great charm is that this lovely woodland colour comes just when all our garden things are laid low. Good as the colour of our native trees is, we ought not to forget the beauty of the trees of North America and Asia, and the importance of planting these where they are free and hardy in our country. Our woods are often full of colour right through the autumn, and some of the American trees, where people have the art of grouping them effectively, have as fine a colour in our woods as in their own. To the eye open to the delicate gradation and variety of good colour, that of our British woods is as good as any, and the winter effects are often most beautiful, from Alders by the busy 
stream to Oaks massed with silvered stems. Almost every native tree and shrub is beautiful in colour of flower, leaf, or fruit. Scarlet Dogwood, Red and Yellow Willows, Gorse, Broom, Holly in berry, Rowan, our native Barberry (a lovely thing in fruit in groups), the Spindle-tree, and the Wild Guelder Rose, are among our trees that give the most brilliant effect; but for refined colour that of our common woodland trees in picturesque planting is best of all.

Although we are mainly concerned here with the trees that give us fine colour, yet undergrowth is always with us, and our own native things-Bracken, Briers, and Wild Roses-are often very good in colour. It is easy to add to these, if we care to, the number of Wild Roses in cultivation now being so large. Dogwoods help very much as undergrowth, as also do Viburnum and Hazel. Although we are chiefly considering the colour of foliage, we cannot put out of view the good colour of some shrubs, such as Box, Furze, and Broom, and for poor places and bare, poor soils we have our native Heaths, which give as good a ground colour as any plants can give.

Oaks. The most beautiful colour of our native Oak is in the time of bud and early leaf, when a wood of Oaks is so striking for its charm and variety, especially if from a near height. In autumn, Oak also takes fine colour, and next we have the colour of the stems in winter. The American Oaks, so little grown with us in woodland, are unrivalled for depth of hue. What can be more effective in autumn than Quercus tinctoria? The Red Oak, too, has its charms in the reddish tint of the decaying leaves. Two others are nearly equally good - the American White Oak and the Chestnut-leaved Oak. 
Maples. Some of these are splendid in colour, the best for Britain being the Norway Maple, which has given me a finer result as regards colour than any other tree. The American Maples are brilliant, too, though generally not quite so vigorous in our country. The smaller Japanese Maples are also often rich in colour, but in woodland work we must always prefer the greater trees. The Silver-leaf Maple (Acer dasycarpum) is one of the most graceful of trees ; in early spring it is covered with myriads of reddish flowers; then its leaves, green above, silvery-white below, turn in autumn to a varied colour. The Scarlet Maple is brilliant in colour, and in spring bears its deep red blossoms. The Sugar Maple (Acer saccharinum) is one of the brightest of American trees, and is much valued, both for its wood and for the beauty of its form and foliage, but it is not so free in our country. The purple-leaved forms of the Sycamore, and also of the Norway Maple, are worth having, but only when they may be raised from seed. If we had but the Tree Maples alone, and excluding every golden variety or variegation, we could make our woodland into a noble picture of fine colour in autumn.

Willows. Taking them all the year round, I know nothing quite so refined in colour as the Tree Willows, and all the better if grouped-by streams, in moist woods, and in rich bottom soil. They differ each month in effect, and are always good in colour, even when bare of leaves. The best is the White Willow (Salix alba), which grows into a forest tree; the Red and the Yellow Willows, by botanists supposed to be forms of the White Willow, are distinct from it for woodland planting; all give good colour and are easily raised. I should like to see these Tree Willows grown from seed, if possible, as 
all cuttings are against us for the woodland; but the facility of increase from cuttings is so easy that it is difficult to get them otherwise.

Poplars. The Poplars of Europe and North America give us clouds of soft colour in the autumn, and are also beautiful in the budding and early-leafing stages. The White and Grey Poplars of Europe are distinct in colour. Some of the kinds are little planted yet, such as $P$. trichocarpa, which also gives fine colour at different seasons, as do the American Poplars, the Black Poplar, and our nativ Aspen.

Ash. Among the summer-leafing trees few are finer than the American and other exotic kinds of Ash, of which the high value may be well suggested to us by the qualities of our own. The leaves of many are fine in form, and they take a good colour; but when tried so far in our land they are usually from over-transplanted or worked plants in nurseries. As woodland trees they deserve to be raised from seed, and sown, if possible, where they are to grow. Among those that might be tried are lentiscifolia, Oregona, Mariesi, pennsylvanica, and rhyncophylla.

Beech. The greatest mass of fine woodland colour in our own islands from Scotland southwards we have from the Beech. The tree has produced varieties popular in gardens, such as the dark-leaved forms, which we must guard against overdoing, avoiding them wholly where increased by grafting or any other mode save the natural one. Some of these dark-leaved forms come from seed, and in that case are worth planting for variety sake.

Tupelo-tree (Nyssa). These trees, which attain to considerable size in North America, take on a fine colour in our country, even away from the swamps and wet 
land in which they thrive at home, and their effect is often beautiful. There are several kinds, all thriving in swampy soil and wet bottoms.

Thorns (Crataegus). One of the most charming bits of planting I ever did for colour was making field fences of the Cockspur Thorn, which is not only that rare thing, a good fence plant, but is very fine in colour; in autumn a rich brown, or, in a sunny autumn, red. When such plants were sold by nurserymen singly they were often grafted, and, therefore, useless. There have lately been many Thorns found in America, some of which will certainly be excellent for colour. In a collection of the newer. Thorns I have from the Arnold Arboretum at Boston, nearly every kind showed good colour in early November, 1906, though some are quite small as yet.

Sumachs (Rhus). These, although by no means so much talked of as the Oaks, and neglected, are brilliant in colour, and easily grown in any poor soils. The Venetian Sumach is familiar in gardens, and with its purple form is good in colour. The sturdy-growing species with long pinnate leaves, such as the Stag'shorn Sumach (R. typhina) from North America, with Rhus Osbecki and R. succedanea from China and Japan, vie with the simple-leaved bush forms and $R$. cotinoides in their vivid hues, while the brightest among them are rivalled by the curious climbing Poison Ivy, which in American woods clothes the stems of lofty trees. $R$. glabra is brilliant in colour in autumn.

Birches. The beauty of our European Birch, marked as it is, need not shut our eyes to the good colour of the American Birches, which show so well in our country, the Canoe Birch and the Paper Birch giving good colour with us. One other species is conspicuous 
in the woods in winter, the Yellow Birch (B. lutea) having its trunk covered with loose flakes of silvery bark. The stems of Birches are often beautiful in colour after the leaves have fallen, the fine effect of this being best seen where the trees are massed in groves.

The Ginkgo-tree. This lovely tree, as yet not much planted as a woodland tree, is very beautiful in colour in autumn, and, indeed, at all times. Though slow to start, there is no reason why it should not be grown in sheltered parts of woods in good soil, and as often as may be in alluvial bottoms.

Buckeye or Horse Chestnut. These have much beauty of foliage in autumn, although, except in the case of the common kind, we seldom enjoy it. I remember in California being much struck with the colour of the Californian kind, which growing in groups on sandy soils gave one the effect of rocks, owing to their whitened foliage.

Alder. Often trees which do not strike us by their showy colour in autumn may have much refined beauty of colour, as in the case of the Common Alder in the early part of the year, the effect being always better where the trees are massed in natural or picturesque ways; and other Alders are worth a place too.

Vines (Vitis). Although Vines are not forest trees they may be very well associated with them, especially the greater Vines, such as Coignetiae and Thunbergi, which will grow to 40 or 50 feet high on trees, and give superb effects. There are also new Vines from China and Japan, which will help us very much in this way. What used to be called the Virginian Creepers are now united with the Vines, and are also getting richer in kinds. Running up trees, they produce a fine effect 
without much injury to the tree. They are so easily propagated, that one could easily indulge in a little experiment with them on tall trees. If we grow the bolder and finer Vines we may enjoy colour pictures better than any garden can give, just when gardens fade away before autumnal storms.

Guelder Rose. There is nothing prettier, either in flower, fruit, or leaf, than the common Viburnum of our woods, which is not always to be found in nurseries, but is very easily raised. It is a brilliant shrub for undergrowth, especially by streams and in moist places. It belongs to a great family of shrubs, many of which are fine in colour of leaf, but not usually plentiful enough for extensive planting.

Dogwoods. These are of high value as undergrowth. The white-fruited Siberian Dogwood is the most conspicuous as well as the most generally grown. The deep colour of its branches, which becomes richer as spring approaches, gives a brilliant effect at any time. Next to the Siberian species Cormus stolonifera possesses bright colour in a high degree, and the branches of the Silky Cornel (C. sericea) have a more or less purplish hue. Azaleas. These give lovely colour in almost any situation, and where we have them plentiful to plant as undergrowth, as at Dropmore, they are charming in colour of flower and leaf too.

Snowy Mespilus. This early-blooming American tree, very hardy and free in our country, has fine colour charm in autumn. It is common in nurseries. Others of the genus are also good, but not so easily got in quantity, and the same may be said of nearly all related trees, as the Medlar and Pear.

Parrottia. This Persian tree is little planted in our K 
country yet, but it is splendid in colour, even in poor, stiff soils.

Spindle-tree. Our native Spindle-tree (Euonymus europaeus) and the south European $E$. latifolius are brilliant, and so is $E$. Thunbergianus.

The Sweet Gum (Liquidambar styraciflua), whose leaves are usually of a deep purplish red, lit up more or less with orange, is one of the brightest coloured of all our trees in autumn.

Tulip-tree (Liriodendron tulipiferum). This, one of the most beautiful of North American trees, is often suffused with a rich golden glow, a fine tree making quite a feature in the landscape.

Limes. The Limes are often pleasant in colour, but they are a neglected race. The Tree Limes should be more thought of, particularly the American Lime, or Basswood, and, better still, the Silver Lime of eastern Europe.

Hickories, Walnuts, and Winged Walnuts. The Hickories are often very soft and fine in colour; but they are neglected in our country, as are the Walnuts and the elegant Winged Walnuts (Pterocarya), these all thriving in open, warm soils.

Larches. The European Larch is one of the most precious trees ever introduced to our islands, and is beautiful in colour, one may say, throughout the year, though most showy in November. The Japanese Larch, a little different in hue, is quite as good. There are other great Larches we hear of, but unfortunately they are not plentiful enough for woodland work. 


\section{CHAPER XVI}

\section{AVOIDABLE WASTE IN PLANTING}

Everything which tends to simplify planting is a gain, and much of the work given to it is needless and wasteful, particularly trenching and draining - two costly labours. I live in a cool country with a wet soil, and never drain for any kind of planting in woods, but adapt the trees to the soil, which is the true way. There are trees, American and European, that will almost stand in water and be none the worse for it.

Another costly and needless labour is trenching. I have young woods of Pine planted in poor fields not of very good soil, and people say they have never seen woods more vigorous for their age, yet the ground was neither trenched nor dug for them. The poor hill-lands that are now recognized as worth planting seldom need draining, as they are often naturally drained. One of the pleas for planting such lands is that it arrests denudation and conserves the moisture and fertility of the soil. And even where the soil is too wet much can be done to drain it by a good choice of kinds-Poplars, Willows, and Spruce are good drainers.

Draining. In certain cases, owing to a uniform lowness of surface, draining may be needed, but in much forest work it is not. Light sandy soils and hill soils seldom need draining, except when they lie upon a hard pan, such as is here and there found in peaty districts, 
and where the water stands however light the rainfall may be. Where the surface soil in such cases is not deep, and an outfall can be found-not an easy matter on level tracts-the surface water can be led off by open drains, but when the peat is deep the water will not subside below the drain levels.

Some of the best German foresters hold that in many soils the best system is that of having trees of different ages, different kinds, and different times of cutting, and of planting the trees according to soil and situation. It is certainly a better way than the level mixture of trees which has to adapt itself to all conditions. The massing way also leads to beauty, as by its means we keep and accentuate any varied incidents of the surface. Planting Austrian Pine, Larch, Scotch Fir, and Beech on the drier ground, Spruce, Sitka Spruce, and Douglas Fir in the sheltered and moist hollows, Oak, Ash, Sycamore, and Elm on the cool ground, and Poplar, Willow, and Alder wherever the soil is deep and moist, is a better plan than the mixing together on the same soil of kinds no two of which are alike in their wants.

Trenching. Trenching does not add to the staple of poor soils such as are generally planted with forest trees, useful though it may be in rich garden ground where a rank, quick growth is sought. Even if we can face the great cost of trenching, the labour is not always to be had. I have seen a country-side denuded of labourers in order to trench ground for planting, and the result no better than could have been got by a plough run through the land, or even if the trees had been planted in the sod. One of the best things about a wood is that it finds its own soil, and if we plant closely and well, and choose the right trees, it very soon 
begins to do this, as many of the finest natural woods have done for ages. Woods planted a dozen years will be found to have a good deposit of leaf-soil-this is in cases where the tree suits the ground and where the young trees are thick enough. In the open, common loose way of planting we may look in vain for any such deposit, as the Grass absorbs it all. The effect of a heavy fall of leaf-soil from the lower branches of Pine and other trees is that, in hot and dry seasons, when farmers and gardeners are at their wits' end to get water, the wood is cool and safe.

Trees as soil-makers. To the pleasure-ground planter these ideas will seem folly; he considers all such costly work as drainage and trenching essential to the success of his shrubbery. From his point of view, which is to get a rapid growth in the rampant growers that he usually plants, this may be desirable; but where is the shrubbery that can show as good a growth as many a woodland or forest? It does not exist. Trees will often grow well in abandoned scoriae, mine-rubbish, and other ugly earth surfaces. But the planter of such surfaces must look a little to kinds and their habits as well as to soil. In the planting of lands of no 'quality' or poor situation the kind of tree is important, as each has its preferences, and though many hardy trees will grow in almost any situation, it by no means follows that we get good timber from them. Oak, Ash, and nearly every hard-wood tree will grow almost anywhere, but not always be worth cutting. Oak is much affected by the quality of the land, and, even where it grows rapidly and large, is often not as good timber as that of smaller trees. Spruce on a wet western hillside will make growth such as we never see in southern 
Britain, and our quick-grown Scotch Fir is never so valuable for timber as the same tree of the mountains of western Europe. Rainfall too has much effect on trees, and also elevated situations; in such we might venture to plant trees which would be started too early by the milder climate of the south. In the wood we need no manure cart, and in the hottest years the trees maintain their freshness. Vast areas of European mountains are covered with Pines, although there is scarcely a trace of soil over the ribs of the mountain. Those who are now seeking to plant with a garland of trees the hideous refuse-heaps of the Black Country are right in their efforts; however poor the land may be when the trees are first planted, the annual layer of fallen leaves soon forms a deposit of mould, between which and the natural soil the roots of the trees are always found in great numbers. The older the wood the deeper the leaf-soil : in old Beech and other forests it is extraordinary to what an extent this leaf-mould has accumulated. If it were not for it, generation after generation of the same tree could not have succeeded each other on the same ground. Mountains which unplanted would have been almost bared to the rock by constant denudation, have a good soil of leaf-mould ; the same may be said of Fir and Spruce woods, in which the fallen Pine-needles have formed a bed of black mould. Tree crops manure themselves and enrich the ground on which they grow, a fact that should never be lost sight of in considering the planting of poor lands. Many do not plant, fearing the cost of labour and plants, and all would do well to consider the wastefulness of planting as usually done and the heavy labours undergone for no lasting gain. 
By raising from seed where the trees are to grow, by the use of young plants only, by avoiding trenching and digging, by close planting at first, by keeping rabbits and hares out of the 'young planting' for at least seven years, and by thought as to the nature of the soil in relation to the trees we plant on it, the bugbear of needless cost may be laid low.

$B$ ready. Any spirited planter will care to dwell least on the losses he has had through delays in planting after the plants come owing to the ground not being ready. However young and fit the trees, they suffer if kept too long in the little bundles in which they are sent, nor do they improve by being put in stock. The older the trees the more the danger. Delays through frost we cannot avoid, but in various other ways we can guard against loss. The right way is to prepare the ground beforehand in the spring, summer, or early autumn; and if wiring or other defence against ground game is needed, let that also be done and the piece of ground to be planted settled and ready. If in fallow throughout the summer previous to planting that would be an advantage. Then when the plants come to hand they are taken direct to the place and put in at once. In this way many failures can be avoided. Choose or order the plants early in the autumn, but do not let them be sent from a distance before the leaves have fallen, as it sometimes causes them to heat on the way. Where, as in my case, we attempt to convert underwood into high wood, the only way out of it I know is to plant good strong saplings-say 6 to 8 feet-but in getting these from a distance, which we often have to do, it is well to get them from nurseries where we know they are transplanted, and above all not too old or 
'staggy', especially in the case of Oaks, or we are certain to lose many of them.

The greatest loss in planting is perhaps in the ordering of ordinary trees, which most people plant 2 feet or 3 feet high. If there is any difficulty in transit, resulting in the roots getting too dry, \&c., or delays through frost, \&c., you may put it down that the losses will be three times as great as in the case of young and right-sized trees for planting in new ground. These should never exceed two or three years old. 


\section{CHAPTER XVII}

\section{THE WOODLAND GARDEN}

In several country places I have lately seen woods of singular tree beauty - woods with all the natural advantages of soil, air, and country, and well placed near the house-a charm which does not always occur. There was all the dignity and grace of trees planted with loving care by past owners; but such woodland is very often neglected until ugly plants such as Nettles, Dog's Mercury, and, most hateful of all, the Common Elder and Privet take possession.

In such woods covert is sought for game, shelter and other ends, and there is no reason why it should not take a beautiful form. No situations about a country house offer such opportunity for beauty as these woodlands, where we can mass and enjoy many of the most beautiful of native and other shrubs for which there is not always room in the garden. They would be far better in the woodland garden than in the usual mixed shrubbery; and while good wholesome undergrowth does not interfere with the trees, but rather helps them, the growth of weeds and Grass rankling over the ground is hurtful in many ways. Some of the finest natural woods have a natural undergrowth of evergreen shrubs, as for instance in the Californian forests with their undergrowth of lovely evergreens, the trees rising with clean stems far above them.

The first aim should be to get rid of the weedy and 
noxious enemies by light grubbing, and then plant in bold free masses things that will fight the weed. I know of nothing that cleans the ground below it more thoroughly than the Red Dogwood; its foliage is so close and it gives bright winter-effect in wet places beside streams and ponds, and will also grow away from water.

Our native Holly, Box, and Yew make much more beautiful and effective groups than the weedy shrubs which usually have possession. The common evergreen Barberry is a beautiful covert shrub, with its foliage all through the winter and its fragrant blooms in spring, but it should be held together in natural masses, and close enough to keep the ground clean. The common way of having coarse Laurels clipped down to one level is ugly, and there are so many things that give a very fine undergrowth without clipping. The large Partridge-berry (Gaultheria Shallon) of North America, as it may be seen at Coolhurst-what an excellent undergrowth it makes, and yet how little grown!

Evergreen Barberries might alternate with our common native Barberry, so brilliant in fruit, and wide masses of Aucuba and Yellow Azaleas, now so easily raised. Such excellent evergreen covert plants as Cunningham's White Rhododendron can be bought on their own roots. Rhododendrons are a host in themselves, but there is too much of the dull ponticum. We should encourage the bright-coloured kinds such as Jacksonii, and never put in a grafted plant. There are splendid kinds in the country if people will only layer them, or even allow them to layer themselves, as they often will when let alone. Kinds good in colour can be picked out in flowering time at the lowest rate the 
nursery trade offers. Only hardy things should be used, and in southern places we may have a little more variety of evergreen undergrowth. Some of the new Bamboos would help very much for effect, such as palmata, which keeps the ground clean and is fine in habit. In open and poor soils the Heaths would tell well, such as the Cornish Heath, and the Common Heather in its stoutest varieties. Sweetbriers, Wild Roses, and Brambles, would naturally be welcomed, and it would be well to encourage native bushes like Viburnum, Sloe, and the beautiful Spindle-tree (Euonymus europaeus), and plants such as Solomon's Seal and the Ferns, which often form a pretty undergrowth in woods. Wherever natural covert exists, as it often does in large woods in the shape of tall evergreen Sedges like Carex paniculata, or masses of Bracken, it should be kept, as there is no better covert.

The planting of covert had better be done from early autumn until March or April, but much may be done throughout the year in clearing the ground and getting rid of weedy plants. That is even better done in summer, as we are then more certain to make an end of them than in winter. When planting Holly in places overrun by rabbits it will be necessary to wire, and if we plant in large, bold masses, as we ought, the wiring is easier. Happily rabbits do not attack Box, which is a great gain when seeking covert for hungry soils or poor dry bluffs. 


\section{CHAPTER XVIII}

FENCING FOR WOODLAND

AN immense amount of energy in our country is given to fencing, which is wholly avoided in some other lands. Our way of keeping stock in the open air instead of in sheds, and the abundance of game destructive to young trees, makes fencing a necessity, and to simplify it as far as may be and to make it enduring is worth thinking about. Many act as if the iron and wire fences were the best-a serious error, as the wood should fence itself, and there are no fencing plants so good as those which grow naturally in woodland, such as Quick. The worst of all are iron and wire fences, which give no shelter, and moreover are ugly and dangerous.

To reduce the extent of fencing. This is one of the motives which should lead us to plant in more visible and natural masses. In the common ring, specimen, and spinney planting there is often more fence visible than plants. No artificial fence that man can invent is half as simple, enduring, easy to keep up, or effective as a Quick hedge set on a turf bank. The cost of this should be less than that of an iron fence. Even in badly-infested places, when we are obliged to use an iron fence to support barbed wire, we should always plant a Quick fence inside it to provide for the future fencing of the wood. The weak point about the Quick fence is that the plants are usually so small that it is expensive to protect them. In many places it would be 
an excellent way to lay down an acre of Quick and let the plants get into a bushy state, and then we should only have to send the cart for stout bushes, which would at once form a fence. I know nothing in woodland work that would be more useful than such a store of Quick. We can buy small Quick everywhere, but it is difficult to get it really strong, and impossible to get the bushes a yard high and nearly as much through, unless we grow it ourselves.

Some years ago I made a fence with old bushy Quick, planting it on the turf bank common in the district; the tough bushes were placed close together and formed a fence at once, but as there were large bullocks nearly always in the pasture on one side, it was thought best to slip a single line of the slender and waste tops from a Larch plantation through the bushes at 2 feet from the ground. The fence made itself at once, and no bullock ever got through or injured it. The expense of fencing the Quick itself was got rid of; an important point if we think of the trouble saved in this way. But to carry out this plan it is essential to put out young Quick and let them grow 3 feet or more high, and the stouter the better. They transplant easily and without risk at any time in autumn or winter.

Simplify the fencing. In planting rough corners of fields running into or near a wood we may often simplify the fencing by taking a short or easy line, so that the fences within the line become useless, and if among these useless fences there is one of Quick which is not very old, it is often well to move the plants to the new fence after cutting them down one-half their height. Having had occasion to move a bank and fence of not very old Quick, I levelled the bank and took the 
plants elsewhere for fencing. The following year the roots of the Quick left in the ground began to come up and make nice little plants, and in another year there was quite a strong line of Quick in the line of the old fence.

The best plants to use. There has been much talk of the Cherry Plum as a fence plant, but it is inferior to Quick in endurance, and in every way. I have much greater faith in some of the American Hawthorns, such as the Scarlet and Cockspur Thorns, which are well armed, tough, sturdy, and fine in colour in autumn. The difficulty is to get a stock of them, as nurserymen are not yet aware of their value, and they are mostly grown for pleasure grounds, and grafted, which means that the native Quick will in time kill the foreigner. I have used some thousands of the Sweetbrier for fencing, and with excellent effect. In one way it is better than Quick, as cattle will not touch it, and creatures of any kind give it a wide berth. A rough woodland fence made of Sweetbrier and Quick, or Cockspur Thorn, is the best possible protection against stock. Barbed wire is not half as fierce as old Sweetbrier, which is impassable to the boldest boy, who would laugh at the idea of barbed wire stopping him.

Let the woodland fence grow freely, and only cut it down every ten years or so; such bold fences are far better in their effect round the woodland than small trim fences, while they may be more effective against stock, and are often as pretty as any garden with wreaths of Honeysuckle, Clematis, and Wild Rose.

Woods without fencing. The needlessness of any kind of fencing in established woodlands is proved by the millions of acres of forest in many parts of middle 
and northern Europe, on mountain or plain, which are without fence of any kind, young or old trees as they come, boldly fringing river, rocky valley, or plain. No stiff or hard lines anywhere; the wood gracing the near land as the clouds grace the sky, while far away the hills massed and crested with Pines show, fold beyond fold, back into the delicate distance, in fine harmony in all lights, but loveliest when the sun bids the woods good night in a sea of golden-purple air. If it be well to be free of living fences of Wild Rose, May, and Holly, how much more the costly iron or wire fence, so ugly in any place where we seek beauty of wood or landscape? This freedom from the ceaseless care and cost of fences is not only for those who plant for beauty, but the men who look to their woods for profit only in doing their work in the simplest way find the palm of beauty too. But this cannot be where the underwood plan is an endless annoyance, with its cutting up of woods and rides, the underwood when cut in recent years remaining in the woods for more than a year after the cutting-a nuisance for various reasons. If we wish to preserve some underwood it is easy to keep it near the centre of the wood, and so dispense with fencing from cattle, or we may even grow it as at present without sacrificing all our woodland scenery and any hope of profit from woodland. Our way in Britain of planting in skinny strips, instead of massing the wood naturally, very much adds to the cost and ugliness of the iron fence, both sides of the narrow strip being often fenced with iron, and on some estates the money spent on this rubbish of iron and wire would suffice to plant all the poor land of a parish.

No hard line. These words are written in a grassy 
glade of about a dozen acres set in the woods of the Bohemian hills. Falling gently to the west it is embosomed in close-set young trees-Spruce, Birch, Scotch and Silver Fir; there is no hard line to be seen; the glade is fringed as it might be in a natural forest. It is as easy to mow as it would be if fenced in the stiffest way, and it could be grazed without danger, as there is no underwood near. The work of the woodman around the glade (and there is a good deal of winter work in woods where tall trees are set close) is far more simple than where, as in many parts of Britain, access to every copse and wood is barred with fencing. For days we pass through such woodland and never see a fence, and when we leave the massed mountain woods, and go into the open plain, with smaller woods here and there, cresting a hill or making the best of a vein of poor land, it is just the same; there is no fence; cattle or men may take shelter or shade; and as the margin of the plantation is often free and varied, the effect is far better than when the wood is held fast within a fence. Certainly many of these are old woods; and when planting in an open country, with cattle grazing on all sides, we cannot hope to get free at once from a great evil; but if we plant only vigorous trees, a few years' good growth will make them safe, and tall trees do not tempt cattle as the shoots of the underwood do. If there be grazing creatures about, why should not the cool shade of the wood be free to them on hot days and its warm shelter on wintry ones, if no harm come from it?

What to do with iron fencing. When our eyes are opened to the ugliness and danger of iron fencing, the question arises as to how it can be turned to account in 
other ways. The danger of wire fencing round pasture fields is evident, and its ugliness appalling in the foreground of fair landscapes. Live fences do away with the need of it in either case, but as there are miles of it in most districts to be got rid of, the best use for it is the protection of young plantations in woods. Most of our country is so infested with ground game that planting is impossible unless we protect the little trees. It is bad enough to lose Scotch Fir, Larch, and the commoner trees, after having had the trouble and cost of planting them, but when it is a question of the rarer trees, often difficult to procure, then we ought to protect thoroughly until they are large enough to take care of themselves. For common trees we may do what is needed with wire only, but there is the danger that with heavy snow it may be jumped by rabbits, or broken down by stock, gamekeepers, and others, and so fail us at a critical time. In choice planting the best way is to surround our plantations with spare iron fencing, and then wire. The most difficult spots to plant are patches in old woods, often of underwood which has ceased to be of any use. Planting choice little trees in such woods is out of the question, so I have fenced with iron an acre of such woodland which had nothing left in it but stubs and a few Birch and other trees of little value. The iron fence is wired $3^{\frac{1}{2}}$ feet high, and within is a plantation of the Western Hemlock Spruce (Abies Mertensiana) and with it a sprinkling of Japanese Larch. This iron fencing is so placed as to be hardly visible from the rides near, and it is always safe against animals and other interlopers. 


\section{CHAPTER XIX}

THINNING WOODS

THis will probably be for many years to come the most important question for the planter. So far English planters have usually taken a view of it wholly distinct from that taken in Germany and France. Our underwoods system and the notion that every fine tree should be set out as a specimen tends to this most unfortunate end. German and French forestry cannot be said to follow any one settled plan, because soils and trees and conditions vary so much that a great variety of woodland enters continental forestry. But one thing is common to all their systems, and that is that the trees stand shoulder to shoulder; and in German forests, in the case of some kinds of trees, we find ourselves in darkness, even on a sunny day, owing to the closeness of the wood. The sun getting into the wood and the rain. absorbing Grass covering the floor of the wood would work havoc, and it is not very different in our country. In those forests not only do we see the trees growing close together and shading and sheltering each other, but other young trees of the kinds that will thrive in shade beneath them in active and beautiful life. The essential idea is to keep the overhead canopy intact, never to let the soil of the wood get dried up, and to keep down the Grass, which always comes if we let our wood get thin. 
There is an error, however, in our planting which ought to be mentioned, and which makes thinning a much more onerous thing, and that is the nursery way of planting trees too closely-e.g. I ft. or $\mathrm{I}_{5} \mathrm{in}$. apart, of which we have seen many examples. In such cases the trees grow so weakly that they never form a good self-supporting stem, and in snow and other storms may be blown over. Where trees are planted in this way thinning is much more onerous, and the same applies when we raise trees from seed in the fields where they are to grow. Trees should never be planted closer than about $4 \mathrm{ft}$. apart. That space allows each little tree to make a sturdy stem and become a useful tree before there is any need to thin. In those countries where thinning is best understood it is only done when the thinnings are useful. Weak or dead trees, or trees overtopped by their more vigorous neighbours, are cut away, but never so that the overhead canopy is interfered with. If the canopy be broken from disease or accident or storm the remedy is to plant young trees beneath which will bear shade. Thus the massed trees remain, and the heads of these are always seeking the light; and thus the mass of rapid lengthening stems is maintained, and the side branches drop off as they decay, leaving strong trees. Thus the Beech, which branches so freely with us, may be seen with clean straight stems $130 \mathrm{ft}$. high. The same result could be easily obtained in our country, where these trees do as well as in the north of France or Germany.

The time of thinning is an important consideration. Generally, thinning is much more active in the early life of trees than in their nearly mature state. When woods of the ordinary Pines of Europe are planted $4 \mathrm{ft}$. apart, 
as they ought to be, there is no need for thinning for, say, fourteen years.

After that time one may take out the beaten trees and the wrong kinds that have got in from seed or otherwise. The first thinning will have little more to do than this, and the wood will not be very valuable, but later on the trees will begin to take some value. It should be remembered that, however we may want a close canopy overhead, each tree must in the end have room to attain its full development. The baby Pine we can hardly see in the Grass will after fifty years or so want its $20 \mathrm{ft}$. in ordinary level land. For though we may see Pines on their native mountains growing closer than this, we have to average the quality of the poor land which trees are so often planted in. We must also think what the trees are grown for, whether firewood, pit-props, masts, or the best class of timber for construction work. Valuable trees like the Oak would be reduced one-half in value by neglect to give them sufficient space to grow in. In Britain generally trees have three times more space allotted them than they need have. 


\section{CHAPTER XX}

GRAFTING AND ITS EFFECTS ON TREES

IN buying a number of Willows some years ago, I was happy enough to find one of unusual grace-a weeping form of the Yellow Willow (Salix vitellina). This Willow is graceful in its habit, but the weeping variety I liked for its exquisite beauty, fine colour throughout the year, and the usefulness of its abundant shoots, which tie like a good twine. I was fortunate in getting several plants on their natural roots, every one of which throve, and in every stage looked well. Then, seeking more, a number were sent me grafted on the Common Ozier, and in the case of these a very different set of circumstances arose. In the first place, you do not get a healthy tree, because the Ozier is not nearly so stately or fine as the Yellow Willow and does not form a good stock. There is a hard and ugly angle between the stiff stem of the stock and the abundant branches of the Yellow Willow. Death begins very soon, and comes in every case, if the shoots are not removed. The appearance of the grafted plants as compared with the other is simply piteous, and the plants are not only worthless, but a nuisance, because after a few years the stocks (of which we have already thousands in the woods everywhere) will become weedy trees out of place. It will at once be seen from this how much is lost by grafting trees in the case of 
Willows. By the labour in removing suckers (which is not likely to be done beside ponds and lakes that are out of the garden) we not only lose our precious tree and its beauty of form everywhere, but we also establish a lot of wretched trees-the very last thing we should want, perhaps-in a beautiful situation. This happened in almost every case of the grafted Willows, so that round my lakes I have a set of dying Willows or Willows arising from the stocks of kinds already dead. All Willows are easily grafted, and some of our finest Willows are usually sent out by the trade from cuttings, and, therefore, are safe; but the moment a Willow has any pretence of being rare, new, or graceful, then, for the sake of increasing it in the cheapest way, it is worked on the Common Withy or Ozier, and every one of the beautiful Willows so worked is sure to be lost. There is not one of these Willows but could be easily increased from cuttings, layers, or seeds. It is very likely that many beautiful Willows have been lost from the practice of grafting; and it is a notable loss, because many of the Willows are among the most beautiful of plants, bushes, and trees we could possibly have beside or near water. The lesson of all this is that people should ask for what they want and refuse to have a grafted Willow on any condition. I have a line on each side of a stream of what is called the American Weeping Willow, a very graceful one. For several years at first they looked distinct and even beautiful; but, in spite of continual repression of the suckers of the Ozier on which they are grafted, these have already got the upper hand, and the once graceful and distinct little line of grey weeping trees is now a hideous funeral procession-at the bottom a thick cloud of half- 
decayed wood and above the Common Ozier, not half as pretty as it is in its natural growth. If our planting were confined to garden planting it might then be possible to control this, but the moment we begin to plant in any right and bold way we must get out of the garden, and watching every tree for suckers is hopeless. A very little trouble would have sufficed to put this graceful Weeping Willow on its natural roots, which would have been a good state for its natural life; but now I not only lose my trees, but have to grub up many Oziers out of place, which is not by any means an easy task.

Among the most beautiful medium-sized trees of the great Rose family are the Thorns; whether for flower, colour, or fruit in autumn, or for their forms, they are very beautiful, and none the less so for their relationship to our common May, though differing from it in their times of flower and in many ways in effect. No trees produce seed more freely than these, but owing to the facility of grafting in nurseries where we buy them they are nearly all put on the common native kinds, on which are also grafted the double and coloured varieties of our own country. Those growing on the parent plant are safe enough, but when we come to graft the various American and Asiatic kinds on the British tree a different result comes about: the native Thorn gradually becomes the master, and instead of a collection of interesting trees we find that we have simply one common kind. There is a difference of season and time of starting the saps, which may be the cause ; but whatever it is, it is a vicious system to put quite hardy trees from countries quite different from ours to grow on other plants. The simple result of doing so is that 
many kinds introduced for many years past are lost to us or rarely seen.

North America was long a rich source of such plants, but apparently there are many more kinds there than was ever suspected to be the case, and it behoves us in the case of the best to always secure them as seedling plants, which certainly cannot be very difficult. Given the natural root, we have the plant as long as we care to grow it. The greater failure, however, arises when great forest Pines of north-western America are grown in any way but from seed. The rare Pines used to be grafted, and this perhaps was excusable when they first came over, but never in the case of any woodland planting. Cuttings are nearly as bad. Owing to the facility of increase of some Cypress-like trees of the Pacific coast of North America, such as Lawson's Cypress and the Giant Thuja, these were frequently grown in nurseries from cuttings, which is probably the cause of the unsatisfactory bushy growth of some of these trees, which, instead of arising as erect stems as in their own country, break out into it may be eight or ten stems on one tree. It is not difficult to get such trees from seed. In any other way they should never be grown. 


\section{CHAPTER XXI}

\section{ENGLISH NAMES FOR TREES}

LORD ANNESLEY's book on his collection of trees and shrubs presents us, as so many books do, with a whole set of Latin names for each tree, no care being taken to find an English name for any of them-not a difficult task. This is merely following the conventional way of botanists, who imagine that all men take the same interest in Latin names as they do themselves, but the facts are the other way. Most people are interested mainly in the beauty and uses of things, and to them names in an unknown tongue are of no meaning and often a source of ridicule. These names may even be used in such a way as to be a bar to knowledge, as is certainly the case in our country. In France and Germany it is otherwise, as their books on garden and woodland work give the native name of each tree or plant, which does not bar the use of the Latin name in its right place. Names are symbols adopted for convenience, and of less importance than the things to which they relate, as is shown by the fact that many people forget names, while retaining a clear memory of things. The multitude of Latin names is an unnecessary obstacle to women and children, and men occupied with outdoor work. On the other hand, good English names often tell a great deal to simple people, e. g. such names as Servian Spruce and Lebanon Cedar. The Latin names are often hideous in structure, 
and often (as scholars tell us) invented by those whose learning is at fault.

There are also numberless false names, like Glyptostrobus and Retinospora - the unfortunate name for the Great Japanese Cypress (C.obtusa), which is still kept up in books and lists. If the true Latin names are confusing, how much more the false and needless ones. Then there is the endless multiplication of varieties with cumbrous Latin names, of which we see an outrageous example in the Kew List of Conifers, pages of which are given to variegated (i. e. diseased) and deformed sports, which are mere garden forms, valueless as trees. If these varieties are kept at all, they are unworthy of Latin names. Another evil resulting from this is that many readers of catalogues take all Latin names as of equal importance. Hence, even in the best conditions, we see distorted and poor forms as often as true trees, and a spotty and bad effect is given to collections, the very opposite of what growers of great trees should expect, and may easily obtain.

A good English name should have precedence of all others for general use. Trees covering vast regions and of high value, like the Western Hemlock Spruce, deserve to be known by English names, which yet are often omitted in books and catalogues dealing with such trees. An Englishman speaking to English people should be able to find in his own tongue names for all things to which he needs to refer. There is no forest tree of Europe, Asia, or America for which a good English name might not be used, and, once generally adopted, we should not then care so much what each succeeding botanist might do towards inventing new Latin names or hunting up old ones. 
Even those who feel the need of English names for garden and woodland things are, perhaps, too apt to assume that the systematic Linnaean name is the only one with any claim to science. But that is clearly an error, as many of our English names are very much older, more interesting, and have been bound up with the history of our people and their language for ages. So that the study of these names may be as much a part of 'science' as any other. The botanical names of the Linnaean system now followed have only been in use during a few generations, and as such they have no more claim to be exclusively 'scientific' than many of the names in our own language. Dr. C. A. Prior, author of a good book on the popular names of British plants, says : 'There are botanists who look upon English names as leading to confusion and a nuisance, and who would gladly abandon them and ignore their existence. But this is surely a mistake, for there will always be ladies and others who, with the greatest zeal for the pursuit of Natural History, have not had the opportunity of learning Greek or Latin, or have forgotten those languages, and who will prefer to call a plant by a name that they can pronounce and recollect. We need but to ask ourselves what success would have attended the exertions of the late excellent and benevolent Professor Henslow among the pupils of his little village school if he had used any names but the popular ones. Besides admitting to the full all that can be urged against them from a purely botanical point of view, we still may derive both pleasure and instruction from tracing them back to their origin, and reading in them the habits and opinions of former ages. In following up such an analysis we soon find that we are entering upon a higher region of literature- 
the history of man's progress and the gradual development of his civilization. Some of the plants that were familiar to our ancestors in central Asia bear with us to this day the very names they bore there, and as distinctly intimate by them the uses to which they were applied, and the degree of culture which prevailed where they were given, as do those of the domestic affinities the various occupations of the primaeval family.'

Those who think that the accepted Latin names of our own day are the only ones with any pretence to 'science' may pause and reflect when they realize the age and use of the name Oak in all northern writings. Thus in early Anglo-Saxon we have $a c$ and $a c$, in Scotch $a i k$, in Old Norse $e i k$, in Swedish $e k$, in Danish and Icelandic eyk, in Low German eek and eik, in German eiche, and in Old High German eih. Our best names are ages older than the Linnaean system, and Linnaeus did one foolish thing in changing the beautiful old name of the Holly (Aquifolium) to Ilex. 


\section{CHAPTER XXII}

NATIONAL AND PUBLIC PARKS AND TREE PLANTING

IN a country like Great Britain, one of the best assets of which is its natural beauty - a thing of value not only to the natives but also to the many visitors who come from the colonies and abroad-it is strange that the question of great national parks has never arisen; the more so seeing that we have the finest opportunities for securing them. Were our country like the plains of the Danube or of Burgundy-levels rich in corn and wine-it would be far less easy; but vast tracts in the British Isles are useless for agriculture or any kind of industry. Stand among the mountains of Wales and see their summits ranging one after the other like the bare rounded masses of great elephants, and without a tree upon them! In Ireland there are beautiful but bare ranges of mountains, often along a lovely seashore, which might easily be secured for all time as national parks. Whatever value they now possess for agriculture, or for any local interest, they would afford in no less degree as national parks, though the best way to treat such places would be to leave them in their natural state. There would be in this very little labour, and certainly no 'laying out' for public parks as we now know them, so prosaic in design and so destructive of beauty. England is richer than Wales, Scotland, or Ireland in agricultural resources and in the value of its land for residential usage, but even so it has vast 


\section{58 National and public parks and tree planting}

areas of natural beauty in its moors and mountain lands in the north and its downs in the south, which might easily be given to this national object.

One of the greatest gains from national parks would be in the opportunity they might afford for planting our native trees in bold masses and forests. These would be massed according to their needs as regards soil and elevation, without any setting out or prim fencing, or any like things usually thought necessary to artificial planting, needless in a national park. In all the more fertile parts and by streams and in valleys these trees would serve the two purposes of showing their natural form and values and of giving a home to woodland creatures.

The only difficulty would be to prevent these great parks from becoming places of public resort merely, which would destroy all the quiet for the creatures we would encourage in them. This could be avoided by selecting spots difficult of access and remote from the busy centres, the woods to be closed at seasons of nesting and breeding, and the merely curious excluded altogether. Anything like formal roads and paths would be avoided, and artists and students might then, under regulation, be allowed access to them. Indeed, the value of such places might almost be considered in relation to their value for artists, as in a thickly peopled country like ours the cultivated and residential land is likely to become more and more inaccessible to them.

In the Nineteenth Century, in his plea for a national park for Scotland, Mr. Charles Stewart enumerated the purposes of such parks as follows :-

(I) The preservation in its wild state of a large tract of country possessing natural beauty, varied in its character and 


\section{National and public parks and tree planting 159}

in its physical features, and combining, if possible, mountain, valley, forest, moorland, lofty peak and rocky glen, greensward and lake, river and burn, sea-cliffs and seashore. (2) The strict preservation in them of specimens of all the indigenous fauna of our country-the red deer, fallow deer, roe deer, hare, badger, otter, wild cat, fox, and the minor quadrupeds, the capercailzie, blackcock, moorfowl, golden eagle, raven, and all the tribe of sea-eagle and sea-hawk, and the lesser native birds and natural fishes. The enclosure once acquired, to be in the words of the Act of Congress when instituting the Yellowstone Park: 'for ever dedicated and set apart as a public park or pleasuring ground.' Mr. Stewart points out that there are estates and stretches of country or islands in Argyll, Inverness, Ross, or Sutherland offering all the charms that could be desired, and fringed by sea, sea-cliffs, and seashore. The island of Jura (about 90,000 acres in extent) or the island of Rum (about 43,000 acres) would either of them make a noble national park. The enclosure should not be less than 20,000 to 30,000 acres in extent, and 50,000 acres would not be excessive. There are deer forests in Scotland which range from 40,000 to 80,000 acres; but even with 10,000 acres, if the ground were sufficiently varied, everything essential for the preservation of big game could be secured. The direct advantages would be the preserving intact of a large and wild tract of country of great natural beauty, and of protecting it for ever from the inroads of the speculator or the schemes of the mining and railway promoter for public use, recreation, and resort, together with the benefit to our food supply, to science, and to pleasure, which would accrue from preserving the wild animals and birds of our country and rescuing them from extinction. The more mountainous and exposed such tracts, the more valuable they would be for showing in bold plantations the alpine and other trees suited for our islands.

London parks. No city has so much varied and beautiful land for public enjoyment, and kept without stint of men or material, as London. The climate is not 


\section{I60 National and public parks and tree planting}

against, but rather in favour of, all hardy trees and shrubs, and the always welcome turf. The smoke of a great city does not affect them so much, and that drawback will surely be got over before many years are past, being a self-inflicted one. We know enough to be able to get rid of the smoke of London in three years if the ' powers that be' would only take it in hand. With these advantages we ought not to lose the good of these parks through inartistic design or stereotyped repetitions of other ways in spite of differences in soil. Nothing could be worse than that these parks should be devoted to a single plan of 'floral decoration' destructive of all initiative on the part of the able men in charge. Nor should they be planted with common nursery trees which one may see by every suburban road. Not that they should be botanic gardens, because we have already the finest existing botanic garden at Kew; but, having such an ample area of space, they might show groups and masses of the finer and rarer trees for which space could not be spared at Kew.

The permanent planting of the whole park should be considered, and we should see something better than broken-backed Elms and the commoner sorts of trees. The Elm, the most dangerous and worst of trees for a town garden or to plant along roads and paths, is too much seen, and often surrounded by spiked rails. If we planted good trees we should have their beauty in the winter-to artists and others a better thing than even a summer effect-instead of wasting our efforts in making a show for a few months in one place only.

Public parks do not afford a tithe of the beauty and interest of which they are capable, if we take into consideration their vast extent, their variety of soil and 


\section{National and public parks and tree planting $\mathrm{I} 6 \mathrm{I}$}

surface, and the large sums spent on their keeping. Everywhere in them we see vast surfaces neglected, or only planted with a few commonplace trees; everywhere evidence that no thought is given to enduring and distinct and artistic planting; everywhere monotony in the materials used. A number of trees become popular, and are planted in about the same proportion, and thus we find the same types of vegetation everywhere, and the capacities of our parks as national gardens are undeveloped.

$A$ suggestion. The plan likely to give us the noblest public parks is to treat all the parks and gardens of a great city as a whole, and to establish as far as possible in each a distinct type of the finer vegetation. We might devote one city park chiefly to deciduous trees; a suburban one like Richmond to evergreen forest trees; another to the almost countless flowering trees and shrubs that are the glory of the grove in all northern countries. Or we might have a square or a park mainly of British trees and shrubs, another of European, another of American, and so on. In such ways we might help the men in charge to more individuality, and free them from paltry rivalry with one another in the matter of 'bedding plants'. They could then take up subjects best suited to the ground, and develop their beauty and variety to the extent of their knowledge. In the vast expanse of our public gardens there is not one interesting branch of tree culture or flower culture which we could not develop in a way hitherto unexampled.

Few of our botanic gardens at present give much idea of the variety and beauty of trees, and none gives any worthy expression of even the vegetation of Europe 
alone! What do we see of the beauty and character of any one large family of trees by planting them all at regular intervals over a plot, or in the various ways we see them arranged in botanic gardens? If our aim be to show the beauty and dignity of the vegetable kingdom, we must set ourselves free from such small notions, and clearly the way to do this is to treat our vast series of gardens as a whole, and stamp on each some marked feature-from the smallest square with Hawthorns, to the great park adorned with the trees of a hundred hills.

In every direction distinct types of vegetation might be met with, instead of the 'universal mixture' now everywhere seen, which so soon trains the eye to take no more notice of trees or plants than of the railings around the squares. It is not, like many of the changes we long for in towns, impossible to carry out from want of means. The adoption of it would tend to make the money freely spent on our public gardens go toward valuable results, and might easily free us from the present way of devoting vast sums to the growth of tender plants. 


\section{CHAPTER XXIII}

\section{HOME LANDSCAPE}

Symmetry certainly owed its origin to vanity and indolence: to vanity, in attempting to force the situation to accord with the building, instead of making the building suit the situation; to idleness, because it was more easy to work upon paper, which will allow of any form, than to examine and combine the real objects.-MARQUIS DE GERARDIN.

Country places being so often in the midst of naturally beautiful scenery, it is all the more deplorable that in so many cases they are so disfigured as to drive away the artist and make sad all who feel the ugliness of the garden and foreground of the house. There are so many hard lines, lifeless gardens, and abominations in iron fencing, destroying all the tender grace of the landscape, and weak, dotty plantings; such crowding out by Cherry Laurels, often clipped to level, hard lines, that the artist runs away from it all and seeks refuge on the nearest common. These and other sources of ugliness are absolutely unnecessary, and this chapter is given to their consideration and avoidance.

Earth puddings. There is a practice in the London parks and elsewhere of raising mounds with the idea of getting better landscape effect, but as generally carried out it is against all good work in landscape gardening. It is assumed by the mound-makers that the ground is not right for their purpose, and so heaps of earth are thrown up here and there to change the form of the 
ground. Any one going through St. James's Park will be able to judge for himself whether anything is gained by this distortion of the surface. It will be clear that at least two things are lost. In the first place, those who made these mounds have rarely any eye for natural gradation, and therefore false lines and stiff banks occur here and there and are very unsightly. Secondly, piling mounds of earth around trees is a sure way of destroying one of the most beautiful aspects of tree life, and that is the way in which the stem arises from the earth, often with a wide-spreading bole, or with a broad buttressed effect. There is scarcely any place where trees grow naturally in which one cannot see the beautiful way in which their stems are built-a form of beauty which should never be concealed by needless earthwork. Such treatment of ground surface is common in France, and some of its worst effects may be seen in the Champs Elysées, which is full of false lines, stiff banks, and beds made at impossible angles, and this poor result is ill concealed by the beauty of the trees and the good planting. In valleys like those of the Thames and the Seine we only lose by altering the natural lie of the ground. There is no planting, either of flower or shrub, that is one whit advanced by the creation of artificial mounds in a valley where the soil is generally good. The art of too many present-day landscape gardeners consists very largely in this artificial chopping and changing of surface, often at great expense and with anything but a gain in effect. It is true that where the ground is naturally broken a slight change in surface may sometimes open up hidden beauty and give better effect, but to create artificial mounds for the mere sake of avoiding a flat surface is a false idea of art. And whenever it is necessary, in grading for walks 
or any other purpose, to change existing surfaces, special care should be taken to avoid this earthing up of tree stems, which not only hides one of their finest features, but is often fatal to certain kinds of trees.

Overplanting of rampant Evergreens. Many places suffer from thoughtless planting of trees in the wrong place as to kind and stature, and ugly overgrowths of all-devouring evergreens, like the Pontic Rhododendron, Conmon Cherry Laurel, Privets, and other nursery rubbish. Few seem to see how much their home landscape is shut out and their pleasure gardens made dismal, and, indeed, sometimes almost uninhabitable, in this way. To those in any doubt about it, the following words by one of the best planters, the late James McNab of the Botanic Garden at Edinburgh, may give courage to think and in due time to act. It is, however, difficult to express in words the harm done to the home landscape by stupid planting abandoned to its own redundance. Apart from these sources of evil, there is the hopeless human one of the man who will not allow a tree to be cut down, no matter how ill placed or how much air or beautiful view it shuts out. This too common type is often quite proud of its doings, and is not to be dealt with by the axe ; it suffers from blindness in not seeing only one side of a very serious artistic question. It is a common thing for even the finest groups and best trees about a country house not to be rightly or well seen, owing to unmeaning trees and coarse shrubs being massed about the house itself, sometimes even to the exclusion of light from the living rooms as well as the landscape beauty of the surrounding country.

When grounds are first planted the trees are small, and the views so extensive that the possibility of these being 
ultimately shut out is never taken into consideration. As time rolls on, many houses become buried amongst a dense forest of trees, and few of the original views are visible, unless one ascends to some eminence. Such shut-up places coming into the market are frequently undisposed of for a length of time, owing to their close and damp nature, the owner never for a moment thinking that such closeness may be avoided. Some often secure such places, and immediately commence a reformation; the charm worked by the woodman's axe, with the aid of the artist or landscape gardener, is often marvellous, and, at a trifling expense, in certain cases the nature of the thinnings paying for the change. The stempruning of a few of the large trees often produces a pleasing effect in giving us views between the stems and beneath the branches. The removal of trees altogether, and the stempruning and branching of others, give views without in the least degree injuring the health of the trees. There is a mansion known to me, on a somewhat rising ground about half a mile from the sea, but shut out from it by large trees and a thicket of evergreen shrubs, where by the removal of some of the under branches of the large and wide-spreading trees, the clearing or thinning out of a few of the evergreens, beautiful views of Inchkeith and the Firth of Forth have been obtained from the windows. At another large house, the removal of an Oak-tree in front of the drawing-room windows has opened up on one side a rich expanse of country, with hills and wooded glens, before scarcely visible. Although these remarks refer to views from houses, they apply also to the wooded banks of rivers, extensive woods, and wooded glens quite remote from dwellings. The eye, when once practised to such landscape effects, will find on many properties numerous spots for such openings.

The usurping Laurel. The late E. W. Cooke, the artist, has a few words about this which cannot be too often repeated:- 'There is no plant perhaps that deserves the title of " usurper" more than what is generally called the Common Laurel. No doubt this fine, free-growing 


\section{Home landscape}

evergreen is one of the most desirable of shrubs when kept in its appropriate place, viz. where it has ample space-under trees on the margins of woods and copses. In accordance with the ordinary ideas of gardening, this shrub is the first obtained from the nursery, as it is also the cheapest, to adorn the approach to the dwelling or the garden at the rear. Placed usually in the very front of the border, and quite close to the walk, it grows most rapidly into a vigorous shrub, its shoots often attaining in a single season 3,4 , or even 5 feet in length. It is impossible to exaggerate the evil of which this rampant shrub has been the cause; the smaller conifers, such as Thujas, Junipers, and Cypresses, as well as Bays, Laurustinus, and Arbutus, are constantly found to be destroyed by its wealth of shoots.'

I have enjoyed the utmost satisfaction in ordering hundreds to be cut down and carted away, thus not only developing to the view many better things, but opening the finest vistas and distant peeps of scenery.

Ring planting. The commonest practice of the planter of our day, in all parks and open spaces, the most precious of all to keep, is dotting about rings fenced with iron. This is the most inartistic thing he can do for effect or the good growth of trees. It gives a dotty, hopeless effect, and is wrong in every way, and most of all for the life of the trees. The mass of trees is not sufficient to give the shelter of the wood or any other of its gains. The fencing is doubly costly because of the small area of the clumps. We should plant in clouds instead of dots, i. e. to mass the planting more in weak corners of fields and where we want shelter, or group them in the way in which they will not spot over the landscape, and the trees will have a chance of attaining woodland 
stateliness, and in which we can form walks agreeable in hot weather and useful in other ways for the creatures or frequenters of woodland.

The browsing line. In pastures this is often very ugly and hard, and few people seem to have the courage to get rid of it-by no means a difficult matter. We should always remember that trees grow in the forest as columns, not bushes, and the isolation of a tree in pasture, by causing it to branch all round, gives it often a shape far from beautiful, and by allowing the cows to do the pruning we do not improve matters. It is bad in another way by overweighting the tree with branches, because many of these lower limbs the tree itself tries to throw off as they become feeble and worn out. The right thing to do in many such cases is to remove the browsing line by trimming up as far as the true framework of the tree, which often begins Io or more feet above the 'line'. In many cases I have cut away the branches to a height of I5 feet, and a more free and good form has been obtained.

Toy tray trees.-An acquaintance with the Pine woods of the northern world should save us from the weak way of planting each tree, set out by itself as a 'specimen'. Even worse is it when, instead of keeping these Pines in the pinetum, they are scattered about the foreground of the house, and some of the finest houses in England are marred by scattering Pine-trees in the foreground. The conical shape of many Pines, always ugly as compared with the trees of our own country, is only natural to them when young. Of the many questions which the landscape planter has to face that of the forms and grouping of trees is the most important. A knowledge of them is absolutely needed in pleasure grounds, parks, and woods; not only the ordinary plantation or shrub- 
bery of the country, but also in long-established woods. This knowledge is not only essential for good planting, but also from an artistic point of view. Nor must it be confined to one aspect only of even our few native trees. Take the Oak : how mistaken any one might be as to its planting who knew only one expression of its beauty! The Oaks in the country south of London are quite distinct in aspect from those of Warwickshire. Yet the Oak, set close in a Sussex wood, with many silvery columns rising out of Primroses, is as beautiful as any of the fine Oak growths of the Shakespeare country. And this is but one example of the variation of habit of one tree, showing the need for the study of trees in nature, and not only in books. If we travel in mountainous lands where Pines abound, we find that they grow close together, that the 'extinguisher' is not their true form, and that they shoot up into handsome stems, often over roo feet high without a branch. It is a delusion to suppose that there is anything old or right about the common set out mode of planting conifers, as most of them are recent gains to our country.

Iron fencing. Nothing tends to mar the beauty of the foregrounds of landscape so much as the use of iron fencing, a modern practice, and easily avoided in the garden or near it. This is so important that a previous chapter is given to it as regards woodland. All that has been'said of it there is equally true of the home landscape or wherever we have to deal with fences.

Dismal Avenues. The making of narrow airless avenues was so common in the past that the landscape in many places is marred and barred by avenues too narrow and too close-set, the effect of which is to cut off good views, and in wet or gloomy weather to give 
a feeling of depression, all the worse when we go to parts of our islands blessed with a very heavy rainfall. There are handsome and airy avenues which do not hide the landscape from view, but avenues as most commonly seen are not always wisely formed and would be often better away. Where the drive is broad and the margins are free on both sides, with the trees in groups as at Powis, the effect is much better. If there is not the space and conditions to plant avenues well it is best to have none, and this applies to such places especially. Good examples of avenues rightly made are to be seen at Dalkeith, Powis, Heythrop, and other places in England and France.

As to the trees to plant in avenues, the best is usually the native tree. I have seen some picturesque avenues of Scotch Fir, but the Californian Pines we cannot trust for this purpose. When avenues of Araucaria or of Wellingtonia have been tried they are failures, and the avenue plan is against the successful culture of these trees. Among Elms for avenues the best is the Mountain Elm, which is less dangerous than the Common Elm. The Plane also makes a noble avenue tree. Beech does very well occasionally, but is apt to be blown over when old.

Cedars of Lebanon are the grandest of all exotic trees for an avenue, but there should be plenty of room and a picturesque position for the best effect to be made of this noble tree.

A beautiful and picturesque avenue may be made where the drive going towards the house runs through woodland of varied trees. Here the effect of an avenue is gained without doing hurt to the landscape, and shelter and shade and all the gains of an avenue 


\section{Home landscape}

can be had without the drawbacks of what I have called the 'dismal avenue'. If the trees are grouped and massed with some variety all the better; but in this sort of avenue two mistakes are commonly made: the first is cutting the face of the wood into hard lines. Very often the edges of woods where avenues of this kind are made are planted with rampant evergreen shrubsLaurel, Yew, Box, and Pontic Rhododendron. The growth of such things after a few years is much more rapid than people expect when planting them, and they push out into the drive and obscure the air, light, and shade. Many have not the courage to cut them right out, but cut them back into hard, ugly, stiff lines instead, which often conceals the beauty of the wood and cuts off its light and shade and even air. Such planting should be avoided as a border to the wood. The dignity and stature of the trees that fringe the woodland avenue should be clearly seen; if possible there should be a good Grass margin, and in wet districts the trees should never be allowed to overshadow the drive. We gain nothing by letting rank evergreens encroach on the avenue, but in case we have them so encroaching our proper course is to cut them away altogether. A group of Box or Yew on a sandy knoll looks well from a distance, but no good effect is got from things of this kind encroaching on a drive. An attempt is sometimes made to form a stiff line of trees along a woodland drive-it may be Wellingtonia, Lombardy Poplar, or any other trees. Any attempt at making a sort of avenue effect in front of a wood is rarely successful, and is not nearly so pretty as allowing the wood to show its best effects of silvery stems of Birches or great groups of Oaks, Ash, or Scotch Firs. 


\section{N D E X}

Abies amabilis, 47 .

- concolor, 46.

- grandis, 44 .

- lasiocarpa, 46 .

- Lowiana, 46.

- nobilis, 33,44 .

- Nordmanniana, 44 .

- Parsonsiana, 46.

- Sitchensis, 42.

Acer dasycarpum, 125.

Alder, I28.

Arbor-Vitae, the Giant, 43.

- - Western, IIo.

Art in relation to flower-gardening and garden design, $\mathbf{} 6$.

- talk of the day about, I4.

'Artistic', the term, 20.

Artists in planting, I8.

Ash, the, 57, 126.

Aspen, IIO.

Avenues, dismal, 169.

Azaleas, I29.

Bamboo, Japanese, 92.

- the palmate, 92 .

Bambusa falcata, 92 .

- Metake, 92.

- palmata, 92.

Barberry, Evergreen, 89.

Basswood, гзо.

Beech, 56, 126.

Berberis aquifolium, 89.

Betula lutea, 128.

Birch, 72, 127.

- Canoe, 127.
Birch, European, 127.

- Paper, 127.

- Yellow, 128.

Box, 8 .

Bracken, I24.

Brier, 124.

Broom, native, 86.

- Portuguese, 88.

- Spanish, 88.

Brooms, the, 85 .

Browsing line, 168.

Buckeye, I28.

Carex paniculata, 139.

Carpet-beds, things of our own time, patterns of flowers and, 3 .

Cedar, Canoe, 42.

- Deodar, 37.

- Red, 45.

Cedars of Lebanon and Atlas, the, 4I.

Cedrus atlantica, $4 \mathrm{I}$.

Chestnut, 66.

- Horse, 128.

Choice essential, 18.

Clipping back, no, Io6.

Cornus sericea, I29.

- stolonifera, 129.

Covert, evergreen, 88.

- from seed, wood and, 82.

- plant, a beautiful evergreen, 92.

- sowing direct, 83 .

Crataegus, 127. 
Cupressus Lawsoniana, 4I.

- nootkatensis, 42.

- obtusa, 42.

Cypress, Bald, 74.

- Great Japanese, 42.

- Lawsons, 4r.

Cytisus albus, 86.

- scoparius, 86.

Degradation of flowers, I9.

Design, 38.

- garden, and recent writings upon it, $\mathrm{I}$.

- Art in relation to flowergardening and, 38 .

- Waterworks, 13 .

Distinctions, false, 34 .

Dogwood, 124, I29.

Down planting, I20.

- Mountain and Hill and, II6.

Draining, I3I.

Earth puddings, 163 .

Elm Field, 69.

- Wych or Mountain, 68.

Euonymus europeus, I30.

- latifolius, 1зо.

- Thunbergianus, rзo.

Evergreens, overplanting rampant, 165 .

Failure, a source of, 3I.

Fencing for Woodland, 140.

- Iron, I69.

- - what to do with, I44.

- no hard line in, I43.

- simplify the, $\mathrm{r} 4 \mathrm{I}$.

- the best plants to use, I42.

- to reduce the extent of, I4O.

- woods without, I42.

Fields, tail ends of, 29.
Fir, Cascade Mountains, 47.

- Columbian, 33, 44.

- Crimean, 44 .

- Douglas, 42.

- Puget Sound, 44 .

- Silver, 43.

- White, 46 .

Firs, close planted, 35 .

Flower-garden near the house, 5 .

- - the true test of a, 8.

- - the Wild garden does not take the place of, 4 .

- gardeningand garden design, Art in relation to, $\mathbf{I} 6$.

Flowers, degradation of, 19 .

Forest, Northern, the greater evergreen trees. of the, 36 .

- - summer-leafing trees of the, 50 .

Foxbrush, 85.

Fraxinus lentiscifolia, 126.

- Mariesi, 126.

- Oregona, I26.

- pennsylvanica, I26.

- rhyncophylla, 126 .

Fuel, 26.

Furze, dwarf, 85 .

Garden design, and recent writings upon it, $\mathbf{I}$.

- - Art in relation to flowergardening and, 16.

- - W aterworks, 13 .

- flower, near the house, 5 .

- - the true test of $a, 8$.

- ways, loss of, 3 .

- Wild, does not take the place of the flower-garden, 4 .

- Woodland, the, 137 .

Gardening, Landscape, 7.

Gardens, Landscape painting and, 2 r. 
Gardens, variety the true source of beauty in, Io.

Gaultheria Shallon, ${ }_{3} 8$.

Ginkgo biloba, 72.

- tree, 128.

Gorse, I24.

Grafting and its effect on trees, I49.

Growth, quickness of, 25.

Guelder Rose, I24, I29.

Hazel, I24.

Hedges, and shelters of Holly, 94 .

Hemlock Spruce, 45.

- - the Western, 45 .

Hickories, 130.

- and Walnuts, 76.

Hill and Down planting, Mountain and, 116.

Holly-hedges, and shelters of, 94 .

Home Landscape, 163.

Hornbeam, 67.

Horse Chestnut, I28.

Idealism, realism and, I7.

Iron fencing, 169.

- what to do with, I44.

Ivy, Poison, I27.

Juniperus Sabina, 90.

Land, planting poor, 24 .

Landscape gardening, 7 .

- Home, I63.

- painting and gardens, 2I.

Landslips, trees on ground liable to, I20.

Larch, 59, 130.

- Japanese, rзo.

Laurel, the usurping, $\mathbf{} 66$.

Lime, American, 130 .

- Silver, тзо.

Limes, 130 .

Liquidambar styraciflua, Iзо.
Liriodendron tulipiferum, $\mathbf{3} 3$.

Locust tree, 65 .

Maidenhair tree, 72.

Maple, the Sycamore, 70.

Maples, 125.

Moorland planting, high, II7.

Mountain and Hill and Down planting, II6.

Names for trees, English, 153 .

Nyssa, 126.

Oak, common, $5 \mathrm{I}$.

- Durmast, 54 .

- Evergreen, II4.

- varieties, and synonyms of the, 54 .

Oaks, I24.

Osier, 109.

Painting, Landscape, and gardens, 2 r.

Parks, a suggestion, I6I.

- and tree planting, national and public, 157 .

- London, 159.

Parrotia, I29.

Patterns of flowers and carpetbeds things of our own time, 3 .

Picea alba, 48.

- canadensis, 48.

- pungens, 43 .

Pine, Austrian, 40.

- Bhotan, 47.

- Corsican, 38.

- Jeffreys, 46.

- Monterey, 40.

- Scotch, 39.

- stem, the beauty of the, 33 .

- Swiss, 40.

- White, 39

- Yellow, 45. 
Pinetum, a true, 27.

Pinus Cembra, 40.

- excelsa, 47.

- insignis, 40.

- Jeffreyi, 46.

- Morinda, 47.

- orientalis, 39 .

- pinaster, 39 .

- polita, 47.

- ponderosa, 45 .

- Smithiana, 47.

Plane, Eastern, 64.

Plant, where to, 27.

Planting, artists in, I8.

- avoidable waste in, r3r.

- be ready in, $\mathbf{3} 35$.

- Down, I20.

- Mountain and Hill and, II6.

- mixed, I5o.

- Moorland, high, II7.

- permanent, I6o.

- poor land, 24 .

- ring, 167 .

- Shore-lands, II2.

- time of, 3 r.

- tree, national and public parks and, I57.

- Waterside, ro7.

Plants, use little, 30.

Poison Ivy, I27.

Poplar, I26.

- black, IIo.

- grey, Iro.

- Lombardy, 64, 1 Io.

- White, 63, rro.

Populus trichocarpa, 126.

Pterocarya, гзо.

Quercus tinctoria, I24.

Realism and Idealism, I7. Rhododendrons, 88.
Rhus cotinoides, I27.

- glabra, 127.

- Osbecki, I27.

-- succedanea, I27.

- typhina, r27.

Rides, Woodland, ro3.

- - forming, Io2.

Rose, Guelder, I24, I29.

- Wild, I24.

Salix fragilis, 62, Io9.

— viminalis, rog.

- vitellina, rog.

- pendula, rog.

Savin, 9o.

Sea Buckthorn, II5.

Seed, wood and covert from, 82 .

Sequoia gigantea, 48.

Shade, woodland, I05.

Shelter, 24.

Shelters of Holly, hedges and, 94.

Shore-lands planting, II2.

Site, any way good that best suits the, I2.

Snowy Mespilus, r29.

Soil-makers, trees as, I33.

Spartium junceum, 85 .

Spindle tree, r3o.

Spruce, Caucasian, 46.

- Hemlock, 45.

- - Western, 45.

- Norway, 43.

- Rocky Mountain, 43.

-. Sitka, 42.

- Tiger tail, 47 .

- White, 48.

Sumach, Stag's-horn, I27.

- Venetian, I27.

Sunny spots in woods, ro3.

Sweet Gum, rзo.

Sycamore Maple, 70. 
Taxus, 4I.

Terms, misuse of, 5 .

Thorn, I27.

- Cockspur, 127.

Thuiopsis borealis, 42.

Thuja gigantea, 43 .

- Lobbi, 44.

Time of planting, $3 \mathbf{r}$.

Tree, Big, the, 48.

- Ginkgo, 128.

- Locust, 65.

- Maidenhair, 72.

- planting, national and public parks and, ${ }_{57}$.

- Spindle, זзо.

- Tulip, 75, гзо.

- Tupelo, I26.

- Willows, 79.

- - for effect, ro8.

Trees as soil-makers, $\mathbf{1 3 3}$.

- best for our islands, native and European, 77.

- English names for, ${ }_{53}$.

- for beauty, 8o.

- grafting and its effect on, I49.

- on ground liable to landslip, I20.

- the greater evergreen of the Northern Forest, 36.

- - summer-leafing of the Northern Fores, 50 .

- toy tray, 168.

- useless evergreen, 37 .

Trenching, I32.

Tsuga canadensis, 45 .

- Mertensiana, 45.

Tupelo tree, 126.

Ulex nanus, 85 .

- strictus, 85 .

Underplanting, 96.

Variety essential, II.
Variety, the true source of bèauty in gardens, 10.

Viburnum, I24.

Vines, 128.

Virginian Creeper, I28.

Vitis Coignetiae, 128.

- Thunbergi, I28.

Walnuts, 130.

- Hickories and, 76.

- Winged, rzo.

Water, a danger of, III.

Waterside planting, ro7.

Waterworks, garden design, I3.

Wild garden does not take the place of the flower-garden, 4 .

Willow, Bedford, rog.

- Cardinal, Iog.

- Crack, 62.

- Red, rog.

— White, 6o, Iog.

- Yellow, rog.

Willows, I25.

- Tree, 79.

- - for effect, Io8.

Withy, $\mathrm{r}_{50}$.

Wood and covert from seed, 82 .

- value, 78.

Woodland, fencing for, I4O.

- fine in colour, I23.

- garden, the, 137 .

- rides, I03.

- - forming, Io2.

- shade, I05.

Woods, evergreen, for beauty, 24 .

- Home, 23.

- on mixed, 99.

- sunny spots in, Io3.

- thinning, $\mathrm{I} 46$.

- without fencing, I $_{42}$.

Yew, common, the, 4I. 

ins mparmol

THIS BOOK IS DUE ON THE LAST DATE STAMPED BELOW

AN INITIAL FINE OF 25 CENTS WILL BE ASSESSED FOR FAILURE TO RETURN THIS BOOK ON THE DATE DUE. THE PENALTY WILL INCREASE TO 50 CENTS ON THE FOURTH DAY AND TO \$1.00 ON THE SEVENTH DAY OVERDUE.

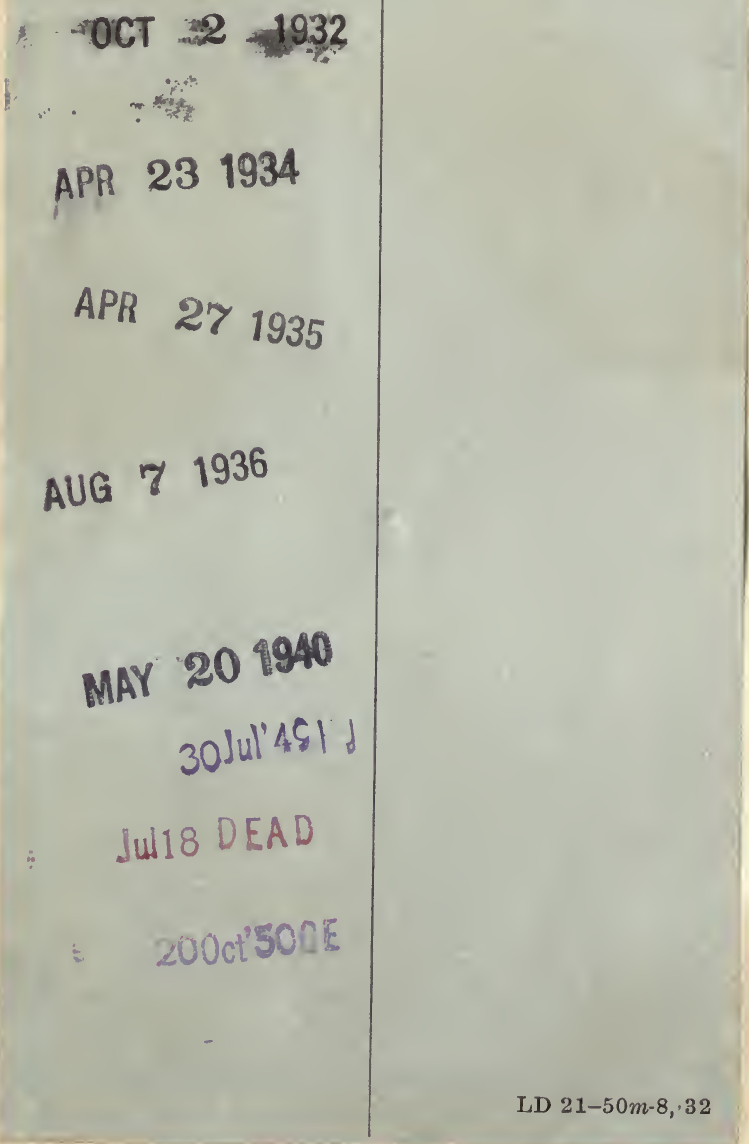




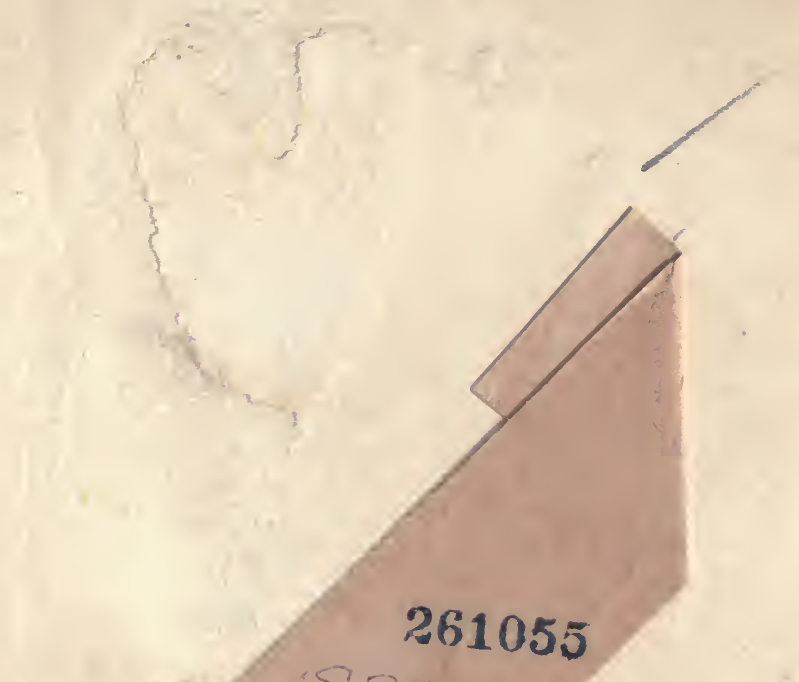

$$
\frac{S E+72}{156}
$$


